\title{
Is good governance priced? An examination of listed firms from OECD equity markets
}

\section{Introduction}

The outward governance structure of firms provides a strong indication of the incentives shaping internal managerial decision-making and strategic orientation with respect to the attraction and retention of minority outside investors. In this way the adoption of costly governance provisions designed to enhance and protect the property rights of minority owners reduces their agency-related bonding costs from participating in the firm's ownership structure (Jensen and Meckling, 1976). The consequent reduction of risks associated with residual claims facilitates their ease of transaction and exchange, where this in turn supports active external markets for these capital claims (Jensen and Meckling, 1976; Fama, 1980). Thus, the outward governance structure of firms provides a strong indication of the revealed preferences towards expropriation by incumbent insiders and owners with voting rights in excess of their cash flow ownership who typically have effective control over the corporation.

However, firms alone do not influence their bonding costs with outside investors, and it is necessary to take into account wider state-level investor protection in the form of quality institutions underpinning the external contracting environment. The relative strength or quality of external contracting environment critically determines the effectiveness of governance provisions at firm-level (Doidge et al., 2007; Gompers, Ishii and Metrick, 2003). The institutional environment not only provides ease of access to regulatory contractual enforcement mechanisms such as legal and judicial systems, but also to more normative notions of industry-level corporate governance "best practice" that act as a substitute for deficiencies in formal legal contracting as well as professional accounting and auditing associations that underscore effective reporting standards. Transparency through stringent accounting standards is only as effective as the quality of national reporting systems which themselves are contingent on state-level institutional quality. For example, a firm may be unable to commit to credible external verification of its income disclosures if the necessary infrastructure for such verification is either not available or is lacking in effectiveness (Doidge et al., 2007). In this way, the macro-level institutional environment determines the effectiveness of external capital markets in facilitating investors ability to exchange residual risk claims in any given firm (Jensen and Mecking, 1976). 
Consequently, in countries with weaker state investor protection, capital markets will be less developed and more inactive, implying that firm's will be motivated less to adopt costly external governance provisions in shaping their outward governance structure. Thus, there will be less reliance on external capital infusions and comparatively greater reliance on controlling block shareholders and incumbent insiders with control rights in excess of their cash flow entitlements (La Porta, Lopez-deSilanes, Shleifer and Vishny, 2002). Conversely, in countries with higher institutional quality, firms are more focussed on raising capital from external minority investors and thereby more prone to adopting the Berle and Means (1932) separation of ownership from control through diversified ownership model of governance. Therefore, they will be more motivated to adopt costly governance provisions in order to reduce outside investor bonding costs and thereby reap the benefits associated with raising external finance on more cost effective terms. As such, country-level institutional quality determines the quality of protections afforded to supporting the external contracting environment, and thus determines the benefits accruing to firms adopting more costly governance provisions in their outward structure. In this way, we argue that state-level institutional quality and firm-level governance are complementary - where if it were costless for firms to adopt governance provisions then all would do so, but in environments shaped by differing institutional quality, the costs and subsequent benefits accruing to firms adopting costly measures varies significantly.

We build on the premise of the seminal work of Gompers et al (2003) that firm's outward governance provisions can be categorized as either supporting democratic notions of one-share onevote and enhancement of minority protections, as opposed to dictatorial with these enhancing incumbent insiders and controlling block entities who have voting rights in excess of cash flow entitlements. Furthermore, given the inherent difficulties in measuring expropriation, the outward governance structure - be this more democratic or dictatorial - provides an indication of revealed preferences towards expropriation by insider groups. We argue that in a long horizon model, on balance or in aggregate, the costs associated with expropriation by insider groups will be borne by minority outside owners. This will impact on their welfare. Thus, firms adopting outwardly democratic governance structures are more motivated to extract fewer private benefits of control and thereby better protect the property rights of minority investors as compared to those adopting dictatorial governance provisions.

In this paper, our first contribution is in creating a unique index of 45 outward governance provisions where each is designated as either "democracy" or "dictatorship" in terms of the protection afforded to minority investor rights vis-à-vis dominant insiders or controlling block owners. This draws on the ASSET4 governance database of firm-level provisions, disseminated by Thomson 
Datastream alongside regular trading data. Furthermore, it extends the Gompers et al (2003) notion of firm-level governance through a bespoke "G-index" incorporating 24 distinct outward provisions adopted by firms. It yields a considerably clearer picture of the governance of firms as compared to the 6 governance provisions in the "anti-director rights" index developed by La Porta et al (1998) or the limited coverage in Credit Lyonnais Securities Asia (henceforth CLSA) governance universe where 495 firms drawn from across 25 emerging markets and 18 sectors (see Klapper and Love, 2004). We draw on the blue-chip index constituent lists of 35 OECD national equity markets where in the UK this also includes FTSE100 (large cap stocks) as well as FTSE250 (mid cap stocks) and in US it includes constituents of S\&P1,500 in the form of S\&P500 (large cap stocks), S\&P400 (mid cap stocks) and S\&P600 (small cap stocks). This amounts to a universe of 4,714 stocks, where 2,984 of these are also included in the ASSET4 governance universe. Firm's included in the ASSET4 universe have governance parameters estimated annually based on their annual reports.

Our second contribution extends the intuition of the Gompers et al (2003) study of a trading strategy based on exploiting weak (dictatorial) versus strong (democratic) governed firms to produce abnormal profits during period 1990-1999. This has further been elaborated by Bebchuck, Cohen and Ferrell (2009) where they subsequently found only six of these governance provisions - formed into a distinct "E-index" - generated abnormal profits. We argue that outward governance differences are an effective proxy for expropriation tendencies by insider controlling groups and block owners - where these will impact minority investor welfare in the long run. We also incorporate country level institutional quality, to capture the quality of external contracting environment, in the form of an equally weighted average of the six World Governance measures (see Kaufman et al., 2009). We propose a new stock returns governance-based measure formed from cross product of firm's individual governance indices and country-level institutional quality that captures the dynamics of relative firm governance and country institutional quality as well as the complementarity between the two. We extend the Gompers et al (2003) arguments of pricing anomalies caused by governance in proposing a new returns-based valuation factor to be included into a two-factor capital asset pricing model alongside the market factor.

Our empirical findings reveal systematic variations in investor welfare in relation to our new governance valuation factor across deciles ranked on basis of governance quality or the degree of democracy as opposed to dictatorship. Stocks in higher democratic deciles attract a discount, while those in less democratic and more dictatorial deciles attract a premium. These findings are robust across the OECD overall universe as well as sub-universes formed on OECD equity markets omitting the US and the US only universe. This latter distinction between sub-universes is important since in 
the US only case the distinguishing characteristic between individual firms is the governance index itself, while in the multi-country OECD excluding US universe, national institutional quality must also be taken into account. Our findings are also robust to changes in the institutional quality measurement through our additional employment of "Legal Structure and Security of Property Rights Index" developed by Gwartney and Lawson (2007), which focusses on the legal security of property rights for minorities. Finally, our proposed two-factor CAPM augmented by the new governance valuation factor outperforms comparable asset pricing models based on liquidity (Liu, 2006), ownership-based investor protection (Hearn et al, 2017), the size and book-to-market factors of Fama and French (1993) three factor model, henceforth FF3F, and the four-factor extension of this including momentum of Carhart (1997).

We proceed as follows: Section 2 focusses on the development of our governance index, the construction of its associated governance valuation metric and theoretical propositions linking governance to investor welfare. Section 3 describes data while section 4 addresses valuation factor construction and comparative performance and descriptive statistics. Section 5 outlines our empirical results while section 6 details robustness tests. The final section concludes.

\section{Firm governance}

\subsection{Firm-level governance index}

Prior literature on the construction of governance indices has fallen into two areas: the first being on indices capturing governance-related elements of national legal codes that apply to firms within that jurisdiction, while the second focusses on variation in individual firm's governance structure. The first adopts survey or questionnaire methods in codifying national legal code responses to governance clauses. This emanated from the pioneering "anti-director rights" index of La Porta et al (1998) which captured six dimensions of shareholder protection defined within prevailing national legal code statutes. These broadly cover two areas of property rights: the first three are concerned with shareholder voting, with these focussing on voting by mail and proxy, voting without blocking of shares, and ability to call an extraordinary meeting, while the second three are related to minority protection and address proportional board representation, pre-emptive rights and judicial remedies ${ }^{1}$. The dataset was drawn from 49 national legal codes as well as the ownership structure of the five largest publicly traded private (non-state) non-financial firms. More recent innovations to this have

\footnotetext{
${ }^{1}$ La Porta et al (2000) defines the six index dimensions as (1) the permissibility of proxy voting, (2) deposit of shares prior to general shareholders meeting, (3) cumulative voting or proportional representation of minorities on board of directors, (4) an oppressed minorities mechanism is in place, (5) whether the minimum percentage of share capital ownership to call an extraordinary shareholders meeting is less than or equal to ten percent, and (6) when shareholders have pre-emptive rights that can only be waived by a shareholders meeting
} 
included Djankov, La Porta, Lopez-de-Silanes and Schleifer's (2008) anti self-dealing index, constructed from questionnaire responses of 102 "Lex Mundi" law firms in 72 countries worldwide, and broken down into sub-indices representing ex-ante and ex-post private control of self-dealing. Spamann (2010) introduced a revised version of the original "anti-director rights" index which also drew on questionnaire appraisal of national commercial codes by local lawyers as the source of primary data for a revised governance index.

The second, more firm-related strand of governance index literature, has developed from the inaugural contribution by Gompers et al (2003) and the introduction of a governance " $\mathrm{G}$ " index covering a total of 24 provisions with 22 of these drawn from individual firm's bylaws, charters, annual reports and US SEC listing filings and a further 2 drawn from state-level commercial code legal provisions. The sample here drew on constituent firms of US equity market's S\&P500 index, and the annual lists of largest corporations in the publications of Fortune, Forbes and Businessweek that were also covered in the detailed listings of corporate governance provision published by Investor Responsibility Research Centre (IRRC). These were extracted for years 1990, 1993, 1995 and 1998 inclusive. This itself has been revised by Bebchuck, Cohen and Ferrell (2009) with an "E" index comprised of 6 of the original 24 elements that were found to significantly drive empirical performance results.

Our new index draws on the comprehensive Thomson Reuters ASSET4-ESG database of governance attributes of individual listed firms worldwide (see Thomson Reuters ESG Scores, $2017^{2}$ ). This was fully integrated into the Thomson Datastream platform in 2009 along with backdated data from its inception in 2002. In this way, it is seamlessly integrated with trading data which are more typically associated with the formation of valuation factors used in asset pricing models. ASSET4ESG uses data drawn from individual listed firm's annual reports to populate three distinct categories of organizational structure: (1) environmental, (2) social and (3) governance. The third, namely "governance", encompasses structural parameters relating to three thematic categories, namely (a) management, (b) shareholders and (c) CSR strategy. Collectively categories (1) environmental and (2) social, alongside the third dimension (c) or CSR strategy of third category (3) relating to governance form the basis of the Environmental and Corporate Social Responsibility characteristics reported in the ASSET4-ESG database. However, our new governance index is comprised solely from elements drawn from third category (3) governance, and specifically the thematic dimensions (a)

\footnotetext{
2 Thomson Reuters ESG Scores, 2017 refers to full overview of ESG scores and definition of structural elements and parameters - sourced from website financial.thomsonreuters.com/esg
} 
management, and (b) shareholders which forms the core of the governance theme of ASSET4-ESG database.

At this stage it is worth noting that despite the unique and extensive coverage of the ASSET4ESG database, that firstly this has significantly grown over time since inception in 2002 where the overwhelming majority of coverage was limited to largest blue-chip firms in US, Western European and Swiss equity markets. There are annual significant jumps or increases in the coverage of the ASSET4 database with one of the largest of these being during period 2007-2009. However, even by September 2017 the coverage of emerging economies was minimal where this is exemplified by approximately 170 Chinese and 100 Indian firms where these are two of the largest emerging economies worldwide. This largely justifies our focus on a sample of constituent firms from OECD equity markets as opposed to the much broader sample of MSCI world equity markets. Secondly the maintenance and current availability of individual structural and/or governance elements varies considerably from firm to firm. Consequently, while there are almost 300 structural and governance elements per firm included in the ASSET4-ESG database, there is marked variability in current maintained data availability across constituent firms. As such this further reduces the sample to 86 structural-related attributes that are consistently maintained and populated with data. However, of these only 45 are strictly focussed on "governance" elements which are coded as "Yes"/ "No" or "Y/N" responses, as opposed to various numerical values. Thus, our final sample is comprised of 45 binary elements covering firm's outward governance structure.

These are outlined in Table 1 where they are further subdivided into four thematic groups with these being minority rights, voting, delay, and director incentives. The minority rights group includes 16 provisions relating to underlying board of directors' composition as well as individual director liability. The former addresses issues relating to minority property rights in terms of representation on board and the selection or nomination of directors to board as well as their ability to provide effective monitoring and surveillance over corporate affairs and executive decision-making. The latter focusses on entrenchment issues and legal liability of individual directors in relation to their decisions and breaches of fiduciary responsibility while in office. The voting group is comprised of 16 provisions relating to the protection of minority shareholder voting rights. These focus on the centrality of oneshare one-vote as opposed to different classes of share and infringements of control rights in relation to cash flow entitlements, confidentiality of voting and ability to vote by proxy and motions such as supermajority and written consent. The delay group includes 6 provisions designed to slow down a hostile takeover. The market for corporate control is the ultimate disciplinary recourse in the Jensen and Meckling (1976) agency-theoretic view of firm. These six provisions relate to significant reforms 
to director tenure inhibiting potential changes following a takeover, as well as the firm's ownership control structure being enmeshed within extensive cross-shareholding networks - such as Japanese keiretsu or business groups. It also covers golden shares with preferential "veto" rights, and unlimited restriction on authorized capital of firm where incumbent insiders effectively have a blank check with which to fight off hostile bidders' accumulation of voting shares. Finally, the director incentives group includes 7 provisions relating to shareholders having uninhibited say on insider director's self-reward tendencies in the form of compensation structure and levels of pay. It also addresses the effectiveness of compensation committee and compensation policy design.

Collectively the four thematic groups containing the 45 governance provisions reflect the internal monitoring and incentive structures used to align controlling insider interests with those of minority outsider shareholder owners. However, they also capture the ultimate disciplinary function of the market for corporate control which externally reinforces the governance system through constant evaluation of incumbent firms.

\section{Table 1}

The formation of the new governance index adopts an equally weighted sum of all 45 governance elements. Each element that is coded as a "Yes"/ "No" or "Y/N" response is then binary coded with value 1 for those elements enhancing democracy governance and 0 otherwise, and in the cases of those elements enhancing dictatorship governance a value of 0 for those "Y" values and value of 1 for corresponding " $\mathrm{N}$ " values. Missing values are omitted from being coded as either 1 or 0 and thereby not included in the resulting index. It should be noted that while we include more governance elements than in the Gompers study, these are included on the basis of availability in the ASSET4 database. This construction follows that of the Gompers study in attributing the binary value of 1 to governance elements deemed to enhance minority shareholder rights which are termed as "democracy" elements as opposed to those that detract from these and empower incumbent insider groups and block owners, where these in turn are termed "dictatorship" elements. However, a distinctive attribute of our new governance index is that it draws on extensive international coverage and not just availability within the US which is a visible constraint in studies introducing firm-level governance indices such as Gompers et al (2003) and Bebchuck et al (2009).

We construct an annual time series of the new firm-level index, where index values are reevaluated annually alongside the annual frequency of updating of all elements in ASSET4-ESG universe. However, we adopt the forward-fill method used in both Gompers and Bebchuck studies in carrying forward the individual firm index values from the last reported date of 2016 into 2017. 
Mindful of the inception of ASSET4-ESG in 2002 and we also adopt a variant of this and assume those index values prevalent in 2002 are unchanged going backwards for preceding years 2001 and 2000. This is justified owing to the relative rigidity of firm-level governance changes over short periods of time, such as up to 2 years. Importantly it facilitates later comparison between the governance-related portfolios and valuation factor with all other factors estimated over full length of sample period.

The percentage proportion of firms adopting each of the 45 governance provisions that form the basis of our index in year 2015 are reported in Table 2. This draws on sub-samples of our overall OECD sample of 3,244 firms' constituent to 35 national blue-chip stock exchange indices (see Appendix A, Table 1A), where 1,912 are also covered in ASSET4 governance dataset for year 2015. We break this down to compare governance attributes of firms' constituent to the large, mid and small cap US indices - namely S\&P500, S\&P400 and S\&P600, and then contrast firms with their primary listing locations falling between civil code law as opposed to common law jurisdictions. Differences between civil code and common law jurisdiction firms are immediately obvious with "democracy" governance provisions generally being markedly more prominent in the latter legal regime as opposed to the former. This is exemplified by board diversity policy where over $77 \%$ of common law firms report adherence as compared to just over $25 \%$ of civil code law firms. This pattern is repeated across all governance elements between the two legal systems underscoring the differences in protection of minority investor property rights afforded by each system. This evidence is very similar to that documented in La Porta et al $(1998,2000)$ which contrasted differences between civil code and common law in terms of national legal governance code provisions. Finally, a clear distinction is visible across US blue chip indices from S\&P 500 through S\&P 400 to the small cap S\&P 600. This last category of firm has the weakest governance protections in terms of adoption of democratic governance attributes. This is anticipated on the basis of smaller, less well capitalized SME firms in

S\&P 600 index being less able to afford the adoption of costly governance provisions in contrast to their better capitalized and larger blue-chip counterparts in S\&P 500. It also signals a clear association between firm size, outward governance structure and the importance of external finance as originally highlighted in La Porta et al (2000).

\section{Table 2}

\subsection{Governance measure}

The final governance metric is the result of the multiplication of underlying individual firm governance index and country-level institutional quality. This is beneficial in its simplicity - where a 
tie-breaker is given in sorting stocks that are well-governed but can be distinguished in the relative protection afforded to minority shareholders by prevailing national legal and dispute-resolution systems. The governance measure is defined as:

$$
\text { Governance }_{i j t}=(\text { Institutional Quality })_{j t} *(\text { Governance Index })_{i j t}
$$

for country $i$ at year $t$ and Governance Index is the yearly index value for each listed firm $j$.

Institutional quality is formed from the average of the six World Bank governance indicators: control of corruption, government effectiveness, political stability and absence of violence/terrorism, regulatory quality, rule of law and democratic voice, and accountability (Kaufman et al, 2009). ${ }^{3}$ These indicators range from -2.5 to +2.5 but here have been rescaled to take a value between $0-10$. Country $i$ refers to the primary listing location of firm $j$. We adopt the country of primary listing as opposed to the country of incorporation on the basis of the "legal bonding" hypothesis of Coffee $(1999,2002)$ and Charitou et al (2007). Firms incorporated in an overseas jurisdiction adopt or "legally bond" to the governance arrangements of the country of their primary listing. The governance indicators were first reported in 1996 and were updated at two yearly intervals until 2002, after which they were produced annually. In the early years of the series, the indicators in the intermediate year were assumed to be the same as in the preceding one, given the relatively slow nature of institutional change (Williamson, 2000, 2002; North, 1991, 1994). However, drawing on literature such as Klapper and Love (2004) and Chen, Chen and Wei (2009), and one potential shortfall is in the attribution of well governed firms scoring highly on individual firm governance index but are situated in poorly governed national contexts with weak institutional quality. It is important to state that we assume the complementarity of firm-level governance attributes and national institutional quality as opposed to their being substitutes. The complementarity assumption has far reaching implications - where national institutions are deemed essential to support deep capital markets through their facilitation of external third-party contracting, which enable firms to take advantage of these sources of external funds through their adoption of governance. This mitigates minority investor adverse selection through being better able to gauge relative quality of investment opportunities in residual risk claims, as well as recourse to effective institutional sanctions acting as a deterrent to deviations in moral hazard following investment.

\subsection{Relationship between institutions and firm governance}

\footnotetext{
3 The six indicators are recalculated and updated every two years and were calculated back to 1999. Source: http://info.worldbank.org/governance/wgi/index.asp. See Appendix B Table 1B for definitions.
} 
The theoretical basis for our proposition of minority investor welfare differences in relation to governance are based on the premise that differences in the outward governance structure of firms yield pervasive pricing anomalies in the long run equilibrium economy that cannot be simply arbitraged away given they fundamentally relate or proxy an underlying state variable.

While classical efficient market theory (e.g. Fama, 1970) questions whether public information can ever be used to produce abnormal returns, adaptive efficient market theory (e.g. Daniel and Titman, 1999) suggests the ability of any trading strategy based on public information to generate riskadjusted abnormal profits will dissipate over time. Developing from this basis, Bebchuck et al (2013) argue that market traders effectively "learn" the differences between good and bad governance and incorporate these into arbitrage order flow that adjusts prices in equilibrium. However, these approaches are centred on the notion of rationality in the form of expectations and related behaviours. In contrast, we argue that investors are not fully rational, where this is exemplified in the documented "home bias" in equity portfolio investment based on trading strategies encompassing markets and listed firms that are institutionally compatible with investor's home equity market. This more institutional shaping of investor preferences incorporates greater degree of persistence in differing reactions towards differences in governance than is otherwise assumed by Schleifer and Vishny's (1997) "limited arbitrage" which argues that information is slowly incorporated into traded prices over longer time horizons.

Our theoretical model assumes perfectly integrated asset markets that are subject to mild segmentation reflective of differences in corporate control. This extends the restricted CAPM model of Errunza and Losq (1985) and Merton (1987) and follows the intuition developed in Heinkel et al (2001) in considering the asset pricing implications arising from a subset of investors emerging from within a given universe. Further, we assume that at any given time there is a finite number of listed firms and a finite pool of investors. Following Giannetti and Koskinen (2010), two categories of investors are considered: minority portfolio investors and controlling shareholders. This leads to an assumption of a natural difference arising between the outward governance structure of any given firm - where this is either dictatorship or democracy orientated. The former acts to empower insider groups and controlling shareholders, while the latter empowers dispersed minority outside investors. Following La Porta et al (2000) and Giannetti and Koskinen (2010), we argue that there are two payoffs arising from shares. The first is attributable to all security holders in the form of dividends and capital gains, while the second is preferential access to private benefits that accrue only to controlling block shareholders. 
Thus, firms with dictatorship governance structures are attractive solely to controlling shareholders who compete to acquire full control over firms through large block shareholdings. Conversely, firms with democratic governance structures have widely dispersed investor bases with few, if any, block holdings. We argue that national institutional quality is complementary to firm governance structure as it supports external capital markets for residual risk claims - but in turn these are representative of the market for corporate control. This is supported by Klapper and Love (2004), who find that average firm level governance is lower in countries with weaker legal systems. Therefore, governance within the firm is correlated with contractual imperfections and levels of asymmetric information in their national environment. We also follow North (1991, 1994), who claims that the institutional development within a given society, or country, is a function of the continuous interaction between firm transactions, the ruling polity and the wider population and this acts as a check or balance to the moral authority of the state. In this way the internal governance of the firm is inextricably linked to the external institutional quality by the nature of the political economy.

As noted above, at the centre of our model is the assumption of perfectly integrated capital markets that are mildly segmented by restrictions in corporate control. Thus, controlling shareholders exert their control through larger block ownership holdings in firms with weak governance (and more dictatorial in nature) - situations that also exhibit greater information asymmetry. Here, the expropriation of private benefits motivates their participation as these augment otherwise low riskadjusted returns associated with such dictatorially-governed firms.

Our model focusses on the welfare implications for minority portfolio investors arising from the need to diversify by optimising portfolios that draw on a wide cross section of stocks from weak (dictatorship) to strong (democracy) governed firms. Given the mild segmentation assumption, arbitrage trading to close price differentials is impeded, reflecting the laws of supply and demand (Errunza and Losq, 1985; Heinkel et al, 2001). In this way, more dictatorial governed stocks attract controlling shareholders due to the relative ease of extraction of private benefits in an environment of informational asymmetry and opacity in financial reporting and governance practices. Such controlling shareholders dominate ownership of firms through large block holdings and consequently minimal free floats are available for minority portfolio investors. However, the limited supply is offset by a lack of demand by minority portfolio investors given they face the risk of expropriation. Thus, the stock price decreases in equilibrium to reflect the risks associated with informational asymmetry and increased expropriation risk. Therefore, minority portfolio investors demand higher expected returns to compensate for this lower price and this is reflected in a positive premium. Conversely, in firms operating in an environment with high institutional quality, the ownership base is formed from widely 
dispersed minority portfolio investors and an absence of controlling blocks. The absence of controlling block shareholders implies a reduction in entrenchment and expropriation risk, while higher institutional quality implies greater protection of property rights for minority investors. Thus, the demand for these shares is greater and the price is driven up. The enhanced price is a reflection of a discount because of the lower risk and therefore expected return.

Our model considers a continuum of investor protection, ranging from weak to strong, following Giannetti and Koskinen (2010). However, we implicitly consider a notional average level where minority investors expect a premium when participating in dictatorship-orientated governed stocks and a discount when participating in their democratically-governed counterparts. These differences lead us to anticipate a persistent difference in the cross section of stock returns, attributable to institutional quality and outward governance structure.

Despite literature evidence relating to the formation of governance indices, for example the Gompers et al (2003) "G-index" or Bebchuck et al (2009) "E-index", and their linkage with abnormal profits associated with governance-based trading strategies exploiting differences between weak and strongly governed firms, this has not been extended into a formal asset pricing framework. The study by Gompers et al (2003), ${ }^{4}$ is seminal inasmuch that they created a governance index and used stateand firm-level governance to rank a universe of US firms into decile portfolios ranging from the weakest governance, or dictatorship portfolio, to the strongest, or democracy portfolio. The market universe is taken from the Investor Responsibility Research Centre (IRRC) and includes approximately 1,500 stocks, which account for over 93\% of capitalization of the New York stock exchange (NYSE), the American stock exchange (AMEX) and Nasdaq. These ten governance-ranked decile portfolios were used in an application of the Carhart et al (1997) four factor augmented-CAPM pricing model. This is the standard CAPM augmented by size and book-to-market factors (Fama and French, 1993) plus the momentum factor. Un-priced premiums, the alphas, were found across all deciles, and those associated with the lowest and the highest governance quality deciles were statistically significant. The application of the Carhart et al (1997) four factor model to a zero-cost portfolio, which reflects a structure of buying firms in the weakest governance category and selling in the highest, resulted in annualized abnormal returns of $8.5 \%$. The Gompers study also found that firms with stronger shareholder rights had higher value, higher profits, higher sales growth and lower capital expenditures, all consistent with La Porta et al (2000, 2002). An advance on this study was that undertaken by

\footnotetext{
${ }^{4}$ Albuquerue and Wang (2008) develop a dynamic stochastic general equilibrium model to study the association between asset pricing and the welfare implications of imperfect investor protection. They find that countries with weaker investor protection attract larger risk premia, greater return volatility, lower Tobin's q and higher interest rates. This is in line with our theoretical model.
} 
Bebchuck et al (2009) where findings revealed that six of the 24 governance provisions used in the preceding Gompers study drove the earlier results. However, despite finding evidence of a premium, no asset pricing application was proposed. This literature forms the basis of our first proposition:

Proposition 1: Welfare losses arising from diversification between weak (dictatorship) and strong (democracy) governed firms are reflected in a premium

Theoretically, we argue that our view of firm governance is based on varying transaction costs that impact on the property rights of minority investors seeking diversification across a mildly segmented but otherwise perfectly integrated market universe. While we link systematic changes in corporate control rights using institutional quality and comparable outward governance attributes to diversification premia and the cross section of stock returns, our measure is most closely associated with both the ownership-based investor protection measure recently introduced by Hearn et al (2017) and a liquidity effect. The investor protection measure explicitly considers differences between block shareholders and diversified minorities in terms of relative ability to appropriate firm assets. However, liquidity provides an alternative measure of transaction costs that vary systematically across the cross section of stock returns. Further to traditional approaches, such as Goyenko et al (2009), Lesmond (2005), and Hearn (2014), which contrast various liquidity metrics in capturing transaction costs, we adopt the multidimensional measure of Liu (2006). This combines a modified turnover ratio measured in terms of volume traded, with the proportion of daily zero trading volume days per month, to measure trading speed. This provides a multidimensional focus of transaction costs and improves on the limitations of more singular volume-based or simple price-impact measures, while also capturing a dimension of trading frequency. Thus, liquidity provides an obvious stock-ranking metric based on transaction costs, which are influenced by institutional quality, market microstructure and corporate governance (Bewley, 2002; O'Hara, 2003). However, the transaction costs captured are, by nature, external and do not reflect the governance of the firm, where this is reflective of revealed intentions towards expropriation of minority outsiders, which is at the heart of our new investor protection measure.

Other factors commonly used to explain the cross section of stock returns are in Fama and French (1993), that is additional premiums attributable to persistent differences in size and accounting book to market value of stocks. Size premium in particular relates to small market capitalization firms that persistently underperform in terms of earnings during and following wider financial and economic downturns than larger firms (Fama and French, 1993). Accounting book to market value captures 
differences across the cross section in terms of underlying value, with high ratio firms less costly but with higher intrinsic value stocks while the opposite is true for low ratio firms. Fama and French (1993) proposed a three factor CAPM model with size and book to market value factors in addition to the simple market factor. Carhart et al (1997) extended this by adding a momentum factor on top of the underlying Fama and French (1993) model to create a four-factor version. Momentum relies on the past returns performance of stocks with a premium attributed to differences in the cross section of stock returns between low and high performing stocks (Jegadeesh and Titman, 1993, 2001). However, a shortcoming is that size, book to market and momentum factors are based on fundamentals and performance and ignores any consideration of transaction costs, where these are most likely the source of any deviation. Thus, we propose the following:

Proposition 2: Governance is more robust in capturing the cross section of stock returns than investor protection, liquidity, momentum, accounting book to market value or size measures

We perform a number of procedures to test the above propositions. Firstly, we disaggregate the OECD overall universe into two components: a OECD excluding US universe and the US as a single country. The selection of the US only universe is based on it being comprised by the large S\&P1,500 constituents who are universally covered in ASSET4 database and the importance of including a single equity market where national institutional quality becomes superfluous and firms are solely ranked in accordance to their firm-level governance index. The OECD excluding US universe facilitates comparison across a heterogeneous multi-country mix of national institutional regimes based on civil code law variants and common law while omitting the single largest common law market - namely the US. There are also notable differences in control structure - where cross-shareholding networks are virtually absent and family ownership is minimal in the US case while both are prominent across the rest of OECD member states. Notably in the US a far greater proportion of firms adhere to dispersed ownership model than in OECD counterparts. This distinction based on universe classification facilitates tests of the above propositions and provide an additional context for the asset pricing models. Secondly, we test our new investor protection metric by formulating a returns-based factor in a simple two-factor augmented CAPM framework and compare the performance of this with FF3F, Carhart 4F (including momentum), and Liquidity-augmented two-factor models for each of the four universes. We also compare monthly-rebalancing and annual-rebalancing factor portfolio construction techniques with different valuation factors. Additionally, we relax the time invariant parameter assumptions of the traditional CAPM framework and adopt the Kalman filter approach to the FF3F, 
Carhart 4F (including momentum), Liquidity 2F, and Investor Protection 2F models and compare the performance of each. This yields a robust method of evaluating factor performance in explaining the cross section of stock returns.

Finally, we test the robustness of our results by using an alternative proxy for institutional quality, the "Legal Structure and Security of Property Rights Index" developed by Gwartney and Lawson (2007), which focusses on the legal security of property rights for minorities. Our results are on the whole robust.

\section{Data and summary statistics}

\subsection{Sample selection}

Our sample is constructed in two stages. The first sorts all markets within the OECD 5 and uses La Porta et al (2000)'s distinction between those with national jurisdictions that are either common law or civil code law. The second selects stock-level data from the major blue-chip index constituent lists in Datastream (see Appendix A, Table 1A). This criterion ensures they conform to international investors' selection requirements in terms of marketability and accessibility (foreign ownership restrictions). It also avoids the problem of selection bias that can arise from pre-determined minimum price criteria, as found in Hou et al (2011). The blue-chip index constituent stocks also conform to international asset diversification assumptions regarding inter-market asset market integration that is essential to the CAPM, and thus avoids intra-market segmentation prevalent in emerging stock markets.

The data are from January 2000 to September 2017, although ASSET4 data is only available from January 2001 onwards. This is relatively short but reflects the period for which governance data was compiled by ASSET4-ESG. The data includes single class ordinary shares only and excludes preference shares, dual class shares, warrants, convertibles, REITs, closed-end funds, exchange traded funds and depository receipts. Finally, where any return above $300 \%$ that is reversed within one month is treated as missing, that is, if $\mathrm{R}_{\mathrm{t}}$ or $\mathrm{R}_{\mathrm{t}-1}$ is greater than $300 \%$, and $\left(1+\mathrm{R}_{\mathrm{t}}\right) *\left(1+\mathrm{R}_{\mathrm{t}-1}\right)-1<50 \%$, then both $\mathrm{R}_{\mathrm{t}}$ and $\mathrm{R}_{\mathrm{t}-1}$ are set to missing. This follows Ince and Porter (2003).

Following Hou et al (2011), we ensure accounting ratios are known before returns and thus match the end of year financial statement data for year t-1 with monthly returns from July of year t to June of year $t+1$. We use the inverse of the market-to-book-ratio (see Appendix B, Table 1B) to calculate the Book to Market Value ratios. In addition, size is defined as the market value of equity at the end of June of year $t$, while momentum (Mom) for month $t$ is the cumulative return from month $t-$

\footnotetext{
${ }^{5}$ OECD members are from: http://www.oecd.org/about/membersandpartners/list-oecd-member-countries.htm
} 
6 to month $\mathrm{t}-2$, skipping month $\mathrm{t}-1$ to avoid microstructure biases such as bid-ask bounce or nonsynchronous trading.

The final sample consists of 4,714 common stocks from the 35 OECD equity markets blue chip indices. However, 2,984 common stocks are covered by the ASSET4 database in terms of governance data availability. Our sample comprises the S\&P 1,500 index constituents for US only, alongside a total of 3,214 stocks across the remainder of OECD. Figure 1 shows the distribution of the sample over period January 2000 to September 2017. US stocks contribute 34\% of the total OECD universe alone, while Canada contributes 5\%, UK and Australia \& New Zealand both contribute 7\%, Japan 12\%, Scandinavia 9\% and Western Europe 16\%. The rest are from Eastern Europe, Middle East and Latin America. Figures 2 and 3 reveal the development of the sample over time - with the former showing the overall sample, while the latter shows the ASSET4 constituent sample. It is immediately obvious that the ASSET4 coverage has greatly increased since 2002 and that increases occur in distinct annual "step increases" reflecting the frequency of reporting of governance parameters from published annual reports and increased coverage of listed firms across sample markets.

Figures 1, 2 and 3

\subsection{Summary statistics}

Table 3 reports the summary statistics for the new governance measure, its underlying firm governance index, alongside a comparison of the investor protection measure, its underlying percentage proportion of free float and country-level institutional quality. The last three columns report market capitalization (in US\$), accounting book to market value ratio and the liquidity metric of Liu (2006). The 35 OECD countries are grouped into regional categories with Europe being divided between developed and emerging using the MSCI classification system. Finally, using the definition by La Porta et al (2000), countries are classified into civil code as opposed to common law jurisdictions. A number of observations can be noted. First, English common law nations are associated with higher institutional quality compared to the majority of civil code countries, reflecting the work of La Porta et al (1999, 2000).

There is considerable variation in the governance metric with this being highest for US S\&P 500 constituent firms and lowest for Mexican and Turkish blue-chip index constituent firms. However, it is highest for the common law countries of US (2,242 for S\&P 500, 2,193 for S\&P 400, and 2,117 for S\&P 600), Canada (2,174), UK (2,206 for FTSE 100 and 2,014 for FTSE 250), Ireland $(2,119)$, Australia $(2,164)$ and New Zealand $(2,067)$ as well as civil code law Netherlands $(2,145)$. 
Contrastingly it is lowest for Latin America with Mexico (645) and Chile (1,015), Middle East with Turkey (757) and Israel $(1,192)$ and Asia with Japan (1,011) and South Korea (803). However, the low values of these last two Asian countries is in contrast to their rankings under the investor protection measure where both rate very highly. We argue that the new governance measure captures underlying differences in cultural aptitude of firm's towards adopting democratically orientated governance provisions. This is particularly true in Japan and South Korea where there are extensive cross-shareholding networks such as keiretsu and chaebol structures present and national culture is based on communitarian or communalistic norms as opposed to more individualistic norms present in European and North American cultures. This is indicative of a propensity towards extended relational contracting as opposed to external contracting that is typical of European and North American countries. The new governance metric captures this deeper cultural phenomenon reflected in firm's decisions to structure their outward governance structure. Mean firm size is generally higher in US, Canada and Western Europe than other world regions. This ranges from US\$ 16.55 billion in US S\&P500 firms, US\$ 25.89 billion in UK FTSE100 firms, US\$ 187.62 billion in Ireland and US\$ 112.51 billion in Netherlands to US\$ 0.29 billion in Iceland and US\$ 0.14 billion in Estonia. It is notable that there is a markedly lower variation in book to market value across the sample. However, there is considerable variation in liquidity levels, measured by Liu (2006) metric, with these being noticeably higher in the less developed equity markets of Eastern Europe and Scandinavia.

\section{Table 3}

\section{Factors driving returns}

\subsection{The construction of Factor Mimicking Portfolios (FMPs)}

To study the influence of factors, such as size, book to market value, momentum and liquidity on the variation of world stock returns, we follow Fama and French (1993), Liu (2006) and Hou et al (2011) and construct returns-based proxies using zero-investment portfolios. These portfolios go long in stocks with high values of a given characteristic and short in stocks with low values for that characteristic. We use the time-series regressions of Black, Jensen and Scholes (1972), following Fama and French (1993) and more recently Liu (2006), to assess the pricing implications arising from the liquidity metric. In this approach, the excess returns on test portfolios are regressed on the returns of FMPs. The time series slopes are interpreted as factor loadings that inform how various combinations of these FMPs explain the average returns across the portfolios. We form market portfolios based on both equal and value weighted returns of all stocks within a universe at a given time and use the yield on the 10 year US Treasury bill as our risk free rate. 
We use size and book to market value (Fama and French, 1993), momentum (Jegadeesh and Titman, 1993) and liquidity (Liu, 2006) to form the FMPs using two different techniques. The first creates 25 quintile portfolios using a two-stage sorting process. The stocks are sorted into five portfolios based on size, and then sorted again by book to market value. At any time, those with missing values for either characteristic are omitted, as are stocks with negative book to market values. FMPs relating to size are created from average returns on small size portfolios minus those on big size portfolios (SMB factor) and similarly with high book to market value portfolios minus low book to market portfolios (HML factor). Portfolio rebalancing takes place annually in June, following Fama and French (1993) and Hou et al (2011). SMB and HML factors are formed from value-weighted returns.

Construction of the momentum and liquidity FMPs are slightly different. These use 10 decile portfolios with stocks ranked on momentum across portfolios, where momentum is defined as the cumulative return over the preceding six months, and on liquidity, defined as in Liu (2006). The FMP for momentum follows the Jegadeesh and Titman (1993) six-month/six-month strategy, where monthly returns are an equally weighted average of six individual strategies of buying the winning decile portfolio and selling the losing decile portfolio. Rebalancing occurs monthly. ${ }^{6}$ In order to minimize the bid-ask bounce effect, we skip one month between ranking and holding periods when constructing the momentum FMP. This FMP is formed from equal-weighted returns.

The liquidity FMP is created by first ranking stocks by their Liu (2006) liquidity metrics. These are sorted into 10 decile portfolios and the FMP formed from returns difference between high illiquidity decile portfolios and low illiquidity decile portfolios. Then, two FMPs are created based on the frequency of rebalancing. The first is rebalanced annually in December, following Fama and French (1993). The second is rebalanced monthly with the FMP returns formed from the averages across each of twelve annually held liquidity FMPs, similar to the method used for the momentum portfolio in Jegadeesh and Titman (1993) ${ }^{7}$. This was also used as a robustness check in Liu (2006).

The FMP based on the investor protection measure introduced by Hearn et al (2017) is created by ranking stocks by their individual investor protection metric. Ranking is by the prior month and year. The ranked stocks are then sorted by each period and then put into 10 decile portfolios with the investor protection FMP created from returns difference between low investor protection decile portfolios and high investor protection decile portfolios. In common with the liquidity portfolios, two

\footnotetext{
${ }^{6}$ That is, the momentum FMP return for January 2001 is $1 / 6$ of the return spread between the winners and losers from July - November 2000, 1/6 of the return spread between winners and losers from June - October 2000, etc.

${ }^{7}$ That is, this liquidity FMP return for January 2005 is formed from 1/12 of the return spread between high liquidity ranked stocks and low liquidity ranked stocks for January 2003 - January 2004, 1/12 of return spread between high and low liquidity stocks for February 2003 through February 2004, etc.
} 
investor protection FMPs are formed based on the frequency of rebalancing. The first is an annual rebalancing in December of each year, following Fama and French (1993), and with an annual holding period. The second is a monthly rebalancing, with annual holding periods. The resulting FMP returns are created from the averages across each of twelve annually held investor protection FMPs, similar to the method used for the liquidity FMPs.

Finally, the FMP based on the new governance measure follows the procedure outlined above for the investor protection based FMP. However, it only uses annual as opposed to monthly rebalancing in line with both governance and institutional quality being measured annually. Higher governance deciles reflect firms strategically adopting democracy-enhancing governance provisions that facilitate external contracting and lower bonding costs otherwise incurred by minority outside investors. This captures both firms in high quality institutional environments that are typically common law jurisdictions as well as firms in low quality institutional jurisdictions that voluntarily adopt more democratic governance elements in order to competitively attract foreign portfolio investment. In this way the new governance measure captures the strategic intentions of the firm in terms of the degree of adoption of external democratic governance tenets. This is based on the relative importance to individual firms of reducing bonding costs incurred by minority investors.

\subsection{Descriptive statistics of Factor Mimicking Portfolios}

Table 4 reports the means, standard deviations, autocorrelations and cross-correlations of monthly returns of the FMPs for the entire sample. The market portfolio has an average excess return of $1.12 \%$ over the 201 month horizon in the OECD overall universe (panel 1) which is statistically significant (t stat 3.23). We select the equal-weighted market portfolio. This has an approximately normal distribution, according to the Jarque-Bera statistic rather than the value-weighted market portfolios,

which are highly non-normal. The difference in distribution between these two returns series is also reflected in the levels of kurtosis and skewness. These results are not reported but are available from the authors on request.

FMP's relating to size (SMB) and liquidity also have large mean returns that are equally statistically significant (panel 1). Mean returns on SMB are 1.86\% (t stat 7.33) for OECD overall universe. In the case of liquidity and mean returns are $-1.13 \%$ ( $t$ stat -4.56 ). SMB has low kurtosis, skewness and largely conforms to Normal probability distribution, however, this is in contrast to liquidity where Jarque-Bera statistics reveal substantial non-normality in returns.

It is worth noting that of all the FMP's, those attributable to HML and Momentum are smallest in average returns -under $0.50 \%$. This implies that HML and Momentum are largely relevant in 
explaining the cross section of stock returns in the US context and are less useful in other equity markets worldwide. This implies that if premiums do exist for each of these factors they are likely to be smaller in absolute size.

Finally, the FMPs associated with investor protection and the new governance measure are generally small in terms of average returns -under $0.50 \%$, while the governance FMP returns are statistically significant across all three universes and the investor protection is only significant in OECD overall and US universes. Finally, it should be noted that the governance FMP mean returns conform to normality the most of any of our FMPs in terms of skewness, kurtosis and Jarque-Bera statistics across all three universes.

It should be noted that we have not reported the monthly rebalancing FMP results for brevity, although these are available from authors upon request. Monthly rebalanced FMPs for liquidity and investor protection are highly correlated with their annually rebalanced counterparts leading to our omission of these monthly liquidity and investor protection FMPs. Therefore, the factors included in the time series asset pricing tests are the equally weighted market excess returns, the value-weighted size and book-to-market FMPs, the equal-weighted momentum FMP, and the annually-rebalanced equal-weighted liquidity and investor protection FMPs.

In terms of correlations (see Table 2, panel 2) it can be observed that correlations are very low (under 0.50) in absolute value between all FMPs and the FMP's and market portfolio. However, it is notable that despite the low absolute size, correlations are statistically significant amongst the market portfolio, SMB, HML, liquidity and momentum FMPs - while this significance is largely lacking between both the investor protection and governance FMPs and any of the others. Finally, concerns regarding autocorrelations are mitigated due to their low absolute size and negligible statistical significance over 1, 6, and 12 month lagged periods. (Table 2, panel 3).

\section{Table 4}

\subsection{Descriptive Statistics of Governance Portfolios}

Table 5 panel 1 reports the characteristics of the stocks for the overall universe in each of the ten decile governance portfolios with respect to geographical region and legal origin. It shows clear trends across all decile portfolios in terms of the country of primary listing. In common with La Porta et al (1998, 2000) we find that the highest governance deciles are dominated by stocks from English common law markets, while the lowest are dominated by German, and to a lesser extent French, civil code stocks. The propensity of German civil code law stocks in lowest governance deciles is largely due to Japanese and South Korean stocks minimal democratic governance structure - where these 
stocks form sizeable proportions of our underlying ASSET4 sample. Unlike La Porta et al (1998), we find that Scandinavian civil code stocks are more closely associated with English common law and exhibit a dramatically increasing trend towards higher governance deciles. This suggests a similar level of minority investor protection in Scandinavian civil code and English common law countries.

When we separate stocks by regional location of their primary listing venue, these trends are accentuated. Stocks from Australia and North America overwhelmingly populate the highest governance deciles (D5 to D10) with minimal, if any, participation in lower governance deciles (D4 to D1). Developed Europe and Scandinavian stocks are more evenly distributed across all governance deciles - although there is a notable increasing tend towards higher governance deciles. Conversely stocks drawn from Asia, notably Japan and South Korea, are almost universally located in lowest governance deciles - between D4 and D1. This unexpected finding further underscores a marked departure from their comparatively high ranking in terms of investor protection metric and in particular their levels of free float capitalization. Finally, stocks drawn from Latin America, Emerging Europe and Middle East are almost all universally located in lowest deciles - which is a largely anticipated result owing to the weaker institutional environments in these regions and minimal minority investor protection.

Finally, in Table 5, panel 2 we separate stocks in the US only universe across the three subcomponents of the S\&P 1,500 US equity market index - namely large cap S\&P 500, mid cap S\&P 400 and small cap S\&P 600. There is a clear trend in stocks constituent to S\&P 500 blue chip index in the highest governance deciles, while increasing trends in opposite direction are true of stocks constituent to S\&P 400 and S\&P 600 indices - where these dominate the lowest governance deciles. This evidence implies a distinct size effect where smaller firms that are less capitalized are less able to afford to implement costly outward governance structures.

\section{Table 5}

The summary statistics for firm characteristics for the ten investor protection decile portfolios are also reported in Table 5, with the overall universe in panel 3 and the US only universe in panel 4. These support the existence of a governance premium between firms with high as opposed to low governance. First, the evidence from returns is not so strong with mean returns being lower on lowest governance decile (D1) than the highest (D10) where this is only marginally statistically significant in the equal weighted case $(p \leq 0.10)$. Second, and the strongest evidence arises from the highly statistically significant $(p \leq 0.005)$ differences between lowest and highest governance deciles across all other variables with the sole exception of momentum. This is true across both universes - namely 
OECD overall and US only. Liquidity is lower, reflected in a higher Liu (2006) illiquidity metric, in D1 than in D10, while traded volume, book-to-market value ratio, proportion of free float capitalization and investor protection metric is lower in D1 than in D10. This is also true of the firmlevel governance index and the new governance metric - both of which are lower in D1 than the highest decile, D10.

A notable exception to the trend of lower value variables in D10 to those in D10 is the proportion of daily zero price-returns where this is reflective of increased informational efficiency in terms of investor preferences shaped by information being crystallized into elevated order flows. This is then reflected in more movements in stock price and hence decreased price rigidity or proportion of daily zero returns. This is an unanticipated finding since it would be expected price rigidity would be in line with the multi-dimensional liquidity construct of Liu (2006). A plausible explanation may be that the unidimensional character of the proportion of zero returns implies it captures "bad" events as much as "good" events in terms of noise traders reacting to news revelations (disclosures) relating to internal company affairs. Thus, sell orders from adverse informational events generate as many price movements as buy orders from more positive, value-enhancing, events. In this way the Liu liquidity metric offers a more comprehensive measure of liquidity that is more representative of true transactions costs of a given firm's stock.

There are some notable differences between the OECD overall and US only universes in panels 3 and 4. These are price and market capitalization - where both are much higher in lowest governance decile (D1) than the highest decile (D10) in OECD overall universe (panel 3), while the opposite is true in the US only universe (panel 4). This may be explained by there being a greater number of equity markets in the OECD universe than in the single-jurisdiction US market. Therefore, there is greater variation in levels of minority investor protection leading to a propensity for more concentrated cash flow ownership and block shareholders in weakest governance deciles. Block shareholders are less interested in enacting costly democratic governance reforms that would both dilute their cash flow holding, voting control and influence over internal affairs and strategic orientation of the firm. However, in weaker investor protection environments, there is less institutional protection afforded to minority outside shareholders, implying significant value attached to block shareholders whose long term incentives within the firm enhance value. This is reflected in a trend of increasing stock price from highest governance deciles (D10) to lowest governance deciles (D1). The opposite would be expected to be true in the single jurisdiction of US where generally high institutional quality afford optimal protections for minority investors. Here stock prices, indicating elevated value, are attached to firms adhering to democratic outward governance structure that reduces bonding costs and exacerbates 
transparency for minority outsiders. This would support the theory with respect to low investor protection, that is, where there are weaker minority shareholder rights the stock market plays a less important role in the economy compared to high investor protection environments (La Porta et al, 1997, 1998). The lower price associated with lower investor protection deciles supports the view that poorer investor protection and the greater likelihood of insider or controlling shareholder expropriation of minorities, leads to lower prices (La Porta et al, 1999, 2000).

\section{Results}

\subsection{Time-invariant empirical results}

Our two-factor CAPM augmented with the new investor protection factor to account for institutional differences across international markets and the comparisons with existing models are in Appendix D, Table 1D. These are the CAPM, the Fama and French three factor model (FF3F), the Carhart four factor model, that is, the FF3F model augmented with an additional momentum factor (Carhart 4F), the Liu liquidity two factor model (Liquidity 2F) and the Investor Protection two factor model (IP2F). All models are estimated using time series OLS, following Black, Jensen and Scholes (1972), Fama and French (1993), Pastor and Stambaugh (2003) and Liu (2006). The expectation is that the Jensen alpha should not be statistically different from zero, given the relationship between an individual portfolio's expected returns and the market (Markowitz 1959) ${ }^{\mathbf{8}}$.

The estimation results of the augmented CAPM models on the equally-weighted ten investor protection decile portfolios and the equally-weighted and value-weighted FMP using D1 - D10 are reported in Table 6. These are given for all three universes: OECD overall, OECD excluding US and US in panels 1 to 3 respectively. A general finding for all ten investor protection deciles (D1 to D10) in all models (the CAPM, FF3F, Carhart 4F, Liquidity 2F, Investor Protection 2F and the new Governance $2 \mathrm{~F}$ ) is that the adjusted- $\mathrm{R}^{2}$ increases by between $1 \%$ to $5 \%$ in the Governance $2 \mathrm{~F}$ model (see panel F) compared to all other models in each of the universes. However, the strongest support for the new Governance $2 \mathrm{~F}$ model is the reduced statistical significance of the alpha terms for all decile portfolios relative to the other models in the three market universes. A final characteristic of the Governance 2F models is the sign on the governance FMP coefficient. Common to the three universes is the positive, large and statistically significant coefficient in the weakest investor protection deciles (D1) that becomes negative in the strongest (D10). This sign reversal is expected and reflects the premium associated with stocks in weak minority shareholder protection environments that is absent

\footnotetext{
${ }^{8}$ One limitation to the use of standard OLS time series has been noted in the recent literature on CAPM beta instability that results from structural breaks in the underlying data generating process (see Bollerslev and Zhang, 2003; Braun et al, 1995; Lettau and Ledvigson, 2001). Thus, we also examine time-varying parameter CAPM models explained in the next section.
} 
for stocks in strong investor protection environments. So, the negative coefficients infer a progressive trend towards a discount on a "dispersed ownership" or "democratic" governance model within high institutional quality contexts (i.e. that of Berle and Means (1932) and with optimal protection of the institutional environment that supports a third party contracting and external governance model. In such high institutional quality contexts, third party contracting is supported and minority shareholder rights are better enforced and protected. Therefore, uncertainties about the true intentions of block shareholders (e.g. from their elevated potential for expropriation) are mitigated. The presence of a premium in lower governance deciles represents both weakness in the external contracting environment and higher uncertainties with respect to block holder intentions regarding appropriation, which occur within governance structures dominated by large block entities. The transition in the direction for the coefficient on governance FMP is identical to that for the investor protection FMP (based on cross product of free float and institutional quality) which is also reported in Hearn et al (2017). This further substantiates our argument regarding the persistence of a pricing anomaly that mirrors an underlying state variable related to revealed preferences of controlling shareholders towards the expropriation of minorities.

A notable feature of our results between the investor protection models in panel $\mathrm{E}$ and governance models in panel $\mathrm{F}$ is that the trend of the direction (sign) on the governance and investor protection betas ranging from low to high governance decile is the same in all OECD universes bar the US only case. As such, there is a premium on poorly governed firms (e.g. D1) transitioning to a discount on well governed firms (e.g. D10). Only in the US case is there an investor protection premium across all governance quality ranked deciles. This further substantiates our argument regarding governance being a reliable proxy for an underlying state variable based on revealed preferences towards expropriation from minorities.

The last two columns of Table 6 show the results of the estimation of the various pricing models to the zero-cost portfolios formed from the returns difference between low investor protection (D1) and high investor protection (D10) portfolios. This is the returns generated from a strategy of buying stocks in low investor protection firms and selling those where shareholder rights are protected. Estimation results for the CAPM, FF3F, Carhart 4F, Liquidity 2F and Investor Protection 2F models show the regression alpha can be viewed as the abnormal return that cannot be attributed to any of the included FMPs. Gompers et al (2003) describe these as "...the return in excess of what could have been achieved by passive investments in any of the factors" (p. 122).

Following Gompers, we include both equal and value-weighted returns difference portfolios (see the final two columns). For the OECD overall universe (panel 1) we find a persistent abnormal 
return in terms of a statistically significant alpha $(p \leq 0.05)$ in all models applied to the value-weighted difference portfolio. This abnormal return ranges from -0.4 basis points per month in the CAPM to -0.7 basis points per month in the Liquidity $2 \mathrm{~F}$ model. However, evidence to support an abnormal return attributable to investor protection is not so clear in the equal-weighted portfolio. Here, the alpha in the Carhart 4F model, Liquidity 2F model and Investor Protection 2F model are statistically significant $(p \leq 0.05)$, while in the CAPM and the FF3F model it is statistically insignificant. This suggests that for these models, the investment styles are sufficient to capture differences in the cross section. The evidence is more consistent for the OECD excluding US universe in panel 2 where all regression alphas for all models applied to both equal-weighted and value-weighted difference portfolios are statistically significant $(p \leq 0.05)$. Finally, the evidence is mixed for the US only universe (panel 3) where all alphas from application of all models to equally-weighted difference portfolios are statistically significant $(p \leq 0.05)$ while only those for CAPM, FF3F, Carhart $4 \mathrm{~F}$ are statistically significant $(p \leq 0.05)$ for value-weighted difference portfolio. However, it should be noted that the variance of value-weighted portfolios is largely reflective of a handful of large stocks that overwhelmingly dominate the portfolio simply because of their relative size. In contrast, equalweighted portfolios variances are more reflective of the broader cross section of stocks constituent to the portfolio.

Finally, the strongest support for the governance FMP and the two-factor model is found from its application to explain ten investor protection sorted deciles in panel $G$ for each of the three universes. Here, Gov2F regression alphas generally lack statistical significance across all ten investor protection deciles, while the coefficient on the governance FMP is generally statistically significant. Furthermore, adjusted- $\mathrm{R}^{2}$ are high across all models and comparable to those of the Gov2F models applied to governance deciles (panel F).

In summary the evidence so far points to the maintenance of proposition 1 that a premium exists for governance, where this is defined as the product of state institutional quality and individual firm's governance. However, the evidence from the statistical significance of alphas and the explanatory power (adjusted- $\mathrm{R}^{2}$ ) of models is more varied across the different universes. This implies weaker support for proposition 2 where other FMPs such as the size (SMB), book-to-market (HML), Investor Protection 2F (IP) and particularly Liquidity $2 \mathrm{~F}$ (LIQ) are equally as good as Governance $2 \mathrm{~F}$ (GOV) in explaining the cross section of stock returns. Momentum is noticeably extremely poor in explaining returns in any multi-country setting and is only of relevance in the single-country context of US. Notably LIQ and IP are often equally as robust in explaining the cross section of stock returns as our GOV measure. However, this is likely to be due to a large overlap in the nature of transactions 
costs captured by all three measures - where these additionally take into consideration market microstructural characteristics in the case of liquidity. However, an overlooked part of studies to date is that of consideration of ownership types and the specific type of blockholder rather than simply a generic designation of block ownership that typically assumes cash flow ownership concentration. Consideration of ownership types is reported in Appendix D, Table 1D, together with some observations. One immediate observation is the dominance of institutional shareholders in US market through investment companies and pension funds elevated holdings. This is in marked contrast to the rest of OECD where cross-shareholder networks prevail alongside family/employee ownership. Interestingly, despite these differences, our results regarding a governance premium hold.

\section{Table 6}

\subsection{Time varying parameter empirical evidence}

The final set of asset pricing tests is for the Kalman filter time-varying parameter coefficient models. We apply the Kalman filter estimation, which relies on the notion of state space to estimate the conditional constant term and market beta of the investor protection augmented CAPM, as well as of the comparison models ${ }^{9}$. The Kalman filter estimation allows the relaxation of assumptions on data generating processes and a stochastic time trend accounts for structural breaks. This is preferred to formal switching-regression models as it is not necessary to define the exact point of the switch. This is particularly important in the present study as although the timing of changes is known, the exact date of implementation is not, particularly with respect to changes in formal institutions and regulatory environments. A further benefit of Kalman filter estimation is that it is less demanding of the data compared with Markov-switching models that are generally incompatible with short sample periods (see Grout and Zalewska, 2006). The process consists of an observation equation and a transition or state equation, which in combination express the structure and dynamics of a time varying system. A state space model is specified where an observation at time $t$ is a linear combination of a set of state variables that compose the state vector. The time-varying parameter coefficient models of the Governance 2F augmented CAPM and our comparison models are outlined in Appendix D, Table 1D.

The results are reported in Table 7. The four test assets are the ten size and book-to-market decile portfolios, the ten decile investor protection sorted portfolios and a collection of equallyweighted individual market portfolios that form each of the four universes. These provide a diverse range of test assets to assess the efficiency of our models.

\footnotetext{
${ }^{9}$ Applications of this method include Grout and Zalewska (2006), who examine the effects of regulation on UK and US stocks, and Brooks et al. (1998) who investigate Australian industry portfolios. This approach is appropriate to the measurement of time evolving risk premiums for market and investor protection factors (Grout and Zaleswska, (2006)
} 
In general, maximum likelihood statistical convergence is achieved on average for $80 \%$ of the six models applied to the four sets of test assets in each universe. Model selection is based on two sets of statistics: information criteria (Schwarz-Bayesian Criterion, SBC; Hannan-Quinn Criterion, HQC; and Akaike Information Criterion, AIC), and the time series profile of the alpha across models.

Panel 1 (OECD overall universe) shows that the Governance 2F model has the lowest values for decile size, book-to-market and governance test assets and outperforms all other models in terms of the three information criteria. However, the Investor Protection $2 \mathrm{~F}$ model is preferred in decile investor protection test assets. In the OECD excluding US markets universe (panel 2) asset pricing tests using decile size and governance test assets favour the Governance 2F model, while both decile book-tomarket and investor protection test assets favour the Carhart 4F model. Finally, in the US only markets universe (panel 3) the Governance model is favoured over decile size, investor protection and governance test assets while the Carhart 4F model is only superior in the book-to-market portfolios context.

In summary, these time-varying parameter results provide support for the efficiency of the Governance 2F model across OECD universe and subordinate OECD excluding US and US only universes as well as a range of test assets. This is supportive of both propositions 1 and 2 . It is noted that in the investor protection decile test assets the alpha is smallest and the share of standard errors that are below zero are highest for the Governance $2 \mathrm{~F}$ model. This provides some evidence of the benefits of the governance FMP in explaining the cross section of stock returns and its persistence as a viable factor proxying an underlying state variable linked to preferences toward expropriation in explaining pricing anomalies. It equally questions the arguments of Bebchuck et al (2013) that differences in governance are "learned" by market participants and then arbitraged away as these are ultimately incorporated into stock prices.

\section{Table 7}

\section{Robustness Tests.}

We test the robustness of our results by considering another proxy for institutional quality, namely the Legal Structure and Security of Property Rights Index of Gwartney and Lawson (2007) - thereafter $\mathrm{GL}^{10}$. This index captures the dimensions of institutional quality that relate specifically to protection and enforcement of property rights associated with economic and financial stakeholders and particularly those associated with minority outside investors. We re-estimate all our main models using

${ }^{10} \mathrm{We}$ are grateful to the anonymous referee for suggesting this alternative proxy for institutional quality. 
the GL index. ${ }^{11}$ The results are not reported here but are available online. ${ }^{12}$ The evidence provides even stronger support for our main analysis that used the broader Kaufman et al (2009) World Governance index.

We first calculate the FMP summary statistics for the aggregate World market universe, and provide details of the nationality of stocks sorted into each of the decile IP portfolios over time. ${ }^{13}$ The distribution of stocks is on the whole similar to our main results in Table 5, providing reassurance for the robustness of our stock sorting process and models, with one difference. There is one slight difference with this being a more even distribution of Scandinavian stocks across all ten governance decile portfolios when using the GL index. This contrasts with a very visible increasing trend of Scandinavian stocks from lowest governance decile D1 to highest decile D10 apparent with using the Kaufman World Governance index.

We then present the estimation results from the time invariant CAPM, FF3F, Carhart $4 \mathrm{~F}$, Liquidity $2 \mathrm{~F}$, Investor Protection $2 \mathrm{~F}$ and our Governance $2 \mathrm{~F}$ models, for both universes, namely OECD overall and OECD excluding US. ${ }^{14}$ These universes are those susceptible to institutional change and differences between national institutional frameworks that is picked up in our governance measure. The US only universe is the same as in our main results as being a single country the governance measure in effect becomes a metric capturing solely the differences in governance between firms. The results provide substantial support for those obtained in our main analysis when using the Kaufman World Governance index. In particular, there is consistent support in both universes, and confirms the superiority of our new Gov2F model over comparable FF3F, Carhart 4F, Liquidity $2 \mathrm{~F}$ and IP2F configurations. This is evident in terms of higher adjusted $\mathrm{R}^{2}$ and low regression Jensen alphas in both in terms absolute size and negligible statistical significance. However, the strongest support for our new IP measure is in the farthest two right hand columns that outline the results from testing all other factor models that explain the variance of equal and value weighted IP portfolios. In all cases the regression Jensen alphas are large and statistically significant.

Results from the application of time varying parameter models also provide further significant support for our Gov2F model. ${ }^{15}$ Here the Gov2F model outperforms all other time-varying parameter models (based on CAPM, FF3F, Carhart 4F, Liquidity 2F and IP2F) in terms of informational criteria (SBC, AIC, HQC). This is also substantiated by the high proportions of models that attain maximum

\footnotetext{
${ }^{11}$ Index values can be obtained from the authors' website: http://www.freetheworld.com/

${ }^{12}$ The tables can be accessed in Appendix E of the SSRN version of the paper.

${ }^{13}$ see Appendix E, Table $1 \mathrm{E}$ on the online version.

${ }^{14}$ See Appendix E, Table $2 \mathrm{E}$ on the online version.

${ }^{15}$ See Appendix E, Table 3E on the online version.
} 
likelihood convergence, for example, over $70 \%$ for our new Gov2F model. These time varying results are notably better than those reported in Table 7 of the main analysis.

\section{Conclusions}

The level of investor protections afforded by firms to minority owners is reflective of the revealed preferences towards expropriation by controlling insider groups or block holders. These are the focus of the decision to appropriate cash flows rather than pay dividends - where these infringements on property rights are typically hard to measure and evaluate. The outward governance structure of the firm acts to reduce bonding costs and enhance transparency for minorities and thus is a suitable proxy for these underlying appropriation tendencies in terms of whether insiders prefer to adopt costly governance provisions of benefit from an aggregate reduction in the cost of funds that facilitates longer term productivity and profitability of the firm. We argue that contrary to adaptive efficient market theory, investors and market participants do not "learn" the differences between strongly and weakly governed firms and ultimately incorporate these into stock prices. Rather, we argue that outward governance structure is itself a dynamic changing notion and is reflective of underlying changes regarding the revealed preferences towards expropriation by controlling insiders. In this way differences in returns for firms across the cross section of stock returns are reflective of a pervasive underlying state variable that is responsible for persistent pricing anomalies.

We propose a new governance measure of investor protection that is the product of national institutional quality and the governance rating of firms. Firms governance provisions are assessed on the basis of whether they are "democratic" and enhancing minority shareholder protections, or "dictatorship" and engendering insiders control. Extensive tests of variants of the augmented-CAPM, including time-varying parameter Kalman filter methods, show that a two factor CAPM augmented with a factor mimicking portfolio based on our new investor protection metric yields the highest explanatory power for a cross section of stock returns. Our evidence reveals consistent support for the new governance valuation factor and an governance premium attributable to minorities participating in weakly (dictatorship-orientated) governed firms as opposed to a discount for participating in their strongly (democracy-orientated) counterparts. These findings are consistent across single-country (US only) and multi-country (OECD) samples where these groups of markets are characterised by considerable variation in the types of ownership prevalent.

In general, our results indicate variations in abnormal returns on portfolios that reflect returns differences between democratic (strong) and dictatorship (weak) governance sorted deciles not explained by existing augmented CAPMs. These abnormal returns range from 0.4 basis pints per 
month (4.91\% per annum) for equal weighted to over -1.0 basis points per month (-11.36\% per annum) for value weighted portfolios. This confirms the importance of differences in governance and that minority investors should seek a premium to compensate for potential welfare losses and a means of hedging these losses within a conventional asset pricing framework. 


\section{References}

Albuquerue, R., \& Wang, N. (2008). Agency conflicts, investment, and asset pricing. The Journal of Finance, LXIII(1), 1-40

Bebchuck, L., Cohen, A., \& Ferrell, A. (2009). What matters in corporate governance. Review of Financial Studies, 22, 783-827

Bebchuck, L., Cohen, A., \& Wang, C. C. Y. (2013). Learning and the disappearing association between governance and returns. Journal of Financial Economics, 108, 322-348

Berle, A. \& Means, G. (1932) The Modern Corporation and Private Property. New York, Macmillan

Bewley, T. F. (2002). Knightian decision theory. Part I. Decisions in Economics and Finance, 25, 79110

Black, F., Jensen, M. C., Scholes, M., 1972. The capital asset pricing model: Some empirical tests. In M. C. Jensen (ed.), Studies in the Theory of Capital Markets. New York, NY: Praeger

Bollerslev T. \& Zhang, B. (2003) Measuring and Modeling Systematic Risk in Factor Pricing Models using High-Frequency Data. Journal of Empirical Finance, 10, 533-558

Braun P., Nelson, D. \& Sunier, A. (1995) Good News, Bad News, Volatility, and Betas. Journal of Finance, 50, 1575-1603

Brooks, R. D., Faff, R. W. \& McKenzie, M. D. (1998) Time-varying beta risk of Australian industry portfolios: A comparison of modelling techniques. Australian Journal of Management, 23, 122

Carhart, M. M., 1997. On persistence in mutual fund performance. Journal of Finance, 52, 57-82

Charitou, A., Louca, C., \& Panayides, S. (2007). Cross-Listing, Bonding Hypothesis and Corporate Governance. Journal of Business Finance \& Accounting, 34(7), 1281-1306

Chen, K. C. W., Chen, Z., \& Wei, K. C. J. (2009). Legal protection of investors, corporate governance, and the cost of equity capital. Journal of Corporate Finance, 15, 273-289

Coffee, J. (1999). The future as history: The prospects for global convergence in governance and its implications. Northwestern University Law Review, 93, 641-708

Coffee, J. (2002). Racing towards the top? The impact of cross-listing and stock market competition on international corporate governance. Columbia Law Review, 102, 1757-831

Daniel, K., \& Titman, S. (1999). Market efficiency in an irrational world. Financial Analysts Journal, $55,28-40$

Djankov, S., La Porta, R., Lopez-de-Silanes, F., and Shleifer, A. (2008). The law and economics of self-dealing, Journal of Financial Economics. 88, 430-465 
Doidge, C., Karolyi, A., \& Stulz, R. (2007) Why do countries matter so much for corporate governance? Journal of Financial Economics, 86, 1-39

Errunza, V., \& Losq, E. (1985). International asset pricing under mild segmentation: Theory and test. The Journal of Finance, 40(1), 105-124

Fama, E. (1970). Efficient capital markets: a review of theory and empirical work. Journal of Finance, $25,383-417$

Fama, E. F., (1980). Agency problems and the theory of the firm. Journal of Political Economy, 88, 288-306

Fama, E., \& French, K. (1993). Common risk factors in the returns on stocks and bonds. Journal of Financial Economics, 33, 3-56

Giannetti, M., \& Koskinen, Y. (2010). Investor protection, equity returns, and financial globalization. Journal of Financial and Quantitative Analysis, 45(1), 135-168

Gompers, P., Ishii, J., \& Metrick, A. (2003). Corporate governance and equity prices. The Quarterly Journal of Economics, 118(1), 107-155

Goyenko, R. Y., Holden, C. W., \& Trzcinka, C. A. (2009). Do liquidity measures measure liquidity? Journal of Financial Economics, 92, 153-181

Grout, P. A. \& Zalewska, A. (2006) The impact of regulation on market risk. Journal of Financial Economics, 80, 149-184

Gwartney, J., \& Lawson, R. (2007). Economic Freedom of the World: 2007 Annual Report. The Fraser Institute, Vancouver. Data retrieved from www.freetheworld.com

Hearn, B. (2014). The political institutional and firm governance determinants of liquidity: Evidence from North Africa and the Arab Spring. Journal of International Financial Markets, Institutions \& Money, 31, 127-158

Hearn, B., Phylaktis, K., \& Piesse, J. (2017). Expropriation risk by block holders, institutional quality and expected stock returns. Journal of Corporate Finance, 45, 122-149

Heinkel, R., Krauss, A., \& Zechner, J. (2001). The effect of green investment on corporate behaviour. Journal of Financial and Quantitative Analysis, 36(4), 431-449

Hou, K., Karolyi, G. A., \& Kho, B-C. (2011). What factors drive global stock returns? Review of Financial Studies, 24(8), 2527-2574

Ince, O., \& Porter, R. B. (2003). Individual equity return data from Thomson Datastream: Handle with care! Journal of Financial Research, 29, 463-479

Jegadeesh, N., \& Titman, S. (1993). Returns to buying winners and selling losers: Implications for stock market efficiency. The Journal of Finance, 48(1), 65-91 
Jegadeesh, N., \& Titman, S. (2001). Profitability of momentum strategies: An evaluation of alternative explanations. The Journal of Finance, 56(2), 699-720

Jensen, M. C., \& Meckling, W. (1976). Theory of the firm: managerial behavior, agency costs, and ownership structure. Journal of Financial Economics, 3, 305-360

Kaufman, D., Kraay, A., \& Mastruzzi, M. (2009). Governance Matters VIII: Governance Indicators for 1996-2008. World Bank Policy Research Unit June 2009

Klapper, L. F., \& Love, I. (2004). Corporate governance, investor protection, and performance in emerging markets. Journal of Corporate Finance, 10, 703-728

La Porta, R., Lopez-de-Silanes, F., Schliefer, A., \& Vishny, R. (1997). Legal Determinants of External Finance. The Journal of Finance, 52, 1131-1150

La Porta, R., Lopez-de-Silanes, F., Schliefer, A., \& Vishny, R. (1998). Law and Finance. Journal of Political Economy, 106(6), 1113-1155

La Porta, R., Lopez-de-Silanes, F., \& Shleifer, A. (1999). Corporate ownership around the World. The Journal of Finance, 54, 471-518

La Porta, R., Lopez-de-Silanes, F., Schliefer, A., \& Vishny, R. (2000). Investor protection and corporate governance. Journal of Financial Economics, 58, 3-27

La Porta, R., Lopez-de-Silanes, F., Schliefer, A., \& Vishny, R. (2002). Investor protection and corporate valuation. The Journal of Finance, 57(3), 1147-1170

Lesmond, D. A. (2005). Liquidity of emerging markets. Journal of Financial Economics, 77, 411-52

Lettau, M. \& Ledvigson, S. (2001) Consumption, Aggregate Wealth, and Expected Stock Returns. The Journal of Finance, LVI (3), 815 - 849

Liu, W., 2006. A Liquidity-augmented capital asset pricing model. Journal of Financial Economics, $82,631-671$

Markowitz, H. (1959). Portfolio Selection: Efficient Diversification of Investments. John Wiley and Sons, New York; Chapman and Hall, London, 1959

North, D. C. (1991). Institutions. Journal of Economic Perspectives, 5(1), 97-112

North, D. (1994) Economic performance through time. The American Economic Review, 84 (3), 35968

O’Hara, M. (2003): Presidential address: liquidity and price discovery. Journal of Finance, 58, 13351354

Pastor, L. \& Stambaugh, R. (2003) Liquidity risk and expected stock returns. Journal of Political Economy, 111, 642-685

Schleifer, A., \& Vishny, R. (1997). The limits of arbitrage. Journal of Finance, 52, 35-55 
Spamann, H. (2010). The “Antidirector Rights Index” revisited, Review of Financial Studies, 23, 467486

Thomson Reuters ESG Scores (2017). Thomson Reuters ESG Scores.

http://financial.thomsonreuters.com/esg Accessed 14 September 2017

Williamson O. E. (2000). The new institutional economics: Taking stock, looking ahead. Journal of Economic Literature, 38(3), 595-613

Williamson, O. E. (2002). The theory of the firm as governance structure: From choice to contract. Journal of Economic Perspectives, 16(3), 171-195 


\section{Table 1. Individual elements of firm-level governance}

This table outlines the governance elements we have included as an integral part of the firm-level governance structure. Each element is sourced from Thomson Reuters ASSET4-ESG database and has been classified in terms of "democracy" or "dictatorship" in relation to the degree of power it gives external minority shareholders in comparison with incumbent insiders. This classification follows Gompers, Ishii \& Metrick (2003). Each element is defined and has been included due to its simple binary coding of "Y" or "N" which can be easily codified into binary 1/0 facilitating the formation of a governance index.

\begin{tabular}{|c|c|c|}
\hline Governance element & Type & Definition \\
\hline \multicolumn{3}{|l|}{ Minority rights } \\
\hline Board diversity policy & Democracy & $\begin{array}{l}\text { Does the company have a policy regarding the diversity of its } \\
\text { board? }\end{array}$ \\
\hline Adequate experience of board policy & Democracy & $\begin{array}{l}\text { Does the company have a policy regarding the adequate } \\
\text { experience on its board? }\end{array}$ \\
\hline Board independence policy & Democracy & $\begin{array}{l}\text { Does the company have a policy regarding the independence } \\
\text { of its board? }\end{array}$ \\
\hline Board size policy & Democracy & $\begin{array}{l}\text { Does the company have a policy regarding the size of its } \\
\text { board? }\end{array}$ \\
\hline CEO board member & Democracy & The CEO is a board member. \\
\hline Chairman is ex-CEO & Dictatorship & $\begin{array}{l}\text { Has the chairman previously held the CEO position in the } \\
\text { company? }\end{array}$ \\
\hline Nomination committee & Democracy & Does the company have a nomination committee? \\
\hline Succession plan for executives & Democracy & $\begin{array}{l}\text { Does the company have a succession plan for executive } \\
\text { management in the event of unforeseen circumstances? }\end{array}$ \\
\hline Corporate governance committee & Democracy & Does the company have a corporate governance committee? \\
\hline External consultants & Democracy & $\begin{array}{l}\text { Does the board or board committees have the authority to } \\
\text { hire external advisers or consultants without management's } \\
\text { approval? }\end{array}$ \\
\hline Golden parachute & Dictatorship & $\begin{array}{l}\text { Does the company have a golden parachute or other } \\
\text { restrictive clauses related to changes of control } \\
\text { (compensation plan for accelerated pay-out)? }\end{array}$ \\
\hline Limitation of director liability & Dictatorship & Does the company have a limitation of director liability? \\
\hline Limitations on removal of directors & Dictatorship & $\begin{array}{l}\text { Are there limitations on the shareholders' right to remove } \\
\text { board members (i.e., only for cause, supermajority vote } \\
\text { required, etc.)? }\end{array}$ \\
\hline $\begin{array}{l}\text { Limited shareholder rights to call } \\
\text { meetings }\end{array}$ & Dictatorship & $\begin{array}{l}\text { Has the company limited the rights of shareholders to call } \\
\text { special meetings? }\end{array}$ \\
\hline $\begin{array}{l}\text { Majority requirements for election of } \\
\text { directors }\end{array}$ & Dictatorship & $\begin{array}{l}\text { Are the company's board members elected with a majority } \\
\text { vote? }\end{array}$ \\
\hline Poison pill & Dictatorship & $\begin{array}{l}\text { Does the company have a poison pill (shareholder rights plan, } \\
\text { macaroni defence, etc.)? }\end{array}$ \\
\hline
\end{tabular}

\section{Voting}

Advance notice for shareholder proposals

Confidential voting policy

Different share classes different rights

Elimination of cumulative voting rights

Expanded constituency provision

Fair price provision

Democracy Does the company have deadlines relating to shareholder proposals?

Democracy Does the company have a confidential voting policy (i.e., management cannot view the results of shareholder votes)?

Dictatorship Does the company have different class stocks with different voting rights?

Dictatorship Has the company reduced or eliminated cumulative voting in regard to the election of board members?

Democracy Does the company have expanded-constituency provisions in place?

Democracy Is the company subject to fair price provision, either under applicable law or as stated in the company documents (charter or bylaws)?

Min. number of shares to vote

Dictatorship Has the company set requirements for a minimum number of shares to vote?

Voting cap

Dictatorship Does the company have shares with a voting cap (ceilings) clause, ownership ceilings or control share acquisition provision? 


\begin{tabular}{|c|c|c|}
\hline $\begin{array}{l}\text { Significant company transactions } \\
\text { (M\&A) shareholder's approval }\end{array}$ & Dictatorship & $\begin{array}{l}\text { Limitations to the shareholders right to approve significant } \\
\text { company transitions such as M\&As (no rights to vote or } \\
\text { supermajority required)? }\end{array}$ \\
\hline Supermajority vote requirements & Dictatorship & $\begin{array}{l}\text { Does the company have a supermajority vote requirement or } \\
\text { qualified majority (for amendments of charters and bylaws or } \\
\text { lock-in provisions)? }\end{array}$ \\
\hline Written consent requirements & Democracy & $\begin{array}{l}\text { Does the company permit actions to be taken without } \\
\text { meeting by written consent? }\end{array}$ \\
\hline Integrated strategy in MD\&A & Democracy & $\begin{array}{l}\text { Does the company explicitly integrate financial and extra- } \\
\text { financial factors in its management discussion and analysis } \\
\text { (MD\&A) section in the annual report? }\end{array}$ \\
\hline Equal voting right policy & Democracy & $\begin{array}{l}\text { Does the company have a policy to apply the one-share, one- } \\
\text { vote principle? }\end{array}$ \\
\hline Shareholder engagement policy & Democracy & $\begin{array}{l}\text { Does the company have a policy to facilitate shareholder } \\
\text { engagement, resolutions or proposals? }\end{array}$ \\
\hline Pre-emptive rights & Dictatorship & $\begin{array}{l}\text { Does the company grant pre-emptive rights to existing } \\
\text { shareholders? }\end{array}$ \\
\hline Public availability corporate statutes & Democracy & $\begin{array}{l}\text { Are the company's articles of association, statutes or bylaws } \\
\text { publicly available? }\end{array}$ \\
\hline \multicolumn{3}{|l|}{ Delay } \\
\hline Classified board structure & Dictatorship & Does the company have a classified board structure? \\
\hline Staggered board structure & Dictatorship & Does the company have a staggered board structure? \\
\hline Company cross shareholding & Dictatorship & $\begin{array}{l}\text { Does the company have significant cross shareholding that } \\
\text { can prevent takeovers? }\end{array}$ \\
\hline Golden share & Dictatorship & $\begin{array}{l}\text { Does the biggest owner (by voting power) hold the veto } \\
\text { power or own golden shares? }\end{array}$ \\
\hline Blank check & Dictatorship & $\begin{array}{l}\text { Does the company have unlimited authorized capital or a } \\
\text { blank check? }\end{array}$ \\
\hline State owned enterprise & Dictatorship & Is the company a State Owned Enterprise (SOE)? \\
\hline \multicolumn{3}{|l|}{ Director Incentives } \\
\hline $\begin{array}{l}\text { Shareholder's approval of stock } \\
\text { based compensation Plan }\end{array}$ & Democracy & $\begin{array}{l}\text { Does the company require that shareholder approval is } \\
\text { obtained prior to the adoption of any stock based } \\
\text { compensation plans? }\end{array}$ \\
\hline $\begin{array}{l}\text { CEO compensation link to } \\
\text { shareholder return }\end{array}$ & Democracy & Is the CEO's compensation linked to total shareholder return? \\
\hline Compensation committee & Democracy & Does the company have a compensation committee? \\
\hline Compensation improvement tools & Democracy & $\begin{array}{l}\text { Does the company have the necessary internal improvement } \\
\text { and information tools for the board members to develop } \\
\text { appropriate compensation/remuneration to attract and retain } \\
\text { key executives? }\end{array}$ \\
\hline $\begin{array}{l}\text { Executive retention compensation } \\
\text { policy }\end{array}$ & Democracy & $\begin{array}{l}\text { Does the company have a compensation policy to attract and } \\
\text { retain executives? }\end{array}$ \\
\hline $\begin{array}{l}\text { Performance oriented compensation } \\
\text { policy }\end{array}$ & Democracy & $\begin{array}{l}\text { Does the company have a performance oriented } \\
\text { compensation policy? }\end{array}$ \\
\hline Shareholders vote on executive pay & Democracy & $\begin{array}{l}\text { Do the company's shareholders have the right to vote on } \\
\text { executive compensation? }\end{array}$ \\
\hline
\end{tabular}




\section{Table 2 Summary of governance elements}

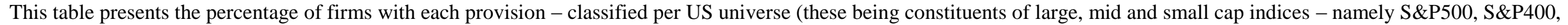

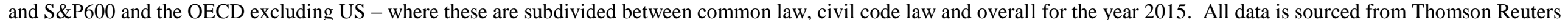
ASSET4-ESG database. It should be noted that this is the proportion of firms that report governance in ASSET4 database that then have implemented any of the governance provisions - be these dictatorship or democracy orientated elements. Cross shareholding element is not reported in any US firms for year 2015.

\begin{tabular}{|c|c|c|c|c|c|c|c|}
\hline \multirow[t]{3}{*}{ Governance element } & \multirow[t]{3}{*}{ Type } & \multicolumn{6}{|c|}{ Percentage (\%) of firms with governance provisions in: } \\
\hline & & \multicolumn{3}{|c|}{ US } & \multicolumn{3}{|l|}{ OECD excl. US } \\
\hline & & S\&P500 & S\&P400 & S\&P600 & Civil Code law & Common law & Overall \\
\hline \multicolumn{8}{|l|}{ Minority rights } \\
\hline Board diversity policy & Democracy & 71.30 & 63.54 & 69.96 & 25.73 & 77.87 & 50.00 \\
\hline Adequate experience of board policy & Democracy & 99.78 & 99.46 & 97.63 & 43.44 & 95.28 & 67.57 \\
\hline Board independence policy & Democracy & 98.43 & 93.83 & 90.91 & 39.43 & 64.94 & 51.31 \\
\hline Board size policy & Democracy & 95.07 & 93.30 & 86.96 & 71.04 & 80.79 & 75.58 \\
\hline CEO board member & Democracy & 98.43 & 95.44 & 97.63 & 41.78 & 84.49 & 61.66 \\
\hline Chairman is ex-CEO & Dictatorship & 73.32 & 63.00 & 53.36 & 22.90 & 13.60 & 18.57 \\
\hline Nomination committee & Democracy & 78.03 & 83.11 & 86.17 & 42.07 & 83.03 & 61.14 \\
\hline Succession plan for executives & Democracy & 98.88 & 97.05 & 94.86 & 36.20 & 90.11 & 61.30 \\
\hline Corporate governance committee & Democracy & 97.09 & 95.17 & 92.49 & 12.33 & 35.96 & 23.33 \\
\hline External consultants & Democracy & 99.55 & 99.73 & 99.60 & 44.42 & 94.49 & 67.73 \\
\hline Golden parachute & Dictatorship & 95.96 & 72.92 & 24.90 & 11.25 & 36.52 & 23.01 \\
\hline Limitation of director liability & Dictatorship & 99.55 & 75.34 & 25.30 & 57.14 & 91.80 & 73.27 \\
\hline Limitations on removal of directors & Dictatorship & 45.52 & 43.16 & 13.44 & 6.56 & 8.88 & 7.64 \\
\hline Limited shareholder rights to call meetings & Dictatorship & 98.65 & 74.53 & 24.90 & 27.01 & 22.13 & 24.74 \\
\hline Majority requirements for election of directors & Dictatorship & 84.08 & 66.49 & 55.73 & 52.94 & 87.53 & 69.04 \\
\hline Poison pill & Dictatorship & 5.38 & 9.38 & 9.09 & 0.29 & 2.92 & 1.52 \\
\hline \multicolumn{8}{|l|}{ Voting } \\
\hline Equal voting right policy & Democracy & 93.95 & 94.37 & 92.89 & 56.36 & 96.29 & 74.95 \\
\hline Shareholder engagement policy & Democracy & 97.98 & 95.98 & 95.26 & 45.69 & 81.46 & 62.34 \\
\hline Pre-emptive rights & Dictatorship & 2.69 & 0.80 & 0.79 & 48.14 & 8.99 & 29.92 \\
\hline Public availability corporate statutes & Democracy & 98.65 & 96.51 & 96.44 & 67.22 & 61.12 & 64.38 \\
\hline Advance notice for shareholder proposals & Democracy & 99.33 & 75.07 & 25.30 & 33.27 & 57.30 & 44.46 \\
\hline Confidential voting policy & Democracy & 50.45 & 23.06 & 7.91 & 5.48 & 6.52 & 5.96 \\
\hline Different share classes different rights & Dictatorship & 6.05 & 5.63 & 6.72 & 40.70 & 3.37 & 23.33 \\
\hline
\end{tabular}




\begin{tabular}{|c|c|c|c|c|c|c|c|}
\hline Elimination of cumulative voting rights & Dictatorship & 77.13 & 54.69 & 19.37 & 18.40 & 3.71 & 11.56 \\
\hline Expanded constituency provision & Democracy & 9.19 & 6.70 & 2.37 & 1.96 & 1.46 & 1.73 \\
\hline Fair price provision & Democracy & 19.06 & 16.89 & 3.16 & 0.78 & 0.34 & 0.58 \\
\hline Min. no. shares to vote & Dictatorship & 0.67 & 1.34 & 1.19 & 32.68 & 1.01 & 17.94 \\
\hline Voting cap & Dictatorship & 2.02 & 1.07 & 0.00 & 5.19 & 2.81 & 4.08 \\
\hline $\begin{array}{l}\text { Significant company transactions (M\&A) shareholder's } \\
\text { approval }\end{array}$ & Democracy & 66.37 & 49.60 & 16.21 & 12.82 & 2.02 & 7.79 \\
\hline Supermajority vote requirements & Dictatorship & 51.57 & 45.31 & 14.62 & 41.78 & 58.43 & 49.53 \\
\hline Written consent requirements & Democracy & 46.86 & 40.21 & 13.83 & 1.17 & 3.60 & 2.30 \\
\hline Integrated strategy in MD\&A & Democracy & 8.52 & 3.49 & 3.16 & 11.55 & 35.51 & 22.70 \\
\hline \multicolumn{8}{|l|}{ Delay } \\
\hline Classified board structure & Dictatorship & 0.00 & 0.00 & 0.00 & 0.68 & 0.00 & 0.37 \\
\hline Staggered board structure & Dictatorship & 20.18 & 32.98 & 9.49 & 16.14 & 32.13 & 23.59 \\
\hline Company cross shareholding & Dictatorship & -- -- & -- -- & -- -- & 0.29 & 0.00 & 0.16 \\
\hline Golden share & Dictatorship & 3.14 & 2.68 & 5.14 & 14.68 & 8.09 & 11.61 \\
\hline Blank check & Dictatorship & 94.17 & 69.17 & 25.30 & 2.05 & 26.74 & 13.55 \\
\hline State owned enterprise & Dictatorship & 0.00 & 0.00 & 0.00 & 2.35 & 0.67 & 1.57 \\
\hline \multicolumn{8}{|l|}{ Director Incentives } \\
\hline Shareholder's approval of stock based compensation Plan & Democracy & 95.07 & 96.51 & 95.65 & 24.27 & 63.37 & 42.47 \\
\hline CEO compensation link to shareholder return & Democracy & 78.92 & 62.47 & 43.08 & 12.33 & 64.61 & 36.66 \\
\hline Compensation committee & Democracy & 95.52 & 97.32 & 98.42 & 42.86 & 87.53 & 63.65 \\
\hline Compensation improvement tools & Democracy & 99.10 & 98.39 & 97.23 & 26.71 & 88.65 & 55.54 \\
\hline Executive retention compensation policy & Democracy & 99.55 & 99.20 & 97.63 & 28.28 & 88.09 & 56.12 \\
\hline Performance oriented compensation policy & Democracy & 100.00 & 99.46 & 99.21 & 65.46 & 92.25 & 77.93 \\
\hline Shareholders vote on executive pay & Democracy & 95.07 & 96.51 & 95.65 & 24.27 & 63.37 & 42.47 \\
\hline Number of constituent firms: & & 500 & 400 & 600 & 2,050 & 1,164 & 3,244 \\
\hline Number of firms with governance (in ASSET4): & & 446 & 373 & 253 & 1,022 & 890 & 1,912 \\
\hline
\end{tabular}


Table 3 Summary of governance, institutional quality and investor protection statistics

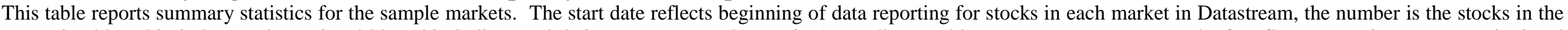

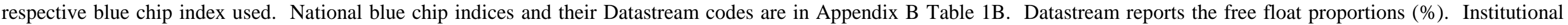

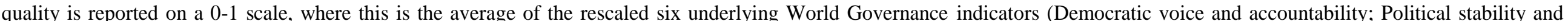

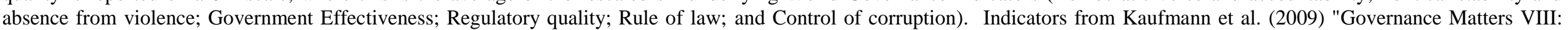

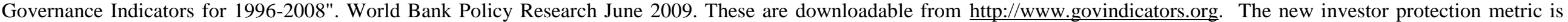

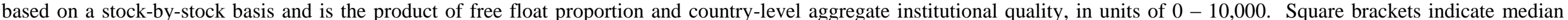
values. Developed and emerging markets are distinguished using the MSCI classification system.

\begin{tabular}{|c|c|c|c|c|c|c|c|c|c|c|}
\hline \multirow[t]{2}{*}{ Country } & \multirow[t]{2}{*}{$\mathbf{N}$} & \multirow[t]{2}{*}{$\mathbf{N}_{\text {ASSET4 }}$} & \multicolumn{2}{|c|}{ Governance metrics } & \multicolumn{3}{|c|}{ Investor protection metrics } & \multicolumn{3}{|c|}{ Descriptive statistics } \\
\hline & & & $\begin{array}{l}\text { Governance } \\
(0-4,500)\end{array}$ & $\begin{array}{l}\text { Firm } \\
\text { governance } \\
(0-45)\end{array}$ & $\begin{array}{l}\text { Investor } \\
\text { Protection } \\
(\mathbf{0}-\mathbf{1 0 , 0 0 0})\end{array}$ & $\begin{array}{l}\text { Free-Float } \\
(\%)\end{array}$ & $\begin{array}{l}\text { Institutional } \\
\text { quality } \\
(0-1)\end{array}$ & $\begin{array}{l}\text { Market cap. } \\
\text { (US\$, b) }\end{array}$ & $\begin{array}{l}\text { Book to } \\
\text { Market value } \\
\text { ratio }\end{array}$ & $\begin{array}{l}\text { Liu Liquidity } \\
\text { metric }\end{array}$ \\
\hline \multicolumn{11}{|l|}{ North America } \\
\hline Canada & 248 & 224 & 2,174 [2197] & 23.69 [24.00] & $7,201[7,927]$ & 78.82 [88.00] & 0.9143 & $4.37[1.27]$ & $0.732[0.565]$ & $17.37[9.65]$ \\
\hline US S\&P 500 & 500 & 446 & $2,242[2,278]$ & $27.05[28.00]$ & $6,370[6,947]$ & $75.81[84.00]$ & 0.8380 & $16.55[0.21]$ & $1.450[0.905]$ & $13.76[8.69]$ \\
\hline US S\&P 400 & 400 & 373 & $2,193[2,221]$ & $26.53[27.00]$ & $6,025[6,425]$ & $72.13[77.07]$ & 0.8380 & $2.81[1.94]$ & $0.504[0.470]$ & $16.69[8.68]$ \\
\hline US S\&P 600 & 600 & 253 & $2,117[2,049]$ & $25.92[25.00]$ & $5,905[6,180]$ & $70.67[75.00]$ & 0.8380 & $0.97[0.61]$ & $0.607[0.541]$ & $18.09[8.69]$ \\
\hline \multicolumn{11}{|c|}{ Europe Developed } \\
\hline Austria & 20 & 13 & $1,658[1,644]$ & 18.49 [18.00] & $4,957[4,902]$ & $54.91[55.00]$ & 0.8962 & $3.19[2.10]$ & $0.841[0.812]$ & $17.26[12.60]$ \\
\hline Belgium & 20 & 19 & $1,867[1,916]$ & $22.12[23.00]$ & $5,324[5,104]$ & $62.78[59.00]$ & 0.8454 & $24.02[7.02]$ & $0.773[0.683]$ & $8.67[5.77]$ \\
\hline France & 60 & 51 & $1,590[1,604]$ & $19.53[20.00]$ & $5,607[5,890]$ & $68.44[72.00]$ & 0.8149 & $22.72[12.41]$ & $0.650[0.531]$ & $7.02[5.77]$ \\
\hline Germany & 100 & 48 & $1,725[1,704]$ & $19.50[19.00]$ & $5,263[6,017]$ & $59.44[68.00]$ & 0.8855 & $10.83[2.65]$ & $1.525[0.529]$ & 21.96 [7.70] \\
\hline Ireland & 47 & 14 & $2,119[2,095]$ & $24.10[23.00]$ & $6,166[6,381]$ & $69.44[71.50]$ & 0.8830 & $187.62[0.47]$ & $1.334[0.573]$ & 57.32 [16.39] \\
\hline Italy & 74 & 1 & $1,073[1,079]$ & $16.17[17.00]$ & $2,921[2,674]$ & $42.96[40.50]$ & 0.6783 & $0.31[0.15]$ & $0.580[0.685]$ & 15.84 [7.72] \\
\hline Luxembourg & 9 & 2 & $1,860[1,976]$ & $19.98[21.00]$ & $4,661[4,858]$ & $49.97[52.00]$ & 0.9348 & 10.77 [1.23] & $1.504[1.304]$ & 54.18 [22.29] \\
\hline Netherlands & 140 & 40 & $2,145[2,167]$ & 23.14 [23.00] & $5,901[6,300]$ & $63.32[66.00]$ & 0.9315 & $112.51[0.67]$ & $0.780[0.582]$ & $26.54[5.77]$ \\
\hline Portugal & 47 & 11 & $1,548[1,583]$ & $19.73[20.00]$ & $2,967[2,689]$ & $37.83[34.55]$ & 0.7860 & $2.64[0.19]$ & $0.934[0.728]$ & $38.50[5.81]$ \\
\hline Spain & 108 & 49 & $1,642[1,705]$ & $21.80[22.00]$ & $4,258[4,011]$ & $55.89[54.61]$ & 0.7629 & $9.17[0.93]$ & $0.601[0.599]$ & $16.59[5.81]$ \\
\hline Switzerland & 100 & 61 & $1,900[1,867]$ & $20.22[20.00]$ & $6,183[6,424]$ & $65.57[68.50]$ & 0.9429 & 8.87 [1.93] & $0.595[0.456]$ & $13.99[9.61]$ \\
\hline UK FTSE 100 & 101 & 98 & $2,206[2,166]$ & $25.34[25.00]$ & $6,526[7,779]$ & $74.05[89.00]$ & 0.8768 & $25.89[9.46]$ & $0.548[0.416]$ & $10.75[7.72]$ \\
\hline UK FTSE 250 & 251 & 234 & $2,014[2,029]$ & $23.12[23.00]$ & $6,008[7,141]$ & $68.01[80.87]$ & 0.8768 & $1.53[1.07]$ & $0.745[0.576]$ & $17.10[7.72]$ \\
\hline \multicolumn{11}{|l|}{ Scandinavia } \\
\hline Denmark & 135 & 34 & $1,875[1,850]$ & 19.69 [19.00] & $5,797[5,838]$ & $60.42[61.00]$ & 0.9556 & $7.73[0.08]$ & $0.931[0.816]$ & $53.79[14.48]$ \\
\hline Finland & 135 & 31 & $1,870[1,888]$ & $19.37[20.00]$ & $5,946[6,201]$ & $61.19[65.50]$ & 0.9683 & $2.22[0.24]$ & $0.714[0.610]$ & $34.75[10.62]$ \\
\hline Iceland & 16 & 0 & --- & --- & $3,459[3,133]$ & $38.18[32.50]$ & 0.9146 & $0.29[0.21]$ & $0.751[0.577]$ & 106.16 [67.58] \\
\hline Norway & 25 & 17 & $1,932[1,995]$ & 20.63 [21.00] & $5,677[5,481]$ & $60.53[58.25]$ & 0.9359 & $8.95[1.98]$ & $0.766[0.649]$ & $16.63[9.65]$ \\
\hline Sweden & 89 & 58 & $1,859[1,874]$ & $19.64[20.00]$ & $6,590[7,070]$ & $69.43[74.54]$ & 0.9452 & $6.96[1.65]$ & $0.645[0.515]$ & $14.36[9.65]$ \\
\hline \multicolumn{11}{|c|}{ Europe Emerging } \\
\hline Czech Republic & 24 & 6 & $1,329[1,289]$ & $17.93[17.50]$ & $2,526[2,240]$ & $34.63[30.00]$ & 0.7338 & $2.28[0.35]$ & $1.286[0.947]$ & 66.97 [9.69] \\
\hline
\end{tabular}




\begin{tabular}{|c|c|c|c|c|c|c|c|c|c|c|}
\hline Estonia & 32 & 0 & --- & ---- & $3,770[3,167]$ & $47.96[40.00]$ & 0.7804 & $0.14[0.05]$ & $0.855[0.856]$ & $116.21[103]$ \\
\hline Greece & 60 & 18 & $1,212[1,224]$ & $18.72[18.50]$ & $3,406[3,016]$ & $51.06[43.17]$ & 0.6568 & $0.54[0.21]$ & $1.332[0.942]$ & 20.52 [11.13] \\
\hline Hungary & 14 & 4 & $1,372[1,428]$ & $19.71[21.00]$ & $3,586[3,618]$ & $49.74[50.00]$ & 0.7148 & $1.43[0.11]$ & $0.919[0.777]$ & $23.99[11.63]$ \\
\hline Latvia & 67 & 0 & -- -- & -- -- & $2,127[1,337]$ & $31.08[20.00]$ & 0.6871 & 44.27 [4.15] & $1.231[1.859]$ & $132.08[110]$ \\
\hline Poland & 20 & 8 & $1,123[1,096]$ & $15.87[15.00]$ & $3,464[3,487]$ & $49.59[49.50]$ & 0.7006 & $4.21[3.15]$ & $0.720[0.644]$ & 18.20 [9.69] \\
\hline Slovakia & 50 & 0 & ---- & ---- & $1,494[1,204]$ & $21.27[18.00]$ & 0.7004 & $0.12[0.06]$ & $2.883[2.428]$ & 178.58 [198] \\
\hline Slovenia & 7 & 0 & -- -- & -- -- & $4,320[4,704]$ & $57.24[63.00]$ & 0.7549 & $0.69[0.47]$ & $1.069[0.823]$ & $19.55[12.55]$ \\
\hline \multicolumn{11}{|l|}{ Australasia } \\
\hline Australia & 300 & 259 & $2,164[2,214]$ & $24.06[25.00]$ & $6,458[6,769]$ & $71.61[75.00]$ & 0.9067 & $3.40[0.67]$ & $0.675[0.556]$ & 29.96 [7.75] \\
\hline New Zealand & 116 & 45 & $2,067[2,019]$ & $21.70[21.00]$ & $5,927[6,294]$ & $62.22[65.50]$ & 0.9496 & $0.48[0.14]$ & $0.782[0.665]$ & 60.90 [20.82] \\
\hline \multicolumn{11}{|l|}{ Asia } \\
\hline Japan & 498 & 383 & $1,011[921]$ & $12.31[11.00]$ & $6,622[7,278]$ & 80.36 [88.00] & 0.8191 & $7.33[2.61]$ & $0.843[0.778]$ & 18.42 [15.38] \\
\hline South Korea & 100 & 91 & 803 [694] & 11.37 [9.00] & $4,383[4,466]$ & $62.39[62.00]$ & 0.7004 & $6.27[3.15]$ & $1.136[0.872]$ & 17.45 [13.49] \\
\hline \multicolumn{11}{|l|}{ MEA } \\
\hline Israel & 101 & 16 & $1,192[1,250]$ & $17.42[18.50]$ & $2,638[2,216]$ & $38.93[32.00]$ & 0.6831 & $1.02[0.22]$ & $0.864[0.746]$ & 43.74 [15.50] \\
\hline Turkey & 30 & 22 & 757 [762] & $14.88[14.50]$ & $1,884[1,780]$ & $37.38[35.00]$ & 0.5014 & $3.22[1.73]$ & $0.8357[0.725]$ & $12.95[8.72]$ \\
\hline \multicolumn{11}{|l|}{ Latin America } \\
\hline Chile & 40 & 23 & $1,015[1,011]$ & $12.64[12.00]$ & $2,950[2,974]$ & $36.35[36.00]$ & 0.8056 & 2.98 [1.67] & $0.960[0.625]$ & 25.76 [11.58] \\
\hline Mexico & 60 & 32 & $645[562]$ & $12.73[12.00]$ & $3,102[2,605]$ & $61.03[51.00]$ & 0.5049 & 22.97 [1.47] & $0.907[0.578]$ & $42.52[9.65]$ \\
\hline OECD civil code & 2,050 & 1,022 & $1,317[1,217]$ & $15.88[15.00]$ & $5,098[5,317]$ & $61.27[64.00]$ & 0.7949 & $25.48[1.28]$ & $0.854[0.688]$ & $35.33[12.60]$ \\
\hline OECD common law & 2,664 & 1,962 & $2,147[2,187]$ & $25.25[26.00]$ & $6,058[6,563]$ & 70.56 [77.90] & 0.8545 & $7.87[0.90]$ & $0.811[0.560]$ & $23.19[8.69]$ \\
\hline OECD excl. US & 3,214 & 1,912 & $1,678[1,842]$ & $19.42[21.00]$ & $5,434[6,014]$ & $63.63[70.00]$ & 0.8099 & $19.61[1.15]$ & $0.813[0.647]$ & 34.09 [10.60] \\
\hline US only & 1,500 & 1,072 & $2,187[2,215]$ & $26.54[27.00]$ & $6,093[6,510]$ & 72.78 [78.02] & 0.8380 & $6.68[0.88]$ & $0.863[0.551]$ & $16.27[8.69]$ \\
\hline OECD Overall & 4,714 & 2,984 & $1,877[2,045]$ & $22.20[24.00]$ & $5,645[6,311]$ & $66.56[75.00]$ & 0.8122 & $15.53[1.06]$ & $0.829[0.611]$ & $28.42[8.71]$ \\
\hline
\end{tabular}


Table 4 Factor mimicking portfolio summary statistics - for aggregate World market universe

This table reports the descriptive statistics, autocorrelations (at 1, 6 and 12 lags) for returns-based valuation factors including the Market, the Fama and French (1993) size (SMB) and book to market value (HML), the Jegadeesh and Titman (1993) momentum factor and the Liu (2006) liquidity factor used to explain cross section of stock returns across the market universe. The market universe in this case is the aggregate world and is equal-weighted. All factors are obtained from equal-weighted portfolios while the FF size (SMB)

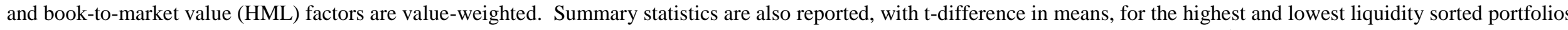

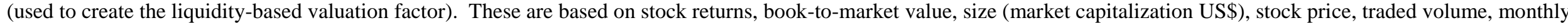
bid-ask spread and monthly percentage daily volatility in daily stock returns. Liquidity, Governance and Investor Protection portfolios D1 and D10 are formed from annual rebalancing. $\dagger, *, * *$ indicates significance at the $10 \%, 5 \%$, and $1 \%$ levels respectively

\begin{tabular}{|c|c|c|c|c|c|c|c|}
\hline & Market & SMB & HML & $\begin{array}{l}\text { Liquidity } \\
\text { (1 year) }\end{array}$ & Momentum & $\begin{array}{l}\text { Investor } \\
\text { Protection } \\
\text { (1 year) }\end{array}$ & $\begin{array}{l}\text { Governance } \\
\text { (1 year) }\end{array}$ \\
\hline & $\begin{array}{l}\text { Equal } \\
\text { weight }\end{array}$ & $\begin{array}{l}\text { Value } \\
\text { weight }\end{array}$ & $\begin{array}{l}\text { Value } \\
\text { weight }\end{array}$ & $\begin{array}{l}\text { Equal } \\
\text { weight }\end{array}$ & $\begin{array}{l}\text { Equal } \\
\text { weight }\end{array}$ & $\begin{array}{l}\text { Equal } \\
\text { weight }\end{array}$ & $\begin{array}{l}\text { Equal } \\
\text { weight }\end{array}$ \\
\hline \multicolumn{8}{|c|}{ Panel 1: Descriptive statistics OECD overall } \\
\hline Mean $(\%)$ & $1.12 \%$ & $1.86 \%$ & $0.03 \%$ & $-1.13 \%$ & $-0.12 \%$ & $0.15 \%$ & $0.19 \%$ \\
\hline t-statistic & $3.23 * *$ & $7.33 * *$ & 0.13 & $-4.56 * *$ & -0.34 & $1.88 \dagger$ & $1.92 *$ \\
\hline Standard Deviation (\%) & $4.92 \%$ & $3.59 \%$ & $3.18 \%$ & $3.52 \%$ & $5.03 \%$ & $2.48 \%$ & $2.94 \%$ \\
\hline Skewness & -0.67 & -0.42 & -0.03 & -2.62 & 2.05 & 2.47 & -0.08 \\
\hline Kurtosis & 6.20 & 4.65 & 4.64 & 23.71 & 12.35 & 22.62 & 3.86 \\
\hline Jarque-Bera statistic & 100.43 & 28.68 & 22.67 & $3,819.76$ & 873.25 & $3,429.58$ & 6.40 \\
\hline \multicolumn{8}{|c|}{ Panel 2: Pearson correlations OECD overall } \\
\hline Market & 1.000 & & & & & & \\
\hline SMB & $-0.424 * *$ & 1.000 & & & & & \\
\hline HML (Book to Market value) & $0.201 * *$ & $-0.155^{*}$ & 1.000 & & & & \\
\hline Liquidity (1 Year Rebalance) & $0.383 * *$ & $-0.335^{* *}$ & -0.011 & 1.000 & & & \\
\hline Momentum & $0.412 * *$ & $-0.458 * *$ & $0.128 *$ & $0.225 * *$ & 1.000 & & \\
\hline Investor Protection (1 Year Rebalance) & -0.028 & -0.024 & -0.044 & $0.101 \dagger$ & 0.069 & 1.000 & \\
\hline Governance (1 Year Rebalance) & -0.009 & 0.071 & 0.021 & -0.046 & $-0.114 *$ & $0.155^{*}$ & 1.000 \\
\hline \multicolumn{8}{|l|}{ Panel 3: Autocorrelations OECD overall } \\
\hline 1-Lag & 0.217 & 0.237 & 0.177 & -0.094 & 0.178 & 0.106 & 0.079 \\
\hline 6-Lags & -0.118 & -0.019 & 0.118 & -0.065 & 0.004 & -0.013 & 0.027 \\
\hline 12-Lags & 0.015 & 0.133 & 0.106 & 0.094 & 0.068 & 0.098 & 0.075 \\
\hline
\end{tabular}


Table 5 Factor mimicking portfolio summary statistics - for aggregate OECD market and US only universes

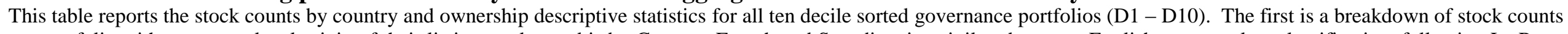

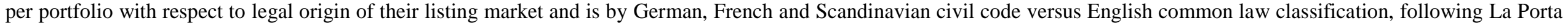

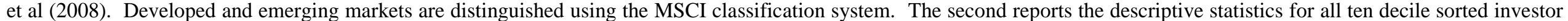

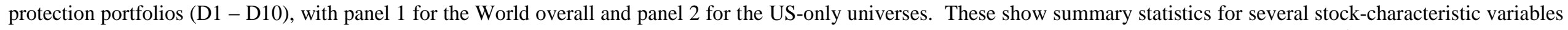

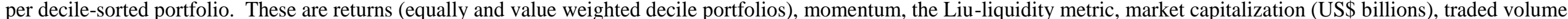

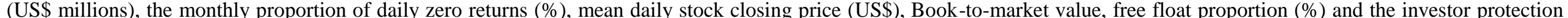

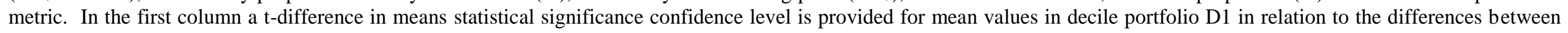
these and D10. $\dagger, * * *$ indicates significance at the $10 \%, 5 \%$, and $1 \%$ levels respectively.

\begin{tabular}{|c|c|c|c|c|c|c|c|c|c|c|}
\hline & D1 (Low) & D2 & D3 & D4 & D5 & D6 & D7 & D8 & D9 & D10 (High) \\
\hline \multicolumn{11}{|c|}{ Panel 1: Stock count (\#) - OECD universe } \\
\hline English common law & 7.32 & 18.39 & 65.56 & 119.74 & 152.57 & 169.90 & 184.70 & 185.37 & 192.56 & 191.95 \\
\hline Scandinavian civil code law & 1.43 & 6.16 & 17.15 & 16.96 & 14.71 & 10.03 & 6.92 & 6.27 & 5.88 & 5.33 \\
\hline French civil code law & 30.81 & 32.08 & 41.39 & 28.19 & 16.91 & 10.61 & 7.30 & 7.59 & 4.39 & 5.72 \\
\hline German civil code law & 181.04 & 150.93 & 70.12 & 26.92 & 12.72 & 6.01 & 2.07 & 2.36 & 0.96 & 0.36 \\
\hline North America & 2.01 & 7.69 & 34.67 & 82.14 & 103.83 & 114.56 & 134.03 & 134.81 & 139.99 & 145.45 \\
\hline Europe Developed & 13.05 & 40.46 & 106.72 & 95.41 & 80.24 & 75.27 & 57.51 & 54.14 & 49.51 & 41.25 \\
\hline Australasia & 0.00 & 2.07 & 10.18 & 13.53 & 19.03 & 16.77 & 16.38 & 19.07 & 18.59 & 20.74 \\
\hline Scandinavia & 1.43 & 6.16 & 17.15 & 16.96 & 14.71 & 10.03 & 6.92 & 6.27 & 5.88 & 5.33 \\
\hline Asia & 157.73 & 125.36 & 44.90 & 14.14 & 3.76 & 0.76 & 0.06 & 0.12 & 0.00 & 0.00 \\
\hline Latin America & 18.74 & 9.84 & 0.94 & 0.00 & 0.00 & 0.00 & 0.00 & 0.00 & 0.00 & 0.00 \\
\hline Europe Emerging & 6.67 & 8.29 & 5.27 & 1.18 & 0.54 & 0.18 & 0.06 & 0.00 & 0.00 & 0.00 \\
\hline Middle East \& Africa & 16.58 & 7.36 & 2.18 & 0.66 & 0.32 & 0.00 & 0.00 & 0.00 & 0.00 & 0.00 \\
\hline Total & 216.32 & 207.74 & 207.35 & 207.18 & 207.72 & 207.54 & 208.04 & 208.13 & 208.09 & 207.44 \\
\hline \multicolumn{11}{|c|}{ Panel 2: Stock count (\#) - US-only universe } \\
\hline S\&P 500 & 22.59 & 20.08 & 29.63 & 36.31 & 38.81 & 43.68 & 49.06 & 48.19 & 55.12 & 56.07 \\
\hline S\&P 400 & 26.30 & 31.15 & 24.07 & 28.90 & 22.85 & 21.93 & 21.04 & 20.48 & 17.13 & 15.10 \\
\hline S\&P 600 & 35.32 & 24.91 & 22.46 & 11.00 & 14.49 & 10.66 & 6.29 & 7.67 & 4.22 & 4.27 \\
\hline Total & 84.21 & 76.14 & 76.16 & 76.21 & 76.14 & 76.26 & 76.40 & 76.35 & 76.48 & 75.45 \\
\hline
\end{tabular}




\begin{tabular}{|c|c|c|c|c|c|c|c|c|c|c|}
\hline \multirow{2}{*}{$\begin{array}{l}\text { Panel 3: Summary statistics - OECD } \\
\text { market universe }\end{array}$} & D1 (Low) & D2 & D3 & D4 & D5 & D6 & D7 & D8 & D9 & D10 (High) \\
\hline & Equal & Equal & Equal & Equal & Equal & Equal & Equal & Equal & Equal & Equal \\
\hline Returns - equal weight, \% & 1.0783 & 1.0509 & 1.1385 & 1.2255 & 1.2258 & 1.2860 & 1.1936 & 1.0612 & 0.7802 & 1.2698 \\
\hline Returns - value weight, $\%$ & $0.2123 \dagger$ & 0.1377 & 0.2436 & 0.0087 & 0.6190 & -0.3496 & 1.0704 & -0.1423 & -0.4529 & 0.1647 \\
\hline Momentum & 0.0704 & 0.0382 & 0.0583 & 0.0660 & 0.0717 & 0.0661 & 0.0667 & 0.0628 & 0.0591 & 0.0595 \\
\hline Liu Liquidity (1 year) & $14.58 * *$ & 13.81 & 12.26 & 11.52 & 11.20 & 11.19 & 10.31 & 10.68 & 9.53 & 9.52 \\
\hline Traded volume (shares millions) & $54.93 * *$ & 74.04 & 44.50 & 40.98 & 52.69 & 59.69 & 57.33 & 61.78 & 85.87 & 137.17 \\
\hline Market Cap. (US\$ billions) & $75.74 * *$ & 40.67 & 30.97 & 39.17 & 41.14 & 10.40 & 11.80 & 18.26 & 19.41 & 41.50 \\
\hline Daily zero returns per month (\%) & $10.00 * *$ & 9.42 & 10.78 & 11.38 & 12.97 & 15.62 & 16.63 & 17.52 & 19.42 & 22.24 \\
\hline Price (mean month, US\$) & $404.99 * *$ & 101.76 & 246.31 & 157.33 & 147.97 & 57.81 & 40.93 & 39.52 & 37.50 & 42.46 \\
\hline Book to Market value ratio & $0.7227 * *$ & 0.7648 & 0.8774 & 0.8809 & 0.9370 & 0.9738 & 0.9598 & 0.8539 & 0.7060 & 0.9455 \\
\hline Free Float $(\%)$ & $66.52 * *$ & 69.33 & 67.19 & 66.26 & 67.47 & 70.10 & 70.65 & 72.43 & 74.33 & 76.03 \\
\hline Investor Protection metric & $5,096.93 * *$ & $5,614.14$ & $5,625.66$ & $5,600.26$ & $5,699.86$ & $5,958.42$ & $5,930.22$ & $6,124.00$ & $6,273.72$ & $6,475.82$ \\
\hline Firm governance index & $11.30 * *$ & 15.29 & 18.35 & 20.60 & 22.21 & 23.49 & 24.77 & 25.52 & 26.85 & 28.53 \\
\hline Governance metric & $844.02 * *$ & $1,241.94$ & $1,548.55$ & $1,761.24$ & $1,903.70$ & $2,024.05$ & $2,124.88$ & $2,200.66$ & $2,316.84$ & $2,474.15$ \\
\hline $\begin{array}{l}\text { Panel 4: Summary statistics - US only } \\
\text { universe }\end{array}$ & D1 (Low) & D2 & D3 & D4 & D5 & D6 & D7 & D8 & D9 & D10 (High) \\
\hline Returns - equal weight $(\%)$ & $1.2358 \dagger$ & 1.3401 & 1.2036 & 1.3398 & 1.0618 & 0.9857 & 1.0521 & 1.0258 & 0.9850 & 1.0665 \\
\hline Returns - value weight (\%) & 0.1032 & 0.9682 & 0.4755 & 0.7787 & 0.4494 & 0.3199 & 0.4136 & 0.0721 & 0.5747 & 0.0824 \\
\hline Momentum & 0.0727 & 0.0758 & 0.0729 & 0.0752 & 0.0615 & 0.0547 & 0.0545 & 0.0565 & 0.0535 & 0.0607 \\
\hline Liu Liquidity (1 year) & $11.05 * *$ & 10.29 & 10.01 & 10.12 & 10.29 & 9.59 & 9.50 & 9.46 & 9.25 & 9.28 \\
\hline Traded volume (shares millions) & $22.56 * *$ & 26.49 & 39.49 & 50.44 & 43.77 & 41.39 & 62.26 & 68.23 & 82.23 & 126.50 \\
\hline Market Cap. (US\$ billions) & $3.13 * *$ & 3.70 & 3.93 & 5.59 & 5.62 & 7.00 & 8.84 & 36.68 & 39.42 & 50.17 \\
\hline Daily zero returns per month (\%) & $14.99 * *$ & 15.73 & 20.27 & 21.84 & 23.50 & 25.72 & 29.67 & 28.38 & 33.56 & 35.16 \\
\hline Price (mean month, US\$) & $35.48 * *$ & 39.56 & 40.83 & 44.45 & 41.57 & 45.24 & 44.90 & 51.77 & 49.60 & 51.66 \\
\hline Book to Market value ratio & $0.8991 * *$ & 1.0643 & 1.3093 & 1.5774 & 1.0580 & 1.6600 & 0.9381 & -0.2490 & 1.7222 & 1.2830 \\
\hline Free Float $(\%)$ & $66.23 * *$ & 69.08 & 69.11 & 70.44 & 70.53 & 70.26 & 72.02 & 72.54 & 74.44 & 75.25 \\
\hline Investor Protection metric & $5,288.42 * *$ & $5,557.82$ & $5,583.84$ & $5,691.20$ & $5,691.98$ & $5,653.38$ & $5,848.10$ & $5,859.19$ & $6,069.92$ & $6,136.87$ \\
\hline Firm governance index & $21.13 * *$ & 23.21 & 24.23 & 25.00 & 25.76 & 26.28 & 27.10 & 27.77 & 28.62 & 30.10 \\
\hline Governance metric & $1,722.98 * *$ & $1,905.19$ & $1,994.02$ & $2,066.02$ & $2,135.42$ & $2,184.71$ & $2,256.31$ & $2,318.26$ & $2,395.57$ & $2,528.22$ \\
\hline
\end{tabular}


Table 6 Empirical results for 10 governance and investor protection (1 year rank and holding period) decile portfolios - for all universes

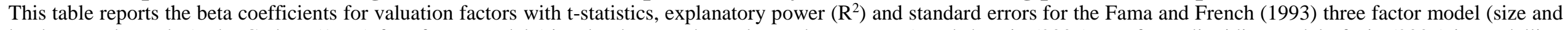

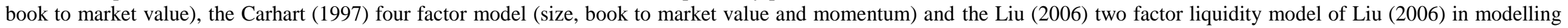

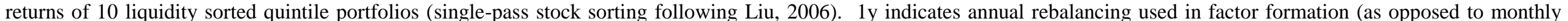

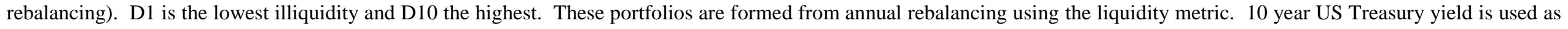

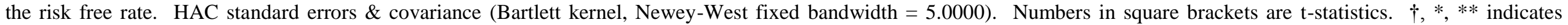
significance at the $10 \%, 5 \%$, and $1 \%$ levels respectively.

\begin{tabular}{|c|c|c|c|c|c|c|c|c|c|c|c|c|}
\hline Weighting: & $\begin{array}{l}\text { D1 } \\
\text { (Low) } \\
\text { Equal } \\
\end{array}$ & Equal & Equal & Equal & Equal & Equal & Equal & Equal & Equal & $\begin{array}{l}\text { D10 } \\
\text { (High) } \\
\text { Equal } \\
\end{array}$ & Equal & $\begin{array}{l}\text { D1 - D10 } \\
\text { Value }\end{array}$ \\
\hline \multicolumn{13}{|c|}{$\begin{array}{l}\text { Panel 1: OECD market universe } \\
\text { Panel 1A: CAPM }\end{array}$} \\
\hline Alpha $(\%)$ & $\begin{array}{l}-0.001 \\
{[-0.32]}\end{array}$ & $\begin{array}{l}-0.006 \\
{[-4.04]}\end{array}$ & $\begin{array}{l}-0.004 \\
{[-2.86]}\end{array}$ & $\begin{array}{l}-0.002 \\
{[-1.74]}\end{array}$ & $\begin{array}{l}-0.002 \\
{[-1.72]}\end{array}$ & $\begin{array}{l}-0.002 \\
{[-1.75]}\end{array}$ & $\begin{array}{l}-0.001 \\
{[-1.57]}\end{array}$ & $\begin{array}{l}-0.003 \\
{[-3.39]}\end{array}$ & $\begin{array}{l}-0.003 \\
{[-3.17]}\end{array}$ & $\begin{array}{l}-0.003 \\
{[-2.21]}\end{array}$ & $\begin{array}{l}0.002 \\
{[0.87]}\end{array}$ & $\begin{array}{l}-0.004 \\
{[-0.89]}\end{array}$ \\
\hline Beta: Market (excess return) & $\begin{array}{l}0.939 \\
{[22.08]}\end{array}$ & $\begin{array}{l}0.972 \\
{[21.58]}\end{array}$ & $\begin{array}{l}1.015 \\
{[24.63]}\end{array}$ & $\begin{array}{l}1.011 \\
{[27.84]}\end{array}$ & $\begin{array}{l}1.045 \\
{[53.99]}\end{array}$ & $\begin{array}{l}0.999 \\
{[38.9]}\end{array}$ & $\begin{array}{l}0.975 \\
{[59.06]}\end{array}$ & $\begin{array}{l}1.064 \\
{[46.83]}\end{array}$ & $\begin{array}{l}0.983 \\
{[35.53]}\end{array}$ & $\begin{array}{l}0.944 \\
{[28.83]}\end{array}$ & $\begin{array}{l}-0.005 \\
{[-0.11]}\end{array}$ & $\begin{array}{l}0.299 \\
{[3.41]}\end{array}$ \\
\hline Adjusted $\mathrm{R}^{2}$ & 0.7895 & 0.8393 & 0.9143 & 0.9221 & 0.9369 & 0.9252 & 0.9299 & 0.9321 & 0.9254 & 0.9079 & 0.0005 & 0.0531 \\
\hline \multicolumn{13}{|l|}{ Panel 1B: FF3F } \\
\hline Alpha $(\%)$ & $\begin{array}{l}-0.001 \\
{[-0.20]}\end{array}$ & $\begin{array}{l}-0.005 \\
{[-2.76]}\end{array}$ & $\begin{array}{l}-0.002 \\
{[-1.28]}\end{array}$ & $\begin{array}{l}-0.001 \\
{[-0.10]}\end{array}$ & $\begin{array}{l}-0.001 \\
{[-0.44]}\end{array}$ & $\begin{array}{l}-0.001 \\
{[-0.58]}\end{array}$ & $\begin{array}{l}-0.001 \\
{[-1.10]}\end{array}$ & $\begin{array}{l}-0.002 \\
{[-1.41]}\end{array}$ & $\begin{array}{l}-0.002 \\
{[-1.65]}\end{array}$ & $\begin{array}{l}-0.001 \\
{[-0.82]}\end{array}$ & $\begin{array}{l}0.001 \\
{[0.20]}\end{array}$ & $\begin{array}{l}-0.003 \\
{[-1.61]^{*}}\end{array}$ \\
\hline Beta: Market (excess return) & $\begin{array}{l}0.935 \\
{[21.08]}\end{array}$ & $\begin{array}{l}0.956 \\
{[19.73]}\end{array}$ & $\begin{array}{l}0.994 \\
{[23.50]}\end{array}$ & $\begin{array}{l}1.002 \\
{[26.91]}\end{array}$ & $\begin{array}{l}1.042 \\
{[52.17]}\end{array}$ & $\begin{array}{l}0.990 \\
{[32.91]}\end{array}$ & $\begin{array}{l}0.974 \\
{[49.57]}\end{array}$ & $\begin{array}{l}1.049 \\
{[46.62]}\end{array}$ & $\begin{array}{l}0.972 \\
{[33.22]}\end{array}$ & $\begin{array}{l}0.922 \\
{[33.82]}\end{array}$ & $\begin{array}{l}0.013 \\
{[0.28]}\end{array}$ & $\begin{array}{l}0.282 \\
{[3.09]}\end{array}$ \\
\hline Beta: SMB & $\begin{array}{l}-0.009 \\
{[-0.21]}\end{array}$ & $\begin{array}{l}-0.060 \\
{[-1.71]}\end{array}$ & $\begin{array}{l}-0.070 \\
{[-1.85]}\end{array}$ & $\begin{array}{l}-0.102 \\
{[-3.37]}\end{array}$ & $\begin{array}{l}-0.062 \\
{[-2.26]}\end{array}$ & $\begin{array}{l}-0.047 \\
{[-1.13]}\end{array}$ & $\begin{array}{l}-0.014 \\
{[-0.46]}\end{array}$ & $\begin{array}{l}-0.085 \\
{[-2.41]}\end{array}$ & $\begin{array}{l}-0.069 \\
{[-2.36]}\end{array}$ & $\begin{array}{l}-0.079 \\
{[-2.01]}\end{array}$ & $\begin{array}{l}0.070 \\
{[1.21]}\end{array}$ & $\begin{array}{l}-0.032 \\
{[-0.30]}\end{array}$ \\
\hline Beta: HML & $\begin{array}{l}0.009 \\
{[0.19]}\end{array}$ & $\begin{array}{l}-0.020 \\
{[-0.39]}\end{array}$ & $\begin{array}{l}-0.006 \\
{[-0.12]}\end{array}$ & $\begin{array}{l}-0.172 \\
{[-4.71]}\end{array}$ & $\begin{array}{l}-0.123 \\
{[-3.51]}\end{array}$ & $\begin{array}{l}-0.047 \\
{[-0.86]}\end{array}$ & $\begin{array}{l}-0.028 \\
{[-0.94]}\end{array}$ & $\begin{array}{l}-0.094 \\
{[-1.94]}\end{array}$ & $\begin{array}{l}-0.074 \\
{[-1.82]}\end{array}$ & $\begin{array}{l}-0.019 \\
{[-0.4]}\end{array}$ & $\begin{array}{l}0.028 \\
{[0.37]}\end{array}$ & $\begin{array}{l}0.054 \\
{[0.41]}\end{array}$ \\
\hline Adjusted $\mathrm{R}^{2}$ & 0.7874 & 0.8392 & 0.9153 & 0.9353 & 0.9426 & 0.9261 & 0.9296 & 0.9366 & 0.9284 & 0.9098 & 0.0086 & 0.0446 \\
\hline \multicolumn{13}{|l|}{ Panel 1C: Carhart 4F } \\
\hline Alpha $(\%)$ & $\begin{array}{l}0.001 \\
{[0.01]}\end{array}$ & $\begin{array}{l}-0.005 \\
{[-2.87]}\end{array}$ & $\begin{array}{l}-0.002 \\
{[-1.32]}\end{array}$ & $\begin{array}{l}-0.001 \\
{[-0.07]}\end{array}$ & $\begin{array}{l}-0.001 \\
{[-0.47]}\end{array}$ & $\begin{array}{l}-0.001 \\
{[-0.44]}\end{array}$ & $\begin{array}{l}-0.001 \\
{[-1.04]}\end{array}$ & $\begin{array}{l}-0.002 \\
{[-1.39]}\end{array}$ & $\begin{array}{l}-0.002 \\
{[-1.63]}\end{array}$ & $\begin{array}{l}-0.001 \\
{[-0.74]}\end{array}$ & $\begin{array}{l}\mathbf{0 . 0 0 1} \\
{[1.34] \dagger}\end{array}$ & $\begin{array}{l}-0.002 \\
{[-1.46] \dagger}\end{array}$ \\
\hline Beta: Market (excess return) & $\begin{array}{l}0.958 \\
{[18.56]}\end{array}$ & $\begin{array}{l}0.948 \\
{[17.52]}\end{array}$ & $\begin{array}{l}0.991 \\
{[23.00]}\end{array}$ & $\begin{array}{l}1.004 \\
{[25.88]}\end{array}$ & $\begin{array}{l}1.041 \\
{[50.60]}\end{array}$ & $\begin{array}{l}1.001 \\
{[34.80]}\end{array}$ & $\begin{array}{l}0.977 \\
{[47.34]}\end{array}$ & $\begin{array}{l}1.049 \\
{[46.77]}\end{array}$ & $\begin{array}{l}0.971 \\
{[37.96]}\end{array}$ & $\begin{array}{l}0.926 \\
{[34.81]}\end{array}$ & $\begin{array}{l}0.032 \\
{[0.57]}\end{array}$ & $\begin{array}{l}0.323 \\
{[3.48]}\end{array}$ \\
\hline Beta: SMB & $\begin{array}{l}-0.050 \\
{[-1.01]}\end{array}$ & $\begin{array}{l}-0.045 \\
{[-1.25]}\end{array}$ & $\begin{array}{l}-0.064 \\
{[-1.75]}\end{array}$ & $\begin{array}{l}-0.106 \\
{[-3.67]}\end{array}$ & $\begin{array}{l}-0.060 \\
{[-2.06]}\end{array}$ & $\begin{array}{l}-0.064 \\
{[-1.43]}\end{array}$ & $\begin{array}{l}-0.018 \\
{[-0.58]}\end{array}$ & $\begin{array}{l}-0.084 \\
{[-2.42]}\end{array}$ & $\begin{array}{l}-0.068 \\
{[-2.06]}\end{array}$ & $\begin{array}{l}-0.086 \\
{[-2.02]}\end{array}$ & $\begin{array}{l}0.036 \\
{[0.55]}\end{array}$ & $\begin{array}{l}-0.105 \\
{[-0.84]}\end{array}$ \\
\hline Beta: HML & $\begin{array}{l}0.012 \\
{[0.26]}\end{array}$ & $\begin{array}{l}-0.021 \\
{[-0.41]}\end{array}$ & $\begin{array}{l}-0.007 \\
{[-0.13]}\end{array}$ & $\begin{array}{l}-0.172 \\
{[-4.65]}\end{array}$ & $\begin{array}{l}-0.123 \\
{[-3.49]}\end{array}$ & $\begin{array}{l}-0.046 \\
{[-0.84]}\end{array}$ & $\begin{array}{l}-0.027 \\
{[-0.93]}\end{array}$ & $\begin{array}{l}-0.094 \\
{[-1.93]}\end{array}$ & $\begin{array}{l}-0.074 \\
{[-1.79]}\end{array}$ & $\begin{array}{l}-0.019 \\
{[-0.39]}\end{array}$ & $\begin{array}{l}0.031 \\
{[0.40]}\end{array}$ & $\begin{array}{l}0.060 \\
{[0.45]}\end{array}$ \\
\hline Beta: Momentum & -0.085 & 0.031 & 0.013 & -0.008 & 0.004 & -0.036 & -0.009 & 0.002 & 0.002 & -0.015 & -0.070 & -0.151 \\
\hline
\end{tabular}




\begin{tabular}{|c|c|c|c|c|c|c|c|c|c|c|c|c|}
\hline \multirow[b]{2}{*}{ Adjusted $\mathrm{R}^{2}$} & {$[-1.87]$} & {$[0.72]$} & {$[0.56]$} & {$[-0.27]$} & {$[0.18]$} & {$[-1.12]$} & {$[-0.36]$} & {$[0.08]$} & {$[0.06]$} & {$[-0.41]$} & {$[-1.34]$} & {$[-1.2]$} \\
\hline & 0.7915 & 0.8390 & 0.9150 & 0.9350 & 0.9424 & 0.9266 & 0.9293 & 0.9363 & 0.9281 & 0.9095 & 0.0029 & 0.0512 \\
\hline \multicolumn{13}{|l|}{ Panel 1D: Liquidity 2F(1y) } \\
\hline \multirow{2}{*}{ Alpha $(\%)$} & -0.001 & -0.004 & -0.001 & 0.001 & 0.001 & -0.001 & -0.001 & -0.002 & -0.002 & -0.001 & 0.001 & -0.007 \\
\hline & {$[-0.04]$} & {$[-2.60]$} & {$[-1.05]$} & {$[0.11]$} & {$[0.89]$} & {$[-0.42]$} & {$[-0.31]$} & {$[-1.76]$} & {$[-1.80]$} & {$[-1.14]$} & {$[1.60]^{*}$} & {$[-1.63]^{*}$} \\
\hline \multirow[t]{2}{*}{ Beta: Market (excess return) } & 0.929 & 0.943 & 0.976 & 0.967 & 0.999 & 0.974 & 0.953 & 1.034 & 0.959 & 0.922 & 0.006 & 0.368 \\
\hline & [20.51] & [20.99] & [25.87] & [31.71] & [59.97] & [39.01] & [63.36] & [49.06] & [37.41] & [28.97] & {$[0.13]$} & [4.04] \\
\hline \multirow[t]{2}{*}{ Beta: Liquidity } & 0.036 & 0.105 & 0.145 & 0.161 & 0.171 & 0.091 & 0.080 & 0.109 & 0.088 & 0.078 & -0.042 & -0.253 \\
\hline & {$[0.81]$} & {$[1.96]$} & [3.19] & {$[3.74]$} & [5.29] & {$[3.46]$} & {$[2.80]$} & [2.91] & {$[2.55]$} & [2.29] & {$[-0.71]$} & {$[-1.45]$} \\
\hline Adjusted $\mathrm{R}^{2}$ & 0.789 & 0.8428 & 0.9221 & 0.932 & 0.9477 & 0.9282 & 0.9324 & 0.9361 & 0.9282 & 0.9101 & 0.0079 & 0.0666 \\
\hline \multicolumn{13}{|c|}{ Panel 1E: Investor Protection 2F(1y) } \\
\hline \multirow[t]{2}{*}{ Alpha $(\%)$} & -0.001 & -0.006 & -0.004 & -0.002 & -0.002 & -0.002 & -0.001 & -0.003 & -0.003 & -0.002 & 0.002 & -0.004 \\
\hline & {$[-0.37]$} & {$[-4.26]$} & {$[-2.84]$} & {$[-1.66]$} & {$[-1.57]$} & {$[-1.41]$} & {$[-1.24]$} & {$[-2.98]$} & {$[-2.79]$} & {$[-1.95]$} & {$[1.73]^{* *}$} & {$[-1.91] * *$} \\
\hline \multirow[t]{2}{*}{ Beta: Market (excess return) } & 0.939 & 0.974 & 1.015 & 1.011 & 1.045 & 0.997 & 0.973 & 1.061 & 0.982 & 0.942 & -0.003 & 0.301 \\
\hline & [21.97] & {$[21.71]$} & {$[24.57]$} & [27.64] & [53.06] & [40.09] & [61.31] & [48.47] & [36.57] & [30.13] & {$[-0.06]$} & {$[3.40]$} \\
\hline \multirow[t]{2}{*}{ Beta: Investor Protect } & 0.053 & 0.126 & 0.011 & -0.016 & -0.045 & -0.125 & -0.141 & -0.154 & -0.108 & -0.130 & 0.184 & 0.150 \\
\hline & {$[0.66]$} & {$[1.95]$} & {$[0.19]$} & {$[-0.31]$} & {$[-1.07]$} & {$[-2.60]$} & {$[-3.21]$} & {$[-3.51]$} & {$[-2.67]$} & {$[-2.66]$} & {$[1.70]$} & {$[0.71]$} \\
\hline Adjusted $\mathrm{R}^{2}$ & 0.7891 & 0.8421 & 0.9139 & 0.9218 & 0.9371 & 0.9286 & 0.9347 & 0.9368 & 0.9279 & 0.9119 & 0.0142 & 0.0520 \\
\hline \multicolumn{13}{|l|}{ Panel 1F: Governance $2 F(1 y)$} \\
\hline \multirow[t]{2}{*}{ Alpha $(\%)$} & -0.002 & -0.007 & -0.004 & -0.002 & -0.001 & -0.001 & -0.001 & -0.003 & -0.003 & -0.002 & -- -- & ---- \\
\hline & {$[-1.07]$} & {$[-4.27]$} & {$[-2.14]$} & {$[-1.57]$} & {$[-1.53]$} & {$[-1.42]$} & {$[-1.18]$} & {$[-2.03]$} & {$[-1.86]$} & {$[-1.07]$} & & \\
\hline \multirow[t]{2}{*}{ Beta: Market (excess return) } & 0.942 & 0.974 & 1.016 & 1.011 & 1.045 & 0.998 & 0.974 & 1.062 & 0.982 & 0.942 & -- -- & -- -- \\
\hline & [32.27] & {$[27.01]$} & {$[24.74]$} & [28.16] & [54.66] & {$[41.10]$} & {$[63.46]$} & [46.29] & [35.01] & [32.27] & & \\
\hline \multirow[t]{2}{*}{ Beta: Governance } & 0.700 & 0.347 & 0.098 & -0.086 & -0.146 & -0.181 & -0.194 & -0.236 & -0.217 & -0.300 & ---- & -- -- \\
\hline & [21.72] & {$[6.07]$} & {$[2.89]$} & {$[-2.15]$} & {$[-4.21]$} & {$[-4.69]$} & {$[-6.56]$} & {$[-7.36]$} & {$[-8.12]$} & {$[-9.30]$} & & \\
\hline Adjusted $\mathrm{R}^{2}$ & 0.9477 & 0.8771 & 0.9169 & 0.9241 & 0.9432 & 0.9358 & 0.9430 & 0.9484 & 0.9413 & 0.9406 & ---- & -- -- \\
\hline \multicolumn{13}{|c|}{ Panel 1G: Governance 2F(1y) using Investor Protection deciles } \\
\hline \multirow[t]{2}{*}{ Alpha $(\%)$} & 0.001 & -0.001 & -0.001 & -0.001 & 0.001 & -0.001 & 0.001 & -0.001 & 0.001 & -0.001 & 0.001 & -0.004 \\
\hline & {$[0.62]$} & {$[-0.52]$} & {$[-1.59]$} & {$[-0.11]$} & {$[0.14]$} & {$[-0.24]$} & {$[0.92]$} & {$[-0.05]$} & {$[0.01]$} & {$[-0.51]$} & {$[0.84]$} & {$[-0.42]$} \\
\hline \multirow[t]{2}{*}{ Beta: Market (excess return) } & 1.064 & 1.084 & 1.046 & 1.048 & 1.016 & 0.972 & 0.918 & 0.893 & 0.906 & 1.077 & -0.014 & -0.152 \\
\hline & [29.27] & [57.65] & [64.88] & [49.63] & [54.83] & [67.72] & [62.56] & [46.44] & [44.45] & [53.82] & {$[-0.34]$} & {$[-0.66]$} \\
\hline \multirow[t]{2}{*}{ Beta: Governance } & 0.130 & 0.101 & 0.034 & -0.063 & -0.137 & -0.136 & -0.073 & 0.040 & 0.086 & -0.001 & 0.131 & 0.726 \\
\hline & [2.52] & {$[2.08]$} & {$[1.16]$} & {$[-2.48]$} & {$[-4.77]$} & {$[-4.76]$} & {$[-2.11]$} & [1.18] & {$[2.34]$} & {$[-0.02]$} & {$[2.40]$} & {$[1.37]$} \\
\hline Adjusted $\mathrm{R}^{2}$ & 0.8623 & 0.8414 & 0.9702 & 0.9538 & 0.9602 & 0.9613 & 0.9502 & 0.9311 & 0.9357 & 0.9460 & 0.0150 & 0.0180 \\
\hline
\end{tabular}

Panel 2: OECD (excluding US) markets universe 
Panel 2A: CAPM

\begin{tabular}{|c|c|c|c|c|c|c|c|c|c|c|c|c|}
\hline Alpha $(\%)$ & $\begin{array}{l}0.001 \\
{[0.36]}\end{array}$ & $\begin{array}{l}-0.004 \\
{[-2.44]}\end{array}$ & $\begin{array}{l}-0.005 \\
{[-3.14]}\end{array}$ & $\begin{array}{l}-0.004 \\
{[-2.38]}\end{array}$ & $\begin{array}{l}-0.003 \\
{[-1.89]}\end{array}$ & $\begin{array}{l}-0.001 \\
{[-0.58]}\end{array}$ & $\begin{array}{l}-0.002 \\
{[-1.77]}\end{array}$ & $\begin{array}{l}-0.002 \\
{[-1.55]}\end{array}$ & $\begin{array}{l}-0.002 \\
{[-2.23]}\end{array}$ & $\begin{array}{l}-0.003 \\
{[-2.83]}\end{array}$ & $\begin{array}{l}0.004 \\
{[1.57] \dagger}\end{array}$ & $\begin{array}{l}-0.006 \\
{[-1.44] \dagger}\end{array}$ \\
\hline Beta: Market (excess return) & $\begin{array}{l}0.946 \\
{[22.28]}\end{array}$ & $\begin{array}{l}0.919 \\
{[17.52]}\end{array}$ & $\begin{array}{l}0.956 \\
{[20.43]}\end{array}$ & $\begin{array}{l}1.014 \\
{[18.18]}\end{array}$ & $\begin{array}{l}0.961 \\
{[20.55]}\end{array}$ & $\begin{array}{l}1.014 \\
{[26.20]}\end{array}$ & $\begin{array}{l}1.063 \\
{[53.37]}\end{array}$ & $\begin{array}{l}1.084 \\
{[29.84]}\end{array}$ & $\begin{array}{l}1.025 \\
{[39.99]}\end{array}$ & $\begin{array}{l}1.023 \\
{[36.05]}\end{array}$ & $\begin{array}{l}-0.077 \\
{[-1.64]}\end{array}$ & $\begin{array}{l}0.327 \\
{[3.54]}\end{array}$ \\
\hline Adjusted $\mathrm{R}^{2}$ & 0.7727 & 0.7893 & 0.8357 & 0.8751 & 0.8828 & 0.9161 & 0.9210 & 0.8962 & 0.9058 & 0.9085 & 0.0102 & 0.0684 \\
\hline \multicolumn{13}{|l|}{ Panel 2B: FF3F } \\
\hline Alpha $(\%)$ & $\begin{array}{l}0.001 \\
{[0.34]}\end{array}$ & $\begin{array}{l}-0.003 \\
{[-1.85]}\end{array}$ & $\begin{array}{l}-0.004 \\
{[-2.16]}\end{array}$ & $\begin{array}{l}-0.002 \\
{[-0.86]}\end{array}$ & $\begin{array}{l}-0.001 \\
{[-0.42]}\end{array}$ & $\begin{array}{l}0.001 \\
{[0.32]}\end{array}$ & $\begin{array}{l}-0.001 \\
{[-0.96]}\end{array}$ & $\begin{array}{l}0.001 \\
{[0.24]}\end{array}$ & $\begin{array}{l}-0.001 \\
{[-1.22]}\end{array}$ & $\begin{array}{l}-0.002 \\
{[-1.32]}\end{array}$ & $\begin{array}{l}0.002 \\
{[1.94]^{* *}}\end{array}$ & $\begin{array}{l}-0.003 \\
{[-1.75]^{* *}}\end{array}$ \\
\hline Beta: Market (excess return) & $\begin{array}{l}0.957 \\
{[23.46]}\end{array}$ & $\begin{array}{l}0.913 \\
{[18.55]}\end{array}$ & $\begin{array}{l}0.947 \\
{[18.23]}\end{array}$ & $\begin{array}{l}0.984 \\
{[16.8]}\end{array}$ & $\begin{array}{l}0.935 \\
{[18.88]}\end{array}$ & $\begin{array}{l}1.003 \\
{[23.8]}\end{array}$ & $\begin{array}{l}1.061 \\
{[50.14]}\end{array}$ & $\begin{array}{l}1.061 \\
{[29.26]}\end{array}$ & $\begin{array}{l}1.019 \\
{[35.56]}\end{array}$ & $\begin{array}{l}1.000 \\
{[43.38]}\end{array}$ & $\begin{array}{l}-0.044 \\
{[-1.00]}\end{array}$ & $\begin{array}{l}0.293 \\
{[3.47]}\end{array}$ \\
\hline Beta: SMB & $\begin{array}{l}0.002 \\
{[0.06]}\end{array}$ & $\begin{array}{l}-0.058 \\
{[-1.54]}\end{array}$ & $\begin{array}{l}-0.032 \\
{[-0.85]}\end{array}$ & $\begin{array}{l}-0.097 \\
{[-2.68]}\end{array}$ & $\begin{array}{l}-0.091 \\
{[-2.52]}\end{array}$ & $\begin{array}{l}-0.052 \\
{[-1.36]}\end{array}$ & $\begin{array}{l}-0.031 \\
{[-0.91]}\end{array}$ & $\begin{array}{l}-0.101 \\
{[-2.92]}\end{array}$ & $\begin{array}{l}-0.045 \\
{[-1.51]}\end{array}$ & $\begin{array}{l}-0.070 \\
{[-1.91]}\end{array}$ & $\begin{array}{l}0.073 \\
{[1.62]}\end{array}$ & $\begin{array}{l}-0.130 \\
{[-1.27]}\end{array}$ \\
\hline Beta: HML & $\begin{array}{l}-0.091 \\
{[-2.36]}\end{array}$ & $\begin{array}{l}-0.112 \\
{[-2.21]}\end{array}$ & $\begin{array}{l}-0.011 \\
{[-0.23]}\end{array}$ & $\begin{array}{l}-0.010 \\
{[-0.22]}\end{array}$ & $\begin{array}{l}-0.027 \\
{[-0.55]}\end{array}$ & $\begin{array}{l}-0.050 \\
{[-0.96]}\end{array}$ & $\begin{array}{l}-0.062 \\
{[-1.77]}\end{array}$ & $\begin{array}{l}-0.080 \\
{[-1.94]}\end{array}$ & $\begin{array}{l}-0.071 \\
{[-1.44]}\end{array}$ & $\begin{array}{l}0.004 \\
{[0.08]}\end{array}$ & $\begin{array}{l}-0.094 \\
{[-1.48]}\end{array}$ & $\begin{array}{l}-0.064 \\
{[-0.57]}\end{array}$ \\
\hline Adjusted $\mathrm{R}^{2}$ & 0.7739 & 0.7949 & 0.8347 & 0.8786 & 0.8868 & 0.9179 & 0.9222 & 0.9023 & 0.9081 & 0.9101 & 0.0184 & 0.0674 \\
\hline \multicolumn{13}{|l|}{ Panel 2C: Carhart 4F } \\
\hline Alpha $(\%)$ & $\begin{array}{l}0.001 \\
{[0.35]}\end{array}$ & $\begin{array}{l}-0.003 \\
{[-1.86]}\end{array}$ & $\begin{array}{l}-0.004 \\
{[-2.16]}\end{array}$ & $\begin{array}{l}-0.002 \\
{[-0.87]}\end{array}$ & $\begin{array}{l}-0.001 \\
{[-0.42]}\end{array}$ & $\begin{array}{l}0.001 \\
{[0.32]}\end{array}$ & $\begin{array}{l}-0.001 \\
{[-0.97]}\end{array}$ & $\begin{array}{l}0.001 \\
{[0.24]}\end{array}$ & $\begin{array}{l}-0.001 \\
{[-1.23]}\end{array}$ & $\begin{array}{l}-0.002 \\
{[-1.32]}\end{array}$ & $\begin{array}{l}0.002 \\
{[1.97]^{* *}}\end{array}$ & $\begin{array}{l}-0.003 \\
{[-1.74]^{* *}}\end{array}$ \\
\hline Beta: Market (excess return) & $\begin{array}{l}0.981 \\
{[21.62]}\end{array}$ & $\begin{array}{l}0.909 \\
{[16.87]}\end{array}$ & $\begin{array}{l}0.946 \\
{[17.20]}\end{array}$ & $\begin{array}{l}0.971 \\
{[17.22]}\end{array}$ & $\begin{array}{l}0.934 \\
{[18.46]}\end{array}$ & $\begin{array}{l}1.009 \\
{[23.09]}\end{array}$ & $\begin{array}{l}1.058 \\
{[45.44]}\end{array}$ & $\begin{array}{l}1.059 \\
{[30.89]}\end{array}$ & $\begin{array}{l}1.013 \\
{[36.47]}\end{array}$ & $\begin{array}{l}1.000 \\
{[47.19]}\end{array}$ & $\begin{array}{l}-0.019 \\
{[-0.41]}\end{array}$ & $\begin{array}{l}0.303 \\
{[3.42]}\end{array}$ \\
\hline Beta: SMB & $\begin{array}{l}-0.041 \\
{[-0.89]}\end{array}$ & $\begin{array}{l}-0.051 \\
{[-1.33]}\end{array}$ & $\begin{array}{l}-0.03 \\
{[-0.76]}\end{array}$ & $\begin{array}{l}-0.073 \\
{[-2.03]}\end{array}$ & $\begin{array}{l}-0.089 \\
{[-2.71]}\end{array}$ & $\begin{array}{l}-0.063 \\
{[-1.71]}\end{array}$ & $\begin{array}{l}-0.025 \\
{[-0.72]}\end{array}$ & $\begin{array}{l}-0.097 \\
{[-2.78]}\end{array}$ & $\begin{array}{l}-0.035 \\
{[-1.17]}\end{array}$ & $\begin{array}{l}-0.070 \\
{[-2.16]}\end{array}$ & $\begin{array}{l}0.029 \\
{[1.55]}\end{array}$ & $\begin{array}{l}-0.148 \\
{[-1.45]}\end{array}$ \\
\hline Beta: HML & $\begin{array}{l}-0.085 \\
{[-2.35]}\end{array}$ & $\begin{array}{l}-0.113 \\
{[-2.21]}\end{array}$ & $\begin{array}{l}-0.011 \\
{[-0.23]}\end{array}$ & $\begin{array}{l}-0.013 \\
{[-0.28]}\end{array}$ & $\begin{array}{l}-0.027 \\
{[-0.54]}\end{array}$ & $\begin{array}{l}-0.049 \\
{[-0.93]}\end{array}$ & $\begin{array}{l}-0.062 \\
{[-1.76]}\end{array}$ & $\begin{array}{l}-0.081 \\
{[-1.91]}\end{array}$ & $\begin{array}{l}-0.073 \\
{[-1.43]}\end{array}$ & $\begin{array}{l}0.004 \\
{[0.08]}\end{array}$ & $\begin{array}{l}-0.088 \\
{[-1.37]}\end{array}$ & $\begin{array}{l}-0.061 \\
{[-0.55]}\end{array}$ \\
\hline Beta: Momentum & $\begin{array}{l}-0.100 \\
{[-2.07]}\end{array}$ & $\begin{array}{l}0.015 \\
{[0.32]}\end{array}$ & $\begin{array}{l}0.006 \\
{[0.15]}\end{array}$ & $\begin{array}{l}0.054 \\
{[1.29]}\end{array}$ & $\begin{array}{l}0.005 \\
{[0.11]}\end{array}$ & $\begin{array}{l}-0.025 \\
{[-0.76]}\end{array}$ & $\begin{array}{l}0.012 \\
{[0.37]}\end{array}$ & $\begin{array}{l}0.009 \\
{[0.22]}\end{array}$ & $\begin{array}{l}0.022 \\
{[0.60]} \\
\end{array}$ & $\begin{array}{l}0.001 \\
{[0.02]}\end{array}$ & $\begin{array}{l}-0.101 \\
{[-1.88]}\end{array}$ & $\begin{array}{l}-0.041 \\
{[-0.46]}\end{array}$ \\
\hline Adjusted $\mathrm{R}^{2}$ & 0.7785 & 0.7940 & 0.8339 & 0.8796 & 0.8862 & 0.9179 & 0.9219 & 0.9019 & 0.9079 & 0.9097 & 0.0307 & 0.0634 \\
\hline \multicolumn{13}{|l|}{ Panel 2D: Liquidity 2F (1y) } \\
\hline Alpha $(\%)$ & $\begin{array}{l}0.002 \\
{[1.95]}\end{array}$ & $\begin{array}{l}-0.002 \\
{[-1.36]}\end{array}$ & $\begin{array}{l}-0.003 \\
{[-1.70]}\end{array}$ & $\begin{array}{l}-0.002 \\
{[-1.94]}\end{array}$ & $\begin{array}{l}0.001 \\
{[-0.02]}\end{array}$ & $\begin{array}{l}0.001 \\
{[1.09]}\end{array}$ & $\begin{array}{l}0.001 \\
{[1.35]}\end{array}$ & $\begin{array}{l}0.001 \\
{[0.06]}\end{array}$ & $\begin{array}{l}-0.001 \\
{[-1.05]}\end{array}$ & $\begin{array}{l}-0.002 \\
{[-1.34]}\end{array}$ & $\begin{array}{l}0.004 \\
{[1.41] \dagger}\end{array}$ & $\begin{array}{l}-0.007 \\
{[-1.43] \dagger}\end{array}$ \\
\hline Beta: Market (excess return) & $\begin{array}{l}0.924 \\
{[21.76]}\end{array}$ & $\begin{array}{l}0.882 \\
{[18.77]}\end{array}$ & $\begin{array}{l}0.924 \\
{[19.28]}\end{array}$ & $\begin{array}{l}0.973 \\
{[19.09]}\end{array}$ & $\begin{array}{l}0.915 \\
{[21.05]}\end{array}$ & $\begin{array}{l}0.979 \\
{[26.83]}\end{array}$ & $\begin{array}{l}1.030 \\
{[50.75]}\end{array}$ & $\begin{array}{l}1.050 \\
{[32.87]}\end{array}$ & $\begin{array}{l}1.004 \\
{[36.70]}\end{array}$ & $\begin{array}{l}0.997 \\
{[38.72]}\end{array}$ & $\begin{array}{l}-0.073 \\
{[-1.49]}\end{array}$ & $\begin{array}{l}0.333 \\
{[3.60]}\end{array}$ \\
\hline Beta: Liquidity & $\begin{array}{l}0.084 \\
{[2.87]}\end{array}$ & $\begin{array}{l}0.143 \\
{[3.22]}\end{array}$ & $\begin{array}{l}0.129 \\
{[3.53]}\end{array}$ & $\begin{array}{l}0.160 \\
{[3.49]}\end{array}$ & $\begin{array}{l}0.181 \\
{[2.74]}\end{array}$ & $\begin{array}{l}0.140 \\
{[3.10]}\end{array}$ & $\begin{array}{l}0.134 \\
{[4.77]}\end{array}$ & $\begin{array}{l}0.136 \\
{[3.26]}\end{array}$ & $\begin{array}{l}0.081 \\
{[3.28]}\end{array}$ & $\begin{array}{l}0.103 \\
{[3.99]}\end{array}$ & $\begin{array}{l}-0.018 \\
{[-0.45]}\end{array}$ & $\begin{array}{l}-0.024 \\
{[-0.23]}\end{array}$ \\
\hline Adjusted $\mathrm{R}^{2}$ & 0.7760 & 0.8021 & 0.8459 & 0.8903 & 0.9050 & 0.9284 & 0.9311 & 0.9059 & 0.9094 & 0.9147 & 0.0058 & 0.064 \\
\hline
\end{tabular}


Panel 2E: Investor Protection 2F (1y)

Alpha (\%)

0.001

$-0.005 \quad-0.005$

$-0.004$

$-0.003$

0.001

$-0.001$

$-0.001$

$-0.002$

$-0.003$

0.003

Beta: Market (excess return)

0.959

0.934

$[-3.20] \quad[-2.39] \quad[-1.72]$

[-0.22]

[-1.21]

[-1.08]

[-1.67]

[-2.36]

0.992

$-0.033$

$[-1.69]^{* *}$

Beta: Investor Protect

$[22.69]$
0.122

[17.71]

[21.05]

[18.28] [20.57]

[26.13]

[53.01]

[38.00]

$[-0.72]$

0.392

$\begin{array}{lllll}{[1.62]} & {[1.52]} & {[-0.33]} & {[-0.24]} & {[-1.73]}\end{array}$

Adjusted $\mathrm{R}^{2}$

0.7739

0.8350

0.8745

0.8837

$[-4.10]$

$-0.214$

[42.08]

$-0.281$

[4.02]

Panel 2F: Governance 2F(1y)

Alpha (\%)

Beta: Market (excess return)

$\begin{array}{lllll}-0.002 & -0.006 & -0.005 & -0.004 & -0.002\end{array}$

0.9221

$0.9275 \quad[-3.44]$

$[-5.63]$

0.9207

[4.49] [2.78]

$0.0812 \quad 0.1086$

$\begin{array}{llllll}-0.001 & -0.001 & -0.001 & -0.002 & -0.002\end{array}$

$\begin{array}{llllllllll}{[-1.18]} & {[-1.71]} & {[-1.89]} & {[-1.54]} & {[-1.52]} & {[-0.06]} & {[-1.18]} & {[-1.03]} & {[-1.58]} & {[-1.18]}\end{array}$

1.000

0.944

0.969

1.018

0.951

1.001

1.052

1.073

1.009

1.000

$\begin{array}{lllll}0.702 & 0.328 & 0.158 & 0.052 & -0.134\end{array}$

Beta: Governance

$\begin{array}{llllllllll}{[21.65]} & {[5.43]} & {[2.75]} & {[1.56]} & {[-3.84]} & {[-5.15]} & {[-4.09]} & {[-3.65]} & {[-4.83]} & {[-9.20]}\end{array}$

$[-3.84$

[27.65]

[55.93]

[28.59]

[38.64]

[38.65]

Adjusted R ${ }^{2}$

$0.9386 \quad 0.8278$

0.9254

0.9278

0.9024

$0.9199 \quad 0.9384$

$---$

$----$

Panel 2G: Governance 2F(1y) using Investor Protection deciles

Alpha (\%)

$\begin{array}{lll}0.002 & 0.001 & 0.001\end{array}$

$-0.001--0.001$

$\begin{array}{lll}0.46] & {[0.59]} & {[0.60]} \\ 0.968 & 1.173 & 1.038\end{array}$

Beta: Market (excess return)

[46.51] $\quad[24.49] \quad[35.31]$

$[-1.76]$

$-0.001$

$-0.001$

$-0.001 \quad-0.002$

$-0.001$

0.001

0.002

$-0.001$

$0.012 \quad-0.022 \quad-0.026$

1.070

$0.999-1.009$

0.897

$[-2.00]$

[-1.36]

[0.10]

[0.99]

$-0.095$

[-0.08]

Beta: Governance

\begin{tabular}{lll}
{$[0.32]$} & {$[-0.57]$} & {$[-0.71$} \\
\hline 0.9015 & 0.8624 & 0.7572
\end{tabular}

0.044

[73.03]

[36.64]

0.869

0.967

0.093

Adjusted R ${ }^{2}$

re

Panel 3: US only markets universe

Panel 3A: CAPM

Alpha (\%)

\begin{tabular}{|c|c|c|c|c|c|c|c|c|c|c|c|}
\hline-0.001 & -0.001 & -0.002 & -0.001 & -0.003 & -0.004 & -0.003 & -0.003 & -0.003 & -0.002 & 0.001 & -0.002 \\
\hline$[-0.84]$ & {$[-0.88]$} & {$[-1.71]$} & {$[-0.68]$} & {$[-3.21]$} & {$[-4.57]$} & {$[-2.73]$} & {$[-2.59]$} & {$[-2.54]$} & {$[-1.76]$} & {$[1.69] *$} & {$[-1.41] \dagger$} \\
\hline 0.923 & 1.003 & 0.966 & 0.967 & 0.942 & 0.967 & 0.956 & 0.924 & 0.846 & 0.855 & 0.068 & 0.216 \\
\hline [37.05] & [45.95] & [34.52] & [30.8] & [29.55] & [37.21] & [24.33] & [29.70] & [24.20] & [27.05] & [2.01] & {$[1.87]$} \\
\hline 0.9101 & 0.9110 & 0.9169 & 0.9058 & 0.8976 & 0.9145 & 0.9080 & 0.9060 & 0.8948 & 0.8882 & 0.0355 & 0.0313 \\
\hline 0.002 & 0.002 & 0.001 & 0.001 & 0.001 & 0.001 & 0.001 & 0.001 & 0.002 & 0.004 & -0.002 & -0.008 \\
\hline [1.88] & [2.39] & [0.39] & [0.59] & {$[0.07]$} & [0.08] & {$[0.04]$} & [0.95] & [1.79] & [4.17] & {$[-1.58] \dagger$} & {$[-2.40] * *$} \\
\hline 0.952 & 1.013 & 1.007 & 0.988 & 0.933 & 0.976 & 0.946 & 0.931 & 0.854 & 0.870 & 0.083 & 0.323 \\
\hline [38.51] & [50.25] & [43.91] & [29.54] & [28.83] & [46.52] & [31.34] & [36.07] & [30.98] & [41.53] & {$[2.71]$} & [2.98] \\
\hline
\end{tabular}




\begin{tabular}{|c|c|c|c|c|c|c|c|c|c|c|c|c|}
\hline Beta: SMB & $\begin{array}{l}-0.232 \\
{[-5.08]}\end{array}$ & $\begin{array}{l}-0.207 \\
{[-4.30]}\end{array}$ & $\begin{array}{l}-0.228 \\
{[-5.38]}\end{array}$ & $\begin{array}{l}-0.119 \\
{[-2.01]}\end{array}$ & $\begin{array}{l}-0.151 \\
{[-2.84]}\end{array}$ & $\begin{array}{l}-0.250 \\
{[-6.45]}\end{array}$ & $\begin{array}{l}-0.162 \\
{[-4.36]}\end{array}$ & $\begin{array}{l}-0.247 \\
{[-5.10]}\end{array}$ & $\begin{array}{l}-0.256 \\
{[-5.93]}\end{array}$ & $\begin{array}{l}-0.342 \\
{[-8.75]}\end{array}$ & $\begin{array}{l}0.110 \\
{[2.09]^{*}}\end{array}$ & $\begin{array}{l}0.052 \\
{[0.20]}\end{array}$ \\
\hline \multirow[t]{2}{*}{ Beta: HML } & -0.053 & 0.069 & -0.144 & -0.074 & 0.170 & 0.108 & 0.184 & 0.118 & 0.121 & 0.131 & -0.184 & -0.830 \\
\hline & {$[-1.01]$} & [1.34] & {$[-3.18]$} & {$[-1.69]$} & [2.81] & [2.79] & [2.99] & {$[2.7]$} & {$[2.46]$} & {$[3.50]$} & {$[-2.99]$} & {$[-3.69]$} \\
\hline Adjusted $\mathrm{R}^{2}$ & 0.9246 & 0.9217 & 0.9334 & 0.9095 & 0.9105 & 0.9332 & 0.9230 & 0.9265 & 0.9209 & 0.9310 & 0.1294 & 0.1525 \\
\hline \multicolumn{13}{|l|}{ Panel 3C: Carhart 4F } \\
\hline \multirow[t]{2}{*}{ Alpha (\%) } & 0.003 & 0.003 & 0.001 & 0.001 & 0.001 & 0.001 & 0.001 & 0.001 & 0.002 & 0.004 & -0.001 & -0.010 \\
\hline & {$[2.72]$} & {$[3.05]$} & {$[0.79]$} & {$[0.39]$} & {$[0.71]$} & {$[0.02]$} & {$[0.24]$} & {$[1.23]$} & {$[2.30]$} & {$[4.30]$} & {$[-1.28] \dagger$} & {$[-2.86]^{* *}$} \\
\hline \multirow[t]{2}{*}{ Beta: Market (excess return) } & 0.999 & 1.048 & 1.032 & 0.977 & 0.979 & 0.973 & 0.962 & 0.956 & 0.885 & 0.890 & 0.109 & 0.230 \\
\hline & [36.60] & [46.02] & [51.29] & {$[27.50]$} & [36.11] & [39.64] & [33.52] & [41.18] & [34.08] & [38.68] & {$[2.94]$} & [2.32] \\
\hline \multirow[t]{2}{*}{ Beta: SMB } & -0.281 & -0.243 & -0.254 & -0.108 & -0.198 & -0.247 & -0.178 & -0.272 & -0.288 & -0.363 & 0.083 & 0.148 \\
\hline & {$[-6.18]$} & {$[-4.89]$} & {$[-6.15]$} & {$[-1.52]$} & {$[-3.55]$} & {$[-5.68]$} & {$[-4.80]$} & {$[-4.80]$} & {$[-6.49]$} & {$[-8.02]$} & {$[1.45]$} & {$[0.56]$} \\
\hline \multirow[t]{2}{*}{ Beta: HML } & -0.054 & 0.068 & -0.145 & -0.073 & 0.168 & 0.108 & 0.183 & 0.117 & 0.120 & 0.130 & -0.185 & -0.826 \\
\hline & {$[-1.13]$} & {$[1.38]$} & {$[-3.07]$} & {$[-1.75]$} & [2.93] & [2.79] & [3.12] & {$[2.79]$} & {$[2.68]$} & {$[3.42]$} & {$[-3.12]$} & {$[-3.84]$} \\
\hline \multirow[t]{2}{*}{ Beta: Momentum } & 0.086 & 0.063 & 0.046 & -0.020 & 0.084 & -0.006 & 0.028 & 0.046 & 0.056 & 0.038 & 0.047 & -0.169 \\
\hline & {$[2.97]$} & {$[2.22]$} & {$[2.63]$} & {$[-0.49]$} & {$[3.26]$} & {$[-0.20]$} & {$[1.17]$} & {$[1.46]$} & [2.91] & [1.39] & {$[1.75]$} & {$[-2.64]$} \\
\hline Adjusted $\mathrm{R}^{2}$ & 0.9339 & 0.9258 & 0.9356 & 0.9095 & 0.9188 & 0.9329 & 0.9236 & 0.9288 & 0.9253 & 0.9329 & 0.1491 & 0.1757 \\
\hline \multicolumn{13}{|l|}{ Panel 3D: Liquidity 2F (1y) } \\
\hline \multirow[t]{2}{*}{ Alpha $(\%)$} & -0.001 & -0.001 & -0.001 & 0.001 & -0.003 & -0.003 & -0.003 & -0.002 & -0.002 & -0.001 & 0.001 & 0.001 \\
\hline & {$[-1.41]$} & {$[-0.32]$} & {$[-0.18]$} & {$[1.82]$} & {$[-2.56]$} & {$[-3.59]$} & {$[-2.09]$} & {$[-1.78]$} & {$[-1.81]$} & {$[-0.88]$} & {$[1.40] \dagger$} & [1.13] \\
\hline \multirow[t]{2}{*}{ Beta: Market (excess return) } & 0.912 & 0.990 & 0.934 & 0.943 & 0.936 & 0.954 & 0.949 & 0.906 & 0.833 & 0.838 & 0.074 & 0.166 \\
\hline & [35.69] & [45.13] & [39.37] & [37.49] & [30.36] & [34.38] & [23.08] & [27.69] & [22.60] & [23.65] & {$[2.08]$} & {$[1.63]$} \\
\hline \multirow[t]{2}{*}{ Beta: Liquidity } & 0.078 & 0.090 & 0.214 & 0.164 & 0.041 & 0.088 & 0.046 & 0.118 & 0.091 & 0.118 & -0.040 & 0.338 \\
\hline & [1.98] & {$[2.00]$} & {$[6.14]$} & {$[3.60]$} & {$[0.65]$} & {$[2.35]$} & {$[0.89]$} & [3.49] & {$[2.12]$} & {$[2.72]$} & {$[-0.79]$} & {$[1.64]$} \\
\hline Adjusted $\mathrm{R}^{2}$ & 0.9121 & 0.9133 & 0.9334 & 0.9151 & 0.8977 & 0.9169 & 0.9083 & 0.9111 & 0.8982 & 0.8941 & 0.0358 & 0.0598 \\
\hline \multicolumn{13}{|c|}{ Panel 3E: Investor Protection 2F (1y) } \\
\hline \multirow[t]{2}{*}{ Alpha $(\%)$} & -0.001 & 0.001 & -0.001 & 0.001 & -0.002 & -0.004 & -0.003 & -0.003 & -0.002 & -0.002 & 0.001 & 0.001 \\
\hline & {$[-0.16]$} & {$[0.10]$} & {$[-1.03]$} & {$[0.17]$} & {$[-2.37]$} & {$[-3.98]$} & {$[-2.57]$} & {$[-2.35]$} & {$[-2.12]$} & {$[-1.34]$} & {$[1.99]^{*}$} & {$[1.03]$} \\
\hline \multirow[t]{2}{*}{ Beta: Market (excess return) } & 0.877 & 0.947 & 0.921 & 0.929 & 0.906 & 0.948 & 0.942 & 0.891 & 0.816 & 0.832 & 0.045 & 0.104 \\
\hline & [30.32] & [34.76] & [34.80] & [29.55] & {$[23.46]$} & [29.62] & [22.16] & [25.03] & [20.30] & [19.87] & {$[1.06]$} & {$[0.76]$} \\
\hline \multirow[t]{2}{*}{ Beta: Investor Protect } & 0.191 & 0.233 & 0.187 & 0.157 & 0.148 & 0.078 & 0.055 & 0.132 & 0.123 & 0.094 & 0.096 & 0.461 \\
\hline & {$[3.95]$} & [4.61] & {$[3.76]$} & {$[2.03]$} & {$[2.03]$} & {$[1.46]$} & {$[1.13]$} & [2.09] & {$[2.14]$} & {$[1.24]$} & {$[1.46]$} & {$[2.16]$} \\
\hline Adjusted $\mathrm{R}^{2}$ & 0.9181 & 0.9213 & 0.9239 & 0.9105 & 0.9019 & 0.9153 & 0.9082 & 0.9095 & 0.8984 & 0.8900 & 0.0481 & 0.0621 \\
\hline \multicolumn{13}{|l|}{ Panel 3F: Governance 2F(1y) } \\
\hline Alpha $(\%)$ & $\begin{array}{l}-0.002 \\
{[-0.37]}\end{array}$ & $\begin{array}{l}-0.001 \\
{[-1.05]}\end{array}$ & $\begin{array}{l}-0.002 \\
{[-1.00]}\end{array}$ & $\begin{array}{l}-0.001 \\
{[-0.76]}\end{array}$ & $\begin{array}{l}-0.003 \\
{[-2.04]}\end{array}$ & $\begin{array}{l}-0.004 \\
{[-3.32]}\end{array}$ & $\begin{array}{l}-0.003 \\
{[-1.53]}\end{array}$ & $\begin{array}{l}-0.003 \\
{[-1.40]}\end{array}$ & $\begin{array}{l}-0.003 \\
{[-1.17]}\end{array}$ & $\begin{array}{l}-0.002 \\
{[-0.37]}\end{array}$ & ---- & ---- \\
\hline
\end{tabular}




\begin{tabular}{|c|c|c|c|c|c|c|c|c|c|c|c|c|}
\hline Beta: Market (excess return) & $\begin{array}{l}0.892 \\
{[42.90]}\end{array}$ & $\begin{array}{l}0.991 \\
{[47.73]}\end{array}$ & $\begin{array}{l}0.955 \\
{[36.53]}\end{array}$ & $\begin{array}{l}0.962 \\
{[32.30]}\end{array}$ & $\begin{array}{l}0.947 \\
{[30.14]}\end{array}$ & $\begin{array}{l}0.983 \\
{[45.39]}\end{array}$ & $\begin{array}{l}0.963 \\
{[26.20]}\end{array}$ & $\begin{array}{l}0.933 \\
{[30.62]}\end{array}$ & $\begin{array}{l}0.862 \\
{[27.85]}\end{array}$ & $\begin{array}{l}0.892 \\
{[42.9]}\end{array}$ & ---- & ---- \\
\hline Beta: Governance & $\begin{array}{l}0.465 \\
{[6.58]}\end{array}$ & $\begin{array}{l}0.178 \\
{[1.49]}\end{array}$ & $\begin{array}{l}0.173 \\
{[2.00]}\end{array}$ & $\begin{array}{l}0.076 \\
{[0.81]}\end{array}$ & $\begin{array}{l}-0.077 \\
{[-0.92]}\end{array}$ & $\begin{array}{l}-0.234 \\
{[-3.18]}\end{array}$ & $\begin{array}{l}-0.113 \\
{[-1.30]}\end{array}$ & $\begin{array}{l}-0.141 \\
{[-2.05]}\end{array}$ & $\begin{array}{l}-0.232 \\
{[-2.89]}\end{array}$ & $\begin{array}{l}-0.535 \\
{[-7.56]}\end{array}$ & ---- & -- -- \\
\hline Adjusted $\mathrm{R}^{2}$ & 0.9355 & 0.9138 & 0.9198 & 0.9060 & 0.8978 & 0.9201 & 0.9090 & 0.9079 & 0.9019 & 0.9266 & ---- & ---- \\
\hline \multicolumn{13}{|c|}{ Panel 3G: Governance 2F(1y) using Investor Protection deciles } \\
\hline Alpha $(\%)$ & $\begin{array}{l}-0.001 \\
{[-1.14]}\end{array}$ & $\begin{array}{l}0.001 \\
{[0.07]}\end{array}$ & $\begin{array}{l}-0.001 \\
{[-1.56]}\end{array}$ & $\begin{array}{l}-0.001 \\
{[-1.97]}\end{array}$ & $\begin{array}{l}-0.002 \\
{[-3.19]}\end{array}$ & $\begin{array}{l}-0.001 \\
{[-1.27]}\end{array}$ & $\begin{array}{l}-0.001 \\
{[-1.90]}\end{array}$ & $\begin{array}{l}0.001 \\
{[0.08]}\end{array}$ & $\begin{array}{l}0.002 \\
{[1.70]}\end{array}$ & $\begin{array}{l}0.005 \\
{[2.56]}\end{array}$ & $\begin{array}{l}-0.006 \\
{[-2.33]}\end{array}$ & $\begin{array}{l}0.010 \\
{[1.88]}\end{array}$ \\
\hline Beta: Market (excess return) & $\begin{array}{l}1.106 \\
{[51.34]}\end{array}$ & $\begin{array}{l}1.078 \\
{[27.71]}\end{array}$ & $\begin{array}{l}1.044 \\
{[59.86]}\end{array}$ & $\begin{array}{l}1.061 \\
{[84.71]}\end{array}$ & $\begin{array}{l}1.012 \\
{[56.63]}\end{array}$ & $\begin{array}{l}0.975 \\
{[33.76]}\end{array}$ & $\begin{array}{l}1.007 \\
{[64.73]}\end{array}$ & $\begin{array}{l}0.944 \\
{[61.03]}\end{array}$ & $\begin{array}{l}0.919 \\
{[33.33]}\end{array}$ & $\begin{array}{l}0.875 \\
{[26.06]}\end{array}$ & $\begin{array}{l}0.231 \\
{[4.95]}\end{array}$ & $\begin{array}{l}-0.309 \\
{[-2.63]}\end{array}$ \\
\hline Beta: Governance & $\begin{array}{l}0.043 \\
{[0.69]}\end{array}$ & $\begin{array}{l}0.033 \\
{[0.59]}\end{array}$ & $\begin{array}{l}0.006 \\
{[0.14]}\end{array}$ & $\begin{array}{l}0.016 \\
{[0.38]}\end{array}$ & $\begin{array}{l}0.011 \\
{[0.27]}\end{array}$ & $\begin{array}{l}-0.020 \\
{[-0.36]}\end{array}$ & $\begin{array}{l}0.083 \\
{[1.90]}\end{array}$ & $\begin{array}{l}-0.101 \\
{[-2.08]}\end{array}$ & $\begin{array}{l}0.049 \\
{[0.62]}\end{array}$ & $\begin{array}{l}-0.144 \\
{[-1.69]}\end{array}$ & $\begin{array}{l}0.187 \\
{[1.53]}\end{array}$ & $\begin{array}{l}0.522 \\
{[1.89]}\end{array}$ \\
\hline Adjusted $\mathrm{R}^{2}$ & 0.9590 & 0.8387 & 0.9694 & 0.9747 & 0.9634 & 0.9515 & 0.9710 & 0.9581 & 0.8997 & 0.8572 & 0.2225 & 0.0784 \\
\hline
\end{tabular}


Table 7 Time varying parameter model tests of CAPM-type and multifactor models using monthly excess returns for decile size, book-tomarket value, investor protection and governance-sorted portfolios with annual rebalancing for the period January 2001 - September 2017

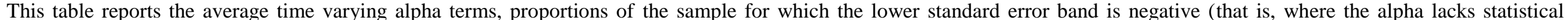

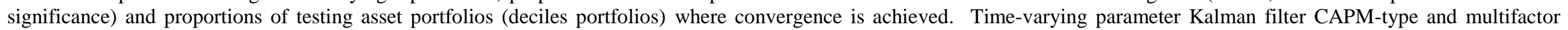

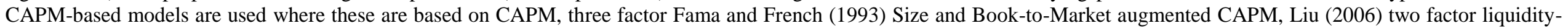

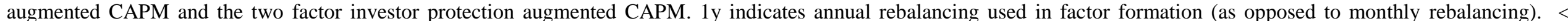
denotes the largest negative value of each of the three information criterion (that is the model of choice)

\begin{tabular}{|c|c|c|c|c|c|c|c|c|c|c|c|c|}
\hline \multirow[b]{3}{*}{ Panel 1: OECD overall } & \multicolumn{2}{|c|}{ Time series } & \multicolumn{3}{|c|}{ Information criterion } & \multirow{2}{*}{$\begin{array}{l}\% \\
\text { Converge }\end{array}$} & \multicolumn{2}{|c|}{ Time series } & \multicolumn{3}{|c|}{ Information criterion } & \multirow{2}{*}{$\begin{array}{l}\% \\
\text { Converge }\end{array}$} \\
\hline & $\begin{array}{l}\text { Mean } \\
\text { alpha }\end{array}$ & $\begin{array}{l}\text { \% SE } \\
\text { (alpha) } \\
\text { negative }\end{array}$ & SBC & HQC & AIC & & $\begin{array}{l}\text { Mean } \\
\text { alpha }\end{array}$ & $\begin{array}{l}\text { \% SE } \\
\text { (alpha) } \\
\text { negative }\end{array}$ & SBC & HQC & AIC & \\
\hline & \multicolumn{6}{|c|}{ Size decile portfolios } & \multicolumn{5}{|c|}{ Book-to-Market decile portfolios } & \\
\hline CAPM & -0.00077 & $58.35 \%$ & -5.44 & -5.41 & -5.43 & $90.00 \%$ & -0.00064 & $68.44 \%$ & -5.59 & -5.56 & -5.58 & $100.00 \%$ \\
\hline $\mathrm{FF} 3 \mathrm{~F}$ & -0.00281 & $45.15 \%$ & -5.56 & -5.49 & -5.53 & $40.00 \%$ & -0.00050 & $73.23 \%$ & -5.72 & -5.65 & -5.69 & $50.00 \%$ \\
\hline Carhart 4F & -0.00145 & $80.32 \%$ & -5.35 & -5.26 & -5.31 & $50.00 \%$ & 0.00061 & $77.35 \%$ & -5.72 & -5.65 & -5.69 & $50.00 \%$ \\
\hline Liquidity $2 \mathrm{~F}(1 \mathrm{yr})$ & -0.00030 & $70.54 \%$ & -5.51 & -5.46 & -5.49 & $80.00 \%$ & -0.00009 & $73.33 \%$ & -5.71 & -5.67 & -5.69 & $100.00 \%$ \\
\hline Investor Protect $2 \mathrm{~F}$ (1yr) & -0.00079 & $67.20 \%$ & -5.46 & -5.41 & -5.44 & $70.00 \%$ & -0.00067 & $73.10 \%$ & -5.56 & -5.51 & -5.54 & $100.00 \%$ \\
\hline \multirow[t]{2}{*}{ Governance $2 \mathrm{~F}(1 \mathrm{yr})$} & -0.00079 & $66.35 \%$ & $-5.62<$ & $-5.57<$ & $-5.60<$ & $50.00 \%$ & -0.00050 & $72.29 \%$ & $-5.81<$ & $-5.76<$ & $-5.79<$ & $80.00 \%$ \\
\hline & \multicolumn{6}{|c|}{ Investor Protection-1y decile portfolios } & \multicolumn{5}{|c|}{ Governance-1y decile portfolios } & \\
\hline CAPM & -0.00008 & $51.05 \%$ & -5.15 & -5.12 & -5.14 & $80.00 \%$ & -0.00281 & $72.18 \%$ & -4.73 & -4.70 & -4.72 & $100.00 \%$ \\
\hline FF3F & 0.00009 & $69.31 \%$ & -5.18 & -5.11 & -5.15 & $30.00 \%$ & -0.00207 & $78.48 \%$ & -4.52 & -4.45 & -4.49 & $30.00 \%$ \\
\hline Carhart 4F & -0.00035 & $76.19 \%$ & -5.19 & -5.11 & -5.16 & $30.00 \%$ & -0.00315 & $85.19 \%$ & -3.85 & -3.76 & -3.81 & $10.00 \%$ \\
\hline Liquidity $2 \mathrm{~F}(1 \mathrm{yr})$ & -0.00017 & $67.45 \%$ & -5.13 & -5.09 & -5.12 & $100.00 \%$ & -0.00041 & $70.38 \%$ & -4.80 & -4.76 & -4.78 & $100.00 \%$ \\
\hline Investor Protect $2 \mathrm{~F}(1 \mathrm{yr})$ & -0.00013 & $63.89 \%$ & $-5.30<$ & $-5.25<$ & $-5.28<$ & $40.00 \%$ & -0.00220 & $75.00 \%$ & -4.81 & -4.76 & -4.79 & $80.00 \%$ \\
\hline Governance $2 \mathrm{~F}(1 \mathrm{yr})$ & -0.00037 & $68.56 \%$ & -5.18 & -5.13 & -5.16 & $70.00 \%$ & -0.00231 & $76.13 \%$ & $-5.03<$ & $-4.98<$ & $-5.01<$ & $90.00 \%$ \\
\hline Panel 2: OECD exclude US & \multicolumn{6}{|c|}{ Size decile portfolios } & \multicolumn{5}{|c|}{ Book-to-Market decile portfolios } & \\
\hline CAPM & -0.00077 & $64.47 \%$ & -5.11 & -5.08 & -5.10 & $100.00 \%$ & -0.00056 & $72.67 \%$ & -5.40 & -5.36 & -5.38 & $100.00 \%$ \\
\hline FF3F & -0.00236 & $79.19 \%$ & -5.16 & -5.10 & -5.14 & $60.00 \%$ & -0.00174 & $85.45 \%$ & -5.39 & -5.32 & -5.36 & $20.00 \%$ \\
\hline Carhart 4F & -0.00235 & $69.14 \%$ & -5.22 & -5.13 & -5.18 & $50.00 \%$ & -0.00088 & $69.66 \%$ & $-5.69<$ & $-5.61<$ & $-5.66<$ & $50.00 \%$ \\
\hline Liquidity $2 \mathrm{~F}(1 \mathrm{yr})$ & -0.00049 & $74.73 \%$ & -5.05 & -5.01 & -5.03 & $70.00 \%$ & -0.00021 & $72.96 \%$ & -5.55 & -5.50 & -5.53 & $100.00 \%$ \\
\hline Investor Protect $2 \mathrm{~F}$ (1yr) & -0.00102 & $67.28 \%$ & -5.33 & -5.28 & -5.31 & $60.00 \%$ & -0.00024 & $72.66 \%$ & -5.37 & -5.32 & -5.35 & $60.00 \%$ \\
\hline \multirow[t]{2}{*}{ Governance $2 \mathrm{~F}(1 \mathrm{yr})$} & -0.00435 & $76.81 \%$ & $-5.38<$ & $-5.33<$ & $-5.36<$ & $60.00 \%$ & -0.00036 & $78.31 \%$ & -5.40 & -5.35 & -5.38 & $70.00 \%$ \\
\hline & \multicolumn{6}{|c|}{ Investor Protection-1y decile portfolios } & \multicolumn{5}{|c|}{ Governance-1y decile portfolios } & \\
\hline CAPM & -0.00018 & $68.07 \%$ & -4.79 & -4.76 & -4.78 & $90.00 \%$ & -0.00301 & $71.12 \%$ & -4.30 & -4.27 & -4.29 & $100.00 \%$ \\
\hline FF3F & -0.00044 & $62.35 \%$ & -4.88 & -4.82 & -4.86 & $50.00 \%$ & -0.00120 & $73.17 \%$ & -4.24 & -4.17 & -4.21 & $70.00 \%$ \\
\hline Carhart 4F & -0.00103 & $81.06 \%$ & $-5.14<$ & -5.06 & -5.10 & $50.00 \%$ & -0.00009 & $58.84 \%$ & -4.16 & -4.08 & -4.13 & $40.00 \%$ \\
\hline Liquidity $2 \mathrm{~F}$ (1yr) & -0.00007 & $67.57 \%$ & -5.12 & $-5.07<$ & $-5.10<$ & $100.00 \%$ & 0.00022 & $64.23 \%$ & -4.55 & -4.50 & -4.53 & $90.00 \%$ \\
\hline
\end{tabular}




\begin{tabular}{|c|c|c|c|c|c|c|c|c|c|c|c|c|}
\hline Investor Protect $2 \mathrm{~F}(1 \mathrm{yr})$ & -0.00039 & $58.94 \%$ & -4.91 & -4.86 & -4.89 & $40.00 \%$ & -0.00241 & $73.47 \%$ & -4.31 & -4.26 & -4.29 & $70.00 \%$ \\
\hline Governance $2 \mathrm{~F}$ (1yr) & -0.00034 & $71.75 \%$ & -4.72 & -4.68 & -4.70 & $50.00 \%$ & -0.00288 & $81.07 \%$ & $-4.59<$ & $-4.54<$ & $-4.57<$ & $90.00 \%$ \\
\hline Panel 3: US only & \multicolumn{6}{|c|}{ Size decile portfolios } & \multicolumn{6}{|c|}{ Book-to-Market decile portfolios } \\
\hline CAPM & -0.00123 & $66.73 \%$ & -4.87 & -4.84 & -4.86 & $100.00 \%$ & -0.00039 & $66.81 \%$ & -5.04 & -5.00 & -5.02 & $100.00 \%$ \\
\hline FF3F & 0.00006 & $72.77 \%$ & -4.81 & -4.75 & -4.79 & $70.00 \%$ & 0.00018 & $76.19 \%$ & -5.05 & -4.98 & -5.02 & $80.00 \%$ \\
\hline Carhart 4F & 0.00028 & $74.71 \%$ & -4.81 & -4.72 & -4.77 & $50.00 \%$ & 0.00029 & $81.14 \%$ & $-5.10<$ & $-5.02<$ & $-5.07<$ & $60.00 \%$ \\
\hline Liquidity $2 \mathrm{~F}$ (1yr) & -0.00050 & $72.31 \%$ & -4.10 & -4.06 & -4.09 & $60.00 \%$ & -0.00034 & $74.10 \%$ & -4.32 & -4.28 & -4.31 & $80.00 \%$ \\
\hline Investor Protect $2 \mathrm{~F}$ (1yr) & -0.00182 & $75.32 \%$ & -4.89 & -4.84 & -4.87 & $60.00 \%$ & 0.00007 & $68.33 \%$ & -4.79 & -4.74 & -4.77 & $70.00 \%$ \\
\hline \multirow[t]{2}{*}{ Governance $2 \mathrm{~F}(1 \mathrm{yr})$} & -0.00131 & $72.56 \%$ & $-4.96<$ & $-4.91<$ & $-4.94<$ & $90.00 \%$ & -0.00008 & $71.60 \%$ & -4.97 & -4.92 & -4.95 & $90.00 \%$ \\
\hline & \multicolumn{6}{|c|}{ Investor Protection-1y decile portfolios } & \multicolumn{6}{|c|}{ Governance-1y decile portfolios } \\
\hline CAPM & -0.00123 & $66.73 \%$ & -4.87 & -4.84 & -4.86 & $90.00 \%$ & -0.00162 & $67.55 \%$ & -4.65 & -4.62 & -4.64 & $100.00 \%$ \\
\hline FF3F & 0.00006 & $72.77 \%$ & -4.81 & -4.75 & -4.79 & $70.00 \%$ & 0.00133 & $76.82 \%$ & -4.75 & -4.68 & -4.72 & $90.00 \%$ \\
\hline Carhart 4F & 0.00028 & $74.71 \%$ & -4.81 & -4.72 & -4.77 & $50.00 \%$ & 0.00139 & $77.34 \%$ & -4.75 & -4.67 & -4.71 & $40.00 \%$ \\
\hline Liquidity $2 \mathrm{~F}$ (1yr) & -0.00050 & $72.31 \%$ & -4.10 & -4.06 & -4.09 & $60.00 \%$ & -0.00029 & $76.05 \%$ & -4.13 & -4.09 & -4.12 & $80.00 \%$ \\
\hline Investor Protect $2 \mathrm{~F}$ (1yr) & -0.00182 & $75.32 \%$ & -4.89 & -4.84 & -4.87 & $60.00 \%$ & -0.00011 & $74.61 \%$ & -4.68 & -4.63 & -4.66 & $80.00 \%$ \\
\hline Governance $2 \mathrm{~F}$ (1yr) & -0.00131 & $72.56 \%$ & $-4.96<$ & $-4.91<$ & $-4.94<$ & $90.00 \%$ & -0.00170 & $78.18 \%$ & $-4.85<$ & $-4.80<$ & $-4.83<$ & $90.00 \%$ \\
\hline
\end{tabular}




\section{Figure 1}

Global equity market firm sample by country and region, January 2000 to September 2017

The figure shows the distribution of sample stocks by country or region, with the sample size and percentage of the total for each. The sample selection criteria are described in the data section.

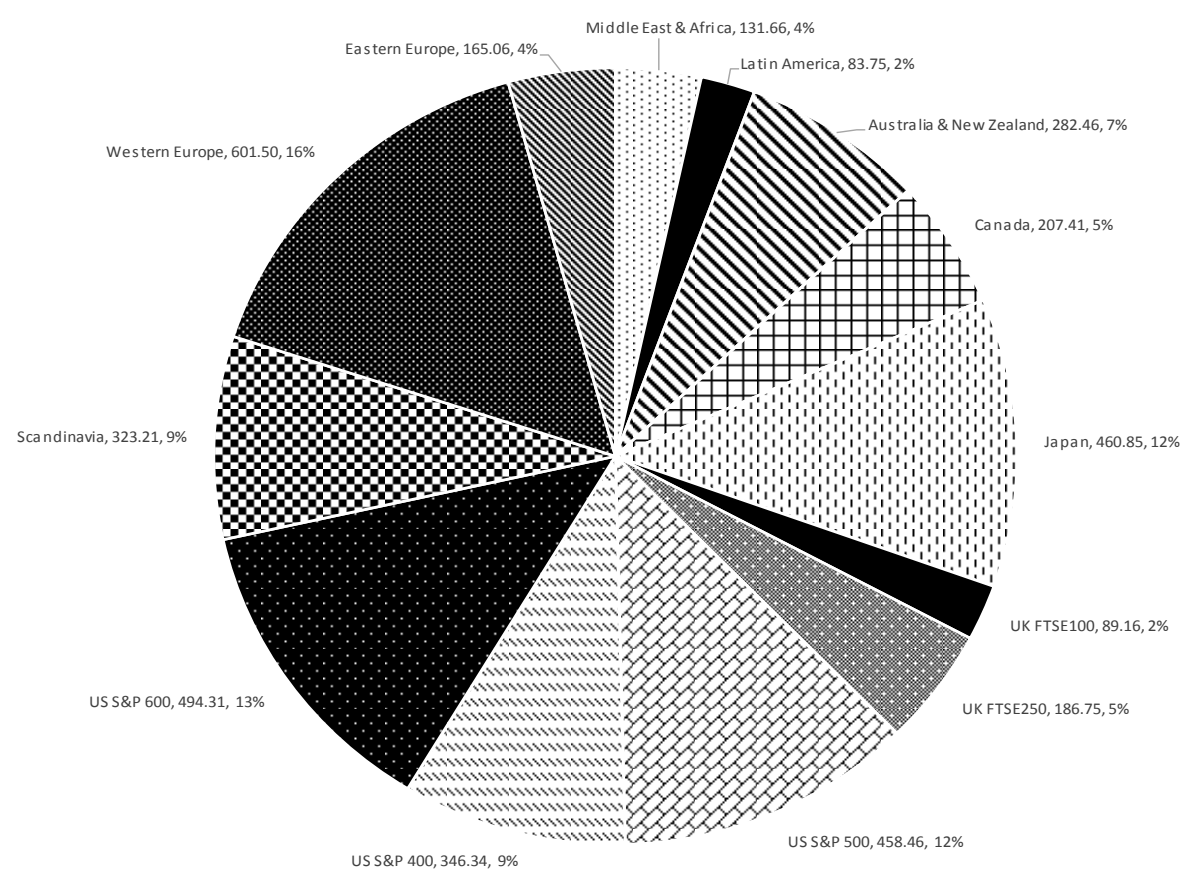

\section{Figure 2}

Global equity market firm sample by year, January 2000 to September 2017

The figure shows the distribution of sample stocks by region and month. The sample selection criteria are described in the data section.

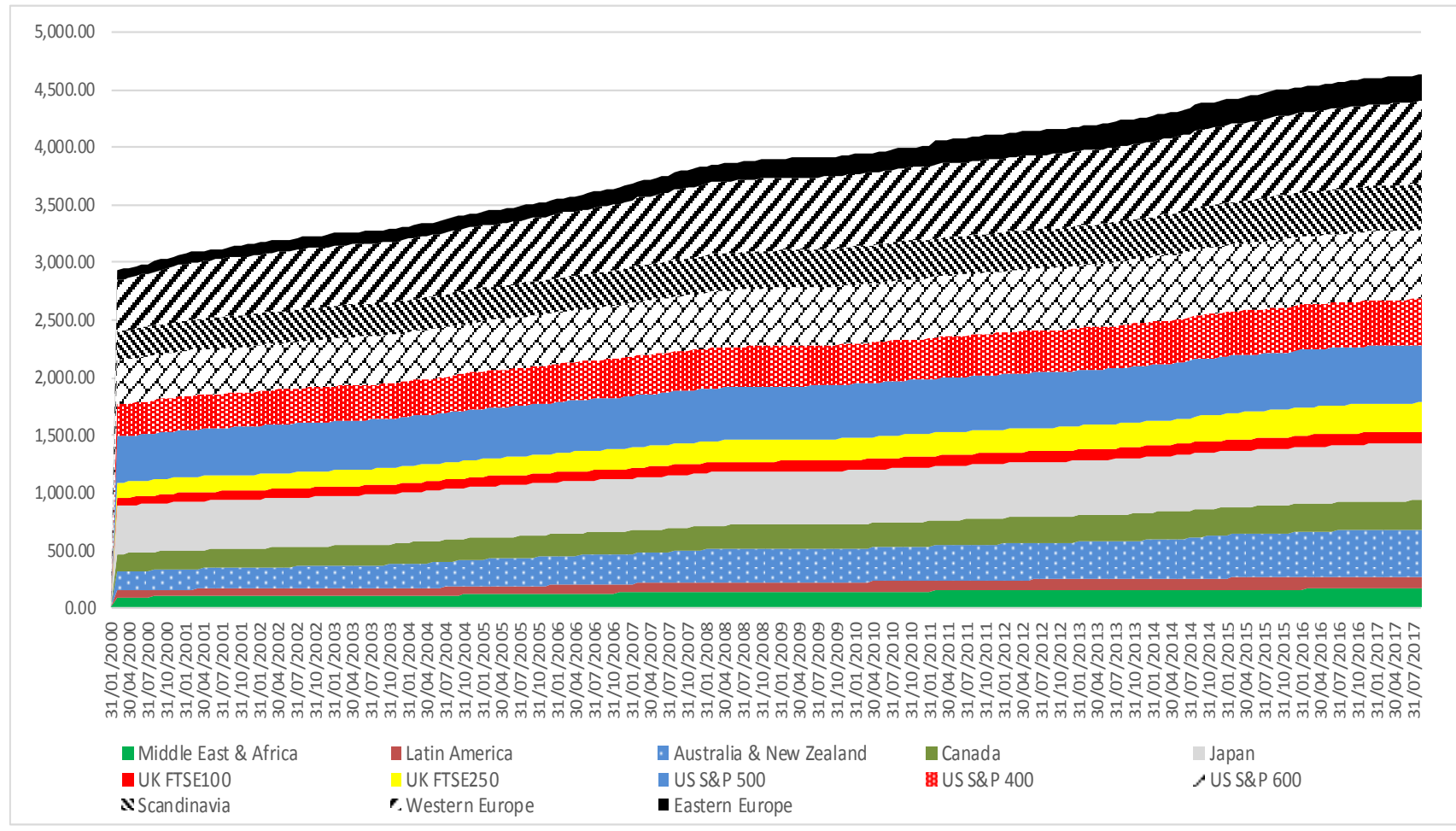




\section{Figure 3}

ASSET4 equity market firm sample by year, January 2002 to September 2017

The figure shows the distribution of sample stocks by region and month. The sample selection criteria are described in the data section.

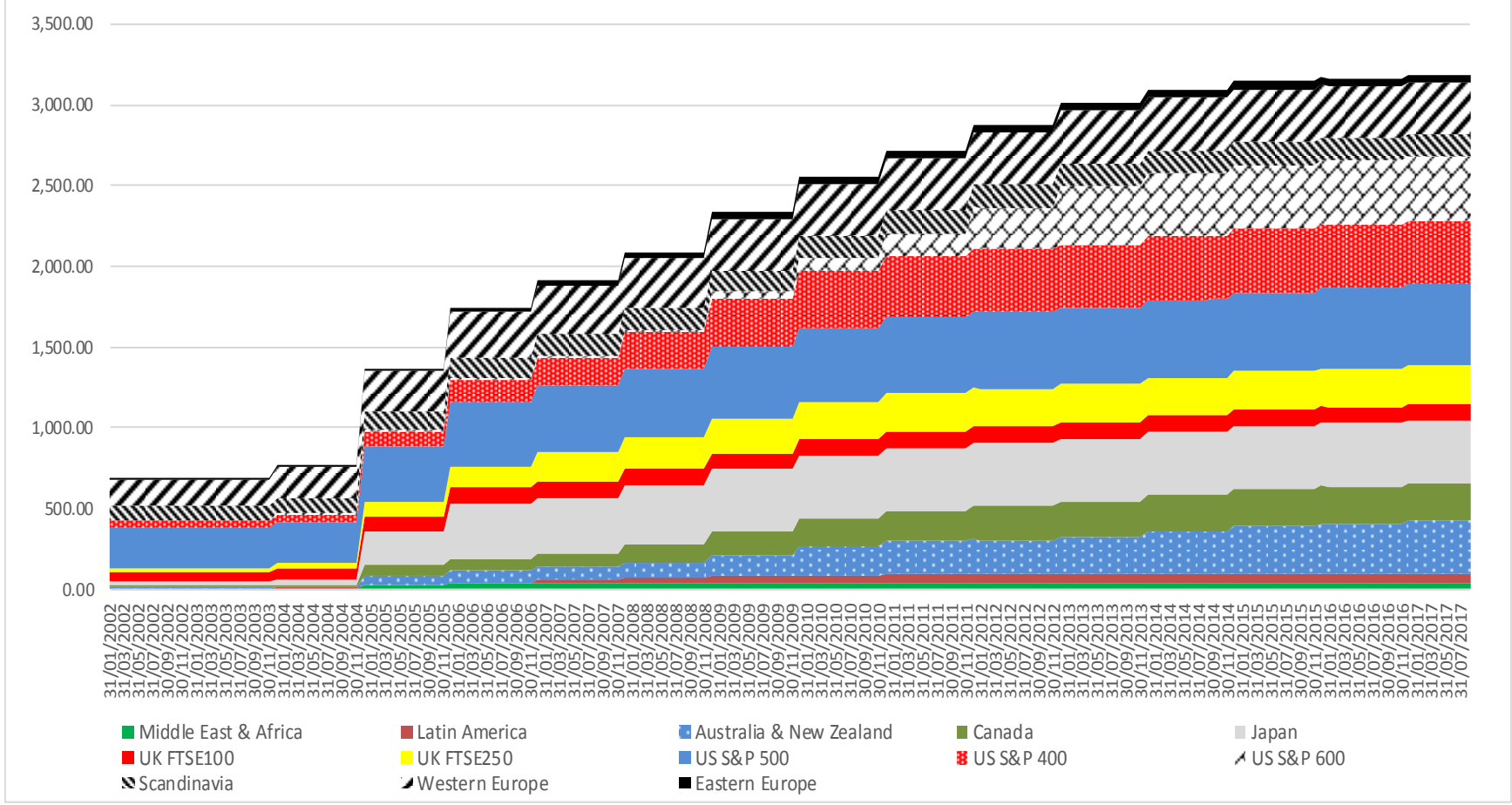


Appendix A. Table 1A.

Datastream variable definitions

All data are from Datastream and Worldscope (accessed through Datastream)

\begin{tabular}{|c|c|c|c|}
\hline Coverage & Index & Description & $\begin{array}{l}\text { Datastream } \\
\text { Mnemonic }\end{array}$ \\
\hline Australia & S\&P/ASX 300 [300] & Source: S\&P/ASX & LASX300I \\
\hline Austria & ATX Index [20] & Source: Wiener Bourse & LATXINDX \\
\hline Belgium & BEL $20[20]$ & Source: Belgium stock exchange & LBGBEL20 \\
\hline Canada & S\&P/TSX Composite [248] & Source: S\&P/TSX & LTTOCOMP \\
\hline Chile & IPSA [40] & Source: Santiago stock exchange & LIPSASEL \\
\hline Czech Republic & Prague SE PX Global [24] & Source: Prague stock exchange & LCZPXGLB \\
\hline Denmark & OMX Copenhagen [135] & Source: Nasdaq OMX & LCOSEASH \\
\hline Estonia & TRX Estonia Al-Share [32] & Source: Thomson Datastream & LTR0EOXXD \\
\hline Finland & OMX Helsinki [135] & Source: Nasdaq OMX & LHEXINDX \\
\hline France & France CAC Large 60 [60] & Source: Euronext Paris & LFRCLR60 \\
\hline Germany & DJ DAX $100[100]$ & Source: Deutsche Börse & LDAX100I0700 \\
\hline Greece & Athens Composite [60] & Source: Athens stock exchange & LGRAGENL \\
\hline Hungary & Budapest (BUX) [14] & Source: Budapest stock exchange & LBUXINDX \\
\hline Iceland & OMX Iceland All Share [16] & Source: Nasdaq OMX & LICEXALL \\
\hline Ireland & ISEQ Overall [47] & Source: Irish stock exchange & LISEQUIT \\
\hline Israel & Dow Jones Tel Aviv 100 [101] & Source: Israel stock exchange & LISTA100 \\
\hline Italy & All Stars [74] & Source: Milan Bourse & LMIBASTR \\
\hline Japan & S\&P TOPIX 500 [498] & Source: Japan stock exchange & LTSET500 \\
\hline Latvia & Latvia TRX All-Sector [67] & Source: Thomson Datastream & LTROLVXXD \\
\hline Luxembourg & Luxembourg SE LUXX [9] & Source: Luxembourg stock exchange & LLXLUXXI \\
\hline Mexico & Indice Compuesto del Mercado Acciones [60] & Source: Mexican stock exchange & LMXIRTCM \\
\hline Netherlands & All Share General [140] & Source: CBS & LCBSKGEN \\
\hline New Zealand & S\&P/NZX All Index [116] & Source: New Zealand stock exchange & LNZSEALL \\
\hline Norway & Oslo OBX [25] & Source: Oslo Bors & LOSLOOBX \\
\hline Poland & Warsaw General 20 [20] & Source: Warsaw stock exchange & LPOLWG20 \\
\hline Portugal & PSI All-Share [47] & Source: Euronext Lisbon & LPOPSIGN \\
\hline Slovakia & DS Market Constituents SSX [50] & Source: Thomson Datastream & LTOTSX \\
\hline Slovenia & Top stocks index [7] & Source: Ljubljana stock exchange & LSLOETOP \\
\hline South Korea & KOSPI $100[100]$ & Source: Korea stock exchange & LKOR100I \\
\hline Spain & Madrid SE General [108] & Source: Bolsas y Mercados Españoles & LMADRIDI \\
\hline Sweden & OMX Stockholm Benchmark [89] & Source: Nasdaq OMX & LSWEBENC \\
\hline Switzerland & UBS100 [100] & Source: SWX Swiss stock exchange & LSBC100I \\
\hline Turkey & BIST National 30 [30] & Source: Istanbul stock exchange & LTKNAT30 \\
\hline UK & Top 350 stocks & & \\
\hline UK & FTSE $100[101]$ & Source: FTSE & LFTSE100 \\
\hline UK & FTSE 250 [251] & Source: FTSE & LFTSE250 \\
\hline US & S\&P 1,500 constituents & & \\
\hline US S\&P 500 & S\&P 500 [Large cap stocks] [500] & Source: S\&P & LS\&PCOMP \\
\hline US S\&P 400 & S\&P 400 [Mid cap stocks] [400] & Source: S\&P & LS\&PMIDC \\
\hline US S\&P 600 & S\&P 600 [Small cap stocks] [600] & Source: S\&P & LS\&P600I \\
\hline
\end{tabular}




\section{Appendix B Table 1B.}

\section{Datastream variable and Worldwide governance indicator definitions}

All data are from Datastream and Worldscope (accessed through Datastream) with the exception of the six World Bank Governance indices, which are from http://info.worldbank.org/governance/wgi/index.aspx\#home

Variable

ASSET4-ESG Governance elements

Minority rights

Board diversity policy

Adequate experience of board policy

Board independence policy

Board size policy

CEO board member

Chairman is ex-CEO

Nomination committee

Succession plan for executives

Corporate governance committee

External consultants

Golden parachute

Limitation of director liability

Limitations on removal of directors

Limited shareholder rights to call meetings

Majority requirements for election of directors

Poison pill

\section{Voting}

Equal voting right policy

Shareholder engagement policy

Pre-emptive rights

Public availability corporate statutes

Advance notice for shareholder

proposals

Confidential voting policy

Different share classes different rights

Elimination of cumulative voting rights

Expanded constituency provision
Definition

Datastream

Mnemonic

Does the company have a policy regarding the diversity of its

CGBSDP0013

board? [Y/N]

Does the company have a policy regarding the adequate experience

on its board? [Y/N]

Does the company have a policy regarding the independence of its board? [Y/N]

Does the company have a policy regarding the size of its board? [Y/N]

The CEO is a board member. [Y/N]

Has the chairman previously held the CEO position in the company? [Y/N]

Does the company have a nomination committee? [Y/N]

Does the company have a succession plan for executive management in the event of unforeseen circumstances? [Y/N]

Does the company have a corporate governance committee? [Y/N]

Does the board or board committees have the authority to hire

external advisers or consultants without management's approval?

$[\mathrm{Y} / \mathrm{N}]$

Does the company have a golden parachute or other restrictive

clauses related to changes of control (compensation plan for accelerated pay-out)? [Y/N]

Does the company have a limitation of director liability? [Y/N]

Are there limitations on the shareholders' right to remove board members (i.e., only for cause, supermajority vote required, etc.)? [Y/N]

Has the company limited the rights of shareholders to call special meetings? [Y/N]

Are the company's board members elected with a majority vote?

$[\mathrm{Y} / \mathrm{N}]$

Does the company have a poison pill (shareholder rights plan, macaroni defence, etc.)? [Y/N]

Does the company have a policy to apply the one-share, one-vote principle? [Y/N]

Does the company have a policy to facilitate shareholder

engagement, resolutions or proposals? [Y/N]

Does the company grant pre-emptive rights to existing shareholders?

Are the company's articles of association, statutes or bylaws

publicly available? [Y/N]

Does the company have deadlines relating to shareholder proposals? [Y/N]

Does the company have a confidential voting policy (i.e., management cannot view the results of shareholder votes)? [Y/N]

Does the company have different class stocks with different voting rights? [Y/N]

Has the company reduced or eliminated cumulative voting in regard to the election of board members? [Y/N]

Does the company have expanded-constituency provisions in
CGBSDP0015

CGBSDP0012

CGBSDP0011

CGBSDP061

CGBSDP040

CGBSDP005

CGBFDP030

CGBFDP005

CGBFDP031

CGSRDP055

CGSRDP063

CGSRDP071

CGSRDP058

CGSRDP033

CGSRDP050

CGSRDP0011

CGSRDP0013

CGSRDP060

CGSRDP044

CGSRDP072

CGSRDP062

CGSRDP022

CGSRDP059 CGSRDP075 
Fair price provision

Min. number of shares to vote

Voting cap

Significant company transactions (M\&A) shareholder's approval

Supermajority vote requirements

Written consent requirements

Integrated strategy in MD\&A

\section{Delay}

Classified board structure

Staggered board structure

Company cross shareholding

Golden share

Blank check

State owned enterprise

\section{Director Incentives}

Shareholder's approval of stock based compensation Plan

CEO compensation link to shareholder return

Compensation committee

Compensation improvement tools

Executive retention compensation policy

Performance oriented compensation policy

Shareholders vote on executive pay

\section{Datastream items}

Free Float Number of Shares place? [Y/N]

Is the company subject to fair price provision, either under

CGSRDP070

applicable law or as stated in the company documents (charter or bylaws)? [Y/N]

Has the company set requirements for a minimum number of shares to vote? [Y/N]

Does the company have shares with a voting cap (ceilings) clause, ownership ceilings or control share acquisition provision? [Y/N]

Limitations to the shareholders right to approve significant

company transitions such as M\&As (no rights to vote or supermajority required)? [Y/N]

Does the company have a supermajority vote requirement or qualified majority (for amendments of charters and bylaws or lockin provisions)? [Y/N]

Does the company permit actions to be taken without meeting by written consent? [Y/N]

Does the company explicitly integrate financial and extra-financial factors in its management discussion and analysis (MD\&A) section in the annual report? [Y/N]

Does the company have a classified board structure? [Y/N]

Does the company have a staggered board structure? [Y/N]

Does the company have significant cross shareholding that can prevent takeovers? [Y/N]

Does the biggest owner (by voting power) hold the veto power or own golden shares? [Y/N]

Does the company have unlimited authorized capital or a blank check?

Is the company a State Owned Enterprise (SOE)? [Y/N]

CGSRDP028

CGSRDP026

CGSRDP069

CGSRDP054

CGSRDP074

CGVSDP018

CGSRDP052

CGSRDP053

CGSRDP061

CGSRDP048

CGSRDP051

CGSRDP049

Does the company require that shareholder approval is obtained prior to the adoption of any stock based compensation plans? [Y/N] Is the CEO's compensation linked to total shareholder return (TSR)? [Y/N]

Does the company have a compensation committee? [Y/N]

Does the company have the necessary internal improvement and information tools for the board members to develop appropriate compensation/remuneration to attract and retain key executives? [Y/N]

Does the company have a compensation policy to attract and retain executives? [Y/N]

Does the company have a performance oriented compensation policy? [Y/N]

Do the company's shareholders have the right to vote on executive compensation? [Y/N]

CGCPDP056

CGCPDP041

CGCPDP005

CGCPDP011

CGCPDP0014

CGCPDP0012

CGSRDP038

The percentage of total shares in issue available to ordinary investors (NOSHFF). That means total number of shares (NOSH) less the strategic holdings (NOSHST). In general, only holdings of $5 \%$ or more are counted as strategic.

Strategic ownership data is collected by the Thomson Reuters Ownership team, the data is derived from 11 primary sources, including SEC filings (such as schedule 13D and form 13FD) and the UK Register. Also annual, interim reports, stock exchanges, 
official regulatory bodies, third party vendors, company websites, approved news sources and direct contact with company investor relations departments

Ownership updates were obtained at end of month prior to August 2009 while after this date values are updated on the 10th and 30th of each month

Strategic holdings are defined as the sum of the following categories of shareholding:

(1) Government: State (government) or state (government) institution (NOSHGV)

(2) Cross Holdings: Holdings by one company in another (NOSHCO)

(3) Pension Fund: Pension funds or Endowment funds (NOSHPF)

(4) Investment Co.: Investment banks or institutions seeking a long term return. Note that holdings by Hedge Funds are not included (NOSHIC)

(5) Employees: Employees, or by those with a substantial position in a company that provides significant voting power at an annual general meeting, (typically family members) (NOSHEM)

(6) Other holdings: Entities outside one of the above categories (NOSHOF)

(7) Foreign block holders: Holdings by an institution domiciled in a country other than that of the issuer (NOSHFR)

Price

Book to Market Value

Traded Volume

Number of Shares

Worldwide governance indicators Voice and Accountability

Political Stability and Absence of Violence/ Terrorism
This is the adjusted default official daily closing price. It is denominated in primary units of local currency. Prices are generally based on 'last trade' or an official price fixing. The 'current' prices taken at the close of market are stored each day. These stored prices are adjusted for subsequent capital actions, and this adjusted figure then becomes the default price available

This is defined as the inverse of the market value of the ordinary (common) equity divided by the balance sheet value of the ordinary (common) equity in the company (Worldscope item 03501) which is available through Datastream

This shows the number of shares traded for a stock on a particular day. The data type is reported in thousands. Both daily and nondaily figures are adjusted for capital events. However, if a capital event occurs in the latest period of a non-daily request, then the volume for that particular period only is retrieved as unadjusted.

This is the total number of ordinary shares that represent the capital NOSH of the company. The data type is expressed in thousands.

This captures perceptions of the extent to which a country's citizens -- -are able to participate in selecting their government, as well as freedom of expression, freedom of association, and a free media

This measures perceptions of the likelihood that the government -- -will be destabilized or overthrown by unconstitutional or violent means, including politically-motivated violence and terrorism. 
Government Effectiveness

Regulatory Quality

Rule of Law

Control of Corruption
This captures perceptions of the quality of public services, the quality of the civil service and the degree of its independence from political pressures, the quality of policy formulation and implementation, and the credibility of the government's commitment to such policies

This captures perceptions of the ability of the government to -- -formulate and implement sound policies and regulations that permit and promote private sector development.

This captures perceptions of the extent to which agents have confidence in and abide by the rules of society, and in particular the quality of contract enforcement, property rights, the police, and the courts, as well as the likelihood of crime and violence.

This captures perceptions of the extent to which a country's citizens -- -are able to participate in selecting their government, as well as freedom of expression, freedom of association, and a free media 
Appendix C Table 1C. ASSET4-ESG governance element detailed definitions

This provides a detailed definition of all ASSET4 governance elements used in study

Variable
Board composition
Board diversity policy
Adequate experience of board policy

Board independence policy

Board size policy

CEO board member

Chairman is ex-CEO

Nomination committee

Succession plan for executives

Corporate governance committee

External consultants

\section{Definition}

Boards of directors with greater diversity amongst their directors draw on more breadth of experience and hence resources. Greater diversity also implies less dictatorial power arising from potential unchecked domination of board affairs by $\mathrm{CEO}$

Company policies regarding a guarantee of adequate experience of board members acts to ensure that directors have sufficient social competencies and can bring resources in form of human and social capital networks to board. These act as a check and balance to power exercised by dominant CEO

Company policy regarding guaranteed independence of its board provides the basis of an effective power check on dictatorial power of dominant insiders and CEO. Independent directors are independent of being subverted by dominant insider groups caused by their having exclusively been hired, or their pay, or contractual terms and conditions being determined by insiders. Thus, independent directors are more effectively able to question company strategy

Policy regarding board size relates to larger sized boards being associated with being more democratized in the sense of drawing on greater numbers of directors. This has been associated with more resources on one hand but questionable coordination and communication efficiencies

The CEO being a board member is indicative of the CEO having a formally mandated director position - either on unitary board or the supervisory board of a dual-tier board governance system prevalent in continental European modes of governance. Thus, the CEO has considerable potential power over board affairs

If the Chairperson is the former CEO then this potentially subverts the independent monitoring capability of the Chairperson over the strategic decision making of the CEO. While the chairperson should ideally be of similar social stature and experience to the CEO, the career progression of the company's CEO into that position potentially weakens monitoring capacity of the nonexecutive directors

A nomination committee is a dedicated instrument responsible for the hiring and appraisal of executive directors. Nonexecutive directors have oversight of the committee while its establishment implies that dominant insiders or CEO do not have so much influence or subversion over recruitment process which ultimately leads to subversion of internal leadership within company

A succession plan implies a smooth transfer of power should executives leave and avoid potential instability or "power vacuums" arising from rapid departures. Such instability can lead to subversion by powerful insiders or CEO

A corporate governance committee is dedicated to ensuring optimal governance to enhance outside minority shareholder property rights with respect to potential infringements by insiders. As such it has fidicuiary responsibility over audit, control and governance structure of firm

External consultants working on accounting and audit for the company are independent and provide evaluations independent from subversion by insider groups or CEO. Thus, they enhance transparency and accountability of insiders 
Golden parachute

Limitation of director liability

Limitations on removal of directors

Limited shareholder rights to call meetings

Majority requirements for election of directors

Poison pill

\section{Voting}

Equal voting right policy

Shareholder engagement policy

Pre-emptive rights

Public availability corporate statutes
Golden parachutes are a governance element linked to anti-takeover defences. These are structured severance packages for incumbent executives and can be used to prevent or delay hostile takeovers that would otherwise initiate management restructuring and potentially enhance outside minority shareholder value. Thus, golden parachutes act to enhance insider and CEO dominance and dictatorial power

This refers to a limitation on individual director's legal liability for their actions - if these are contrary to their fidicuiary responsibility and outside minority shareholder interests. Thus, these enhance dictatorial power of insiders and CEO through a decrease in their accountability

Limitations on removal of individual directors acts to reduce shareholder rights and therefore enhances the dictatorial power of insiders and CEO

Limitations on shareholder rights to call extraordinary general meetings to discuss an event is a direct reduction in property rights of minority outside owners and their control over insiders groups power and firm's internal affairs

This refers to a majority of shareholders required to nominate or elect individual directors. This can be used to reduce shareholders democratic property rights

Poison pills are representative of a number of governance elements designed to demotivate hostile takeovers that would otherwise initiate comprehensive managerial restructuring - where this is deemed to enhance minority shareholder value. Thus, poison pills are associated with enhancing insider and CEO power at the expense of minority democratic shareholder rights

One share - one vote is a fundamental principle in shareholder rights. Deviations from this include multiple class shares and the issuance of shares with different voting rights

Shareholder engagement is the process by which a company involves minority outside shareholders who may be affected by the decisions it makes, or can influence the implementation of its decisions. They may support or oppose the decisions, be influential in the organization or within the community in which it operates, hold relevant official positions or be affected in the long term

A pre-emptive right is a privilege that may be extended to certain shareholders of a corporation that grants them the right to purchase additional shares in the company prior to shares being made available for purchase by the general public in the event of a seasoned offering, which is a secondary issuing of stock shares. A pre-emptive right, also referred to as pre-emption rights, anti-dilution provisions or subscription rights, is written into the contract between the stock purchaser and the company, although a few states grant pre-emptive rights as a matter of law unless specifically negated in a company's articles of incorporation. A pre-emptive right does not function like a put option that gives a shareholder the right to sell stock at a specified price

This refers to the universal public availability of the company's articles of association, statutes or bylaws - where these can potentially be used by outside minority shareholders as proof of defamations to their property rights in the event of infringements by dominant insiders and CEO. As such it focusses on transparency of information property rights of shareholders 
Advance notice for shareholder proposals

Confidential voting policy

Different share classes different rights

Elimination of cumulative voting rights

Expanded constituency provision

Fair price provision

Min. number of shares to vote

Voting cap

Significant company transactions (M\&A) shareholder's approval

Supermajority vote requirements

Written consent requirements

Integrated strategy in MD\&A

\section{Delay}

Classified board structure

Staggered board structure

Company cross shareholding

Golden share
This relates to the company having deadlines relating to shareholder proposals

This refers to confidentiality in the shareholder voting - where incumbent management cannot view results of voting nor how individual shareholders voted.

This refers to the company having different class stocks with different voting rights

This refers to whether the company reduced or eliminated cumulative voting in regard to the election of board members

A constituency statute, also called a stakeholder statute, allows corporate directors to consider non-shareholder interests when making business decisions

State law or a bylaw of a corporation's charter that compels a bidder for the corporation's majority stock to pay at least the fair market price for the stock held by minority stockholders

This refers to the company setting requirements for a minimum number of shares to vote

This refers to the company having shares with a voting cap (ceilings) clause, ownership ceilings or control share acquisition provision

This refers to limitations to the shareholders right to approve significant company transitions such as M\&As (no rights to vote or supermajority required)

This refers to the company having a supermajority vote requirement or qualified majority (for amendments of charters and bylaws or lock-in provisions)

This refers to the company permitting actions to be taken without meeting by written consent

This refers to the company explicitly integrating financial and extra-financial factors in its management discussion and analysis (MD\&A) section in the annual report. This facilitates transparency in communication to minority outside shareholders

A structure for a board of directors in which a portion of the directors serve for different term lengths, depending on their particular classification. Under a classified system, directors serve terms usually lasting between one and eight years; longer terms are often awarded to more senior board positions (i.e. chairman of the corporate governance committee)

A staggered board consists of a board of directors whose members are grouped into classes; for example, Class 1, Class 2, Class 3, etc. Each class represents a certain percentage of the total number of board positions. For example, a class is commonly comprised on one-third of the total board members. During each election term only one class is open to elections, thereby staggering the board directorship

This refers to company having significant cross shareholdings amongst other firms that can prevent takeovers

This refers to the biggest owner (by voting power) holding veto power which is also referred to as owing golden shares 
Blank check

State owned enterprise

\section{Director Incentives}

Shareholder's approval of stock based compensation Plan

CEO compensation link to shareholder return

Compensation committee

Compensation improvement tools

Executive retention compensation policy

Performance oriented compensation policy

Shareholders vote on executive pay
A method companies use to simplify the process of creating new classes of preferred stock is to raise additional funds from sophisticated investors without obtaining separate shareholder approval

This refers to whether the company a State Owned Enterprise (SOE) where state control is vexed over minority outside shareholders

This refers to formal shareholder approval being required before the initiation of stock-based compensation plans for incumbent insiders, executives and CEO

This refers to whether the CEO's compensation is directly linked to minority outside shareholder welfare or return. This amounts to a democratization of CEO compensation whereby insiders are inhibited in self-award tendencies at the expense of minority shareholders

This refers to the establishment of a dedicated committee staffed by nonexecutive directors who appraise executive directors and award their compensation plans. The committee also has responsibility for the structure of their compensation. The presence of such a committee inhibits incumbent insider director tendencies for self-award at the expense of shareholder welfare which is a form of appropriation

This refers to the company having the necessary internal improvement and information tools for the board members to develop appropriate compensation/remuneration to attract and retain key executives

This refers to the company having a compensation policy that is geared to competitively attracting and retaining executives in the managerial labour market through appropriately designed rewards

This refers to executive compensation being linked to company performance and hence ultimately shareholder welfare. This inhibits insider self-reward tendencies and appropriation

This refers to whether the company's shareholders have the right to vote on executive compensation 


\section{Appendix D. Table 1D. Empirical models}

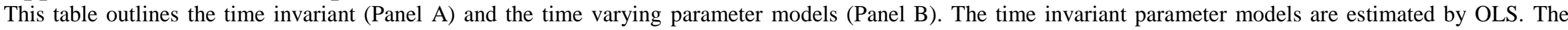

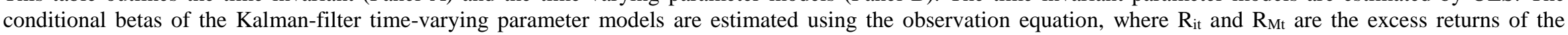

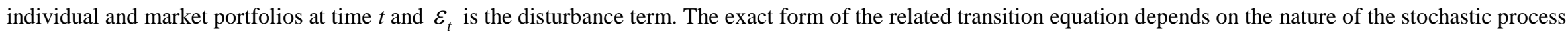

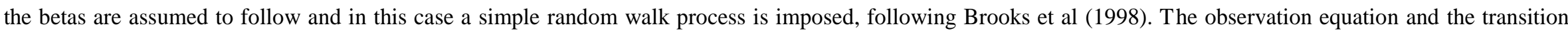

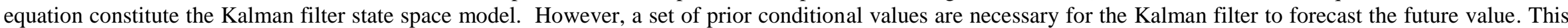

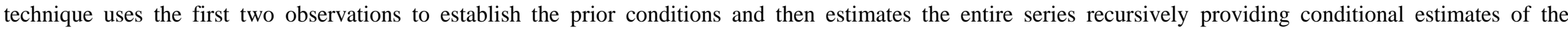

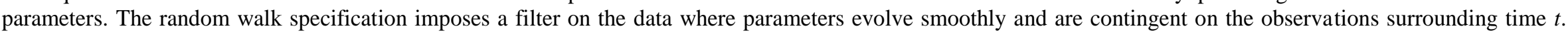

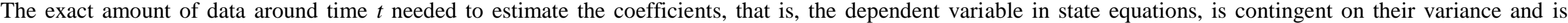

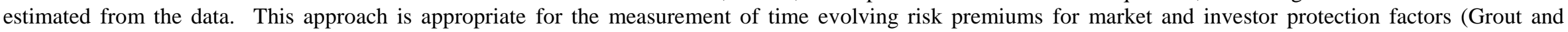
Zalewska, 2006). Thus, one-step ahead predicted states and their associated standard errors are estimated for all FMPs.

\begin{tabular}{|c|c|}
\hline Panel A: Time invariant parameter models & Panel B:Time varying parameter models \\
\hline $\begin{array}{l}\text { Model 1a: CAPM } \\
\text { The standard CAPM can be estimated by OLS regression: } \\
r_{p t}-r_{f t}=\alpha_{i}+\beta_{M}\left(r_{m t}-r_{f t}\right)+\varepsilon_{i t}\end{array}$ & $\begin{array}{l}\text { Model 1b: CAPM } \\
\text { The conditional betas are estimated using the following observation equation: } \\
R_{i t}=\alpha_{t}+\beta_{i t}^{\text {Kalman }} R_{M t}+\varepsilon_{t}, \quad \varepsilon_{t} \sim N(0, \Omega) \\
\text { The corresponding transition equation is defined: } \\
\alpha_{i t}^{\text {Kalman }}=\alpha_{i t-1}^{\text {Kalman }}+\eta_{\alpha t,} \quad \eta_{\alpha t} \sim N(0, Q) \\
\beta_{i t}^{\text {Kalman }}=\beta_{i t-1}^{\text {Kalman }}+\eta_{\beta t}, \quad \eta_{\beta t} \sim N(0, Q) \\
\text { with a set of prior conditional values: } \\
\alpha_{0}^{\text {Kalman }} \sim N\left(\alpha_{0}^{\text {Kalman }}, P_{0}\right) \\
\beta_{0}^{\text {Kalman }} \sim N\left(\beta_{0}^{\text {Kalman }}, P_{0}\right)\end{array}$ \\
\hline $\begin{array}{l}\text { Model 2a: FF3F } \\
\text { Following Fama and French (1993), additional SMB and HML terms are the } \\
\text { size and book-to-market factors and estimated by OLS regression: } \\
r_{p t}-r_{f t}=\alpha_{i}+\beta_{M}\left(r_{m t}-r_{f t}\right)+\beta_{S M B} S M B_{t}+\beta_{H M L} H M L_{t}+\varepsilon_{i t}\end{array}$ & $\begin{array}{l}\text { Model 2b: FF3F } \\
\text { The conditional betas are estimated using the following observation equation: } \\
R_{i t}=\alpha_{t}+\beta_{i t}^{\text {Kalman }} R_{M t}+s_{i}^{\text {Kalman }} S M B+h_{i}^{\text {Kalman }} H M L+\varepsilon_{t}, \quad \varepsilon_{t} \sim N(0, \Omega) \\
\text { The corresponding transition equation is defined: } \\
\alpha_{i t}^{\text {Kalman }}=\alpha_{i t-1}^{\text {Kalman }}+\eta_{\alpha t,} \quad \eta_{\alpha t} \sim N(0, Q) \\
\beta_{i t}^{\text {Kalman }}=\beta_{i t-1}^{\text {Kalman }}+\eta_{\beta t,} \quad \eta_{\beta t} \sim N(0, Q) \\
s_{i t}^{\text {Kalman }}=s_{i t-1}^{\text {Kalman }}+\eta_{s t,} \quad \eta_{s t} \sim N(0, Q) \\
h_{i t}^{\text {Kalman }}=h_{i t-1}^{\text {Kalman }}+\eta_{h t,} \quad \eta_{h t} \sim N(0, Q) \\
\text { with prior conditional values denoted by: } \\
\alpha_{0}^{\text {Kalman }} \sim N\left(\alpha_{0}^{\text {Kalman }}, P_{0}\right) \\
\beta_{0}^{\text {Kalman }} \sim N\left(\beta_{0}^{\text {Kalman }}, P_{0}\right) \\
s_{0}^{\text {Kalman }} \sim N\left(s_{0}^{\text {Kalman }}, P_{0}\right)\end{array}$ \\
\hline
\end{tabular}




\begin{tabular}{|c|c|}
\hline & $h_{0}^{\text {Kalman }} \sim N\left(h_{0}^{\text {Kalman }}, P_{0}\right)$ \\
\hline $\begin{array}{l}\text { Model 3a: Carhart 4F } \\
\text { Following Carhart (1997), we augment FF3F with the momentum term, } \\
\text { which is estimated by OLS regression: } \\
r_{p t}-r_{f t}=\alpha_{i}+\beta_{M}\left(r_{m t}-r_{f t}\right)+\beta_{S M B} S M B_{t}+\beta_{H M L} H M L_{t}+\beta_{M o m} M_{t}+\varepsilon_{i t}\end{array}$ & $\begin{array}{l}\text { Model 3b: Carhart 4F } \\
\text { The conditional betas are estimated using the following observation equation: } \\
R_{i t}=\alpha_{t}+\beta_{i t}^{\text {Kalman }} R_{M t}+s_{i}{ }^{\text {Kalman }} S M B+h_{i}^{\text {Kalman }} H M L+m_{i}^{\text {Kalman }} M o m+\varepsilon_{t}, \\
\varepsilon_{t} \sim N(0, \Omega) \\
\text { The corresponding transition equation is defined: } \\
\alpha_{i t}^{\text {Kalman }}=\alpha_{i t-1}^{\text {Kalman }}+\eta_{\alpha t,} \quad \eta_{o t} \sim N(0, Q) \\
\beta_{i t}^{\text {Kalman }}=\beta_{i t-1}^{\text {Kalman }}+\eta_{\beta t,}, \quad \eta_{\beta t} \sim N(0, Q) \\
s_{i t}^{\text {Kalman }}=s_{i t-1}^{\text {Kalman }}+\eta_{s t,} \quad \eta_{s t} \sim N(0, Q) \\
h_{i t}^{\text {Kalman }}=h_{i t-1}^{\text {Kalman }}+\eta_{h t,} \quad \eta_{h t} \sim N(0, Q) \\
m_{i t}^{\text {Kalman }}=m_{i t-1}^{\text {Kalman }}+\eta_{h t,} \quad \eta_{h t} \sim N(0, Q) \\
\text { with prior conditional values denoted by: } \\
\alpha_{0}^{\text {Kalman }} \sim N\left(\alpha_{0}^{\text {Kalman }}, P_{0}\right) \\
\beta_{0}^{\text {Kalman }} \sim N\left(\beta_{0}^{\text {Kalman }}, P_{0}\right) \\
s_{0}^{\text {Kalman }} \sim N\left(s_{0}^{\text {Kalman }}, P_{0}\right) \\
h_{0}^{\text {Kalman }} \sim N\left(h_{0}^{\text {Kalman }}, P_{0}\right) \\
m_{0}^{\text {Kalman }} \sim N\left(m_{0}^{\text {Kalman }}, P_{0}\right)\end{array}$ \\
\hline $\begin{array}{l}\text { Model 4a: Liquidity } \mathbf{2 F} \\
\text { Liu (2006) introduces a two-factor liquidity model, which is estimated by } \\
\text { OLS regression: } \\
r_{i t}-r_{f t}=\alpha_{i}+\beta_{i}\left(r_{m t}-r_{f t}\right)+\beta_{I l l i q} I L L I Q_{t}+\varepsilon_{i t} \\
\text { We use two versions of the investor protection factor, created from the two } \\
\text { rebalancing methods, monthly and annual, both with annual holding periods. }\end{array}$ & $\begin{array}{l}\text { Model 4b: Liquidity } \mathbf{2 F} \\
\text { The conditional betas are estimated using following the observation equation: } \\
R_{i t}=\alpha_{t}+\beta_{i t}^{\text {Kalman }} R_{M t}+z_{i}^{\text {Kalman }} I L L I Q+\varepsilon_{t}, \quad \varepsilon_{t} \sim N(0, \Omega) \\
\text { The corresponding transition equation is defined: } \\
\alpha_{i t}^{\text {Kalman }}=\alpha_{i t-1}^{\text {Kalman }}+\eta_{\alpha t,} \quad \eta_{\alpha t} \sim N(0, Q) \\
\beta_{i t}^{\text {Kalman }}=\beta_{i t-1}^{\text {Kalman }}+\eta_{\beta t,} \quad \eta_{\beta t} \sim N(0, Q) \\
z_{i t}^{\text {Kalman }}=z_{i t-1}^{\text {Kalman }}+\eta_{h t,} \quad \eta_{h t} \sim N(0, Q) \\
\text { with prior conditional values denoted by: } \\
\alpha_{0}^{\text {Kalman }} \sim N\left(\alpha_{0}^{\text {Kalman }}, P_{0}\right) \\
\beta_{0}^{\text {Kalman }} \sim N\left(\beta_{0}^{\text {Kalman }}, P_{0}\right) \\
z_{0}^{\text {Kalman }} \sim N\left(z_{0}^{\text {Kalman }}, P_{0}\right)\end{array}$ \\
\hline $\begin{array}{l}\text { Model 5a: Investor Protection 2F } \\
\text { A two-factor CAPM augmented with the new investor protection factor to } \\
\text { account for institutional differences across international markets is proposed }\end{array}$ & $\begin{array}{l}\text { Model 5b: Investor Protection 2F } \\
\text { The conditional betas are estimated using the following observation equation }\end{array}$ \\
\hline
\end{tabular}


and can be stated

$E\left(r_{p t}\right)-r_{f t}=\beta_{M}\left[E\left(r_{m t}\right)-r_{f t}\right]+\beta_{\text {INV-PROTECT }} E(I N V-P R O T E C T)$

where $r_{p t}$ is the returns on a portfolio $\mathrm{p}$ of stocks at time interval $\mathrm{t}, r_{m t}$ is the returns on the market portfolio and $r_{f t}$ the risk free rate. INV-PROTECT is the investor protection factor. This can be rearranged and estimated by OLS regression

$r_{p t}-r_{f t}=\alpha_{i}+\beta_{M}\left(r_{m t}-r_{f t}\right)+\beta_{I N V-P R O T E C T} I N V-P R O T E C T_{t}+\varepsilon_{i t}$

where $\alpha_{i}$ is the constant, $\beta_{M}$ is the market coefficient and $\varepsilon_{i t}$ is an iid disturbance term. We use two versions of the investor protection factor, created from the two rebalancing methods, monthly and annual, both with annual holding periods.

\section{Model 6a: Governance 2F}

A two-factor CAPM augmented with the new governance factor to account for institutional differences across international markets is proposed and can be stated

$E\left(r_{p t}\right)-r_{f t}=\beta_{M}\left[E\left(r_{m t}\right)-r_{f t}\right]+\beta_{\text {GOVERNANCE }} E(G O V E R N A N C E)$

where $r_{p t}$ is the returns on a portfolio $\mathrm{p}$ of stocks at time interval $\mathrm{t}, r_{m t}$ is the returns on the market portfolio and $r_{f t}$ the risk free rate. GOVERNANCE is the governance factor. This can be rearranged and estimated by OLS regression

$r_{p t}-r_{f t}=\alpha_{i}+\beta_{M}\left(r_{m t}-r_{f t}\right)+\beta_{\text {GOVERNANCE }}$ GOVERNANCE $t_{t}+\varepsilon_{i t} \mathrm{w}$

here $\alpha_{i}$ is the constant, $\beta_{M}$ is the market coefficient and $\varepsilon_{i t}$ is an iid

disturbance term. We use two versions of the governance factor, created from the two rebalancing methods, monthly and annual, both with annual holding periods.
$R_{i t}=\alpha_{t}+\beta_{i t}^{\text {Kalman }} R_{M t}+\beta_{\text {INV-PROTECTit }}^{\text {Kalman }}($ INV - PROTECT $)+\varepsilon_{t}, \quad \varepsilon_{t} \sim N(0, \Omega)$

The corresponding transition equation is defined:

$\alpha_{i t}^{\text {Kalman }}=\alpha_{i t-1}^{\text {Kalman }}+\eta_{\alpha t,} \quad \eta_{\alpha t} \sim N(0, Q)$

$\beta_{i t}^{\text {Kalman }}=\beta_{i t-1}^{\text {Kalman }}+\eta_{\beta t,} \quad \eta_{\beta t} \sim N(0, Q)$

$\beta_{\text {INV-PROTECTit }}^{\text {Kalman }}=\beta_{\text {INV-PROTECTit }-1}^{\text {Kalman }}+\eta_{\text {st },} \quad \eta_{s t} \sim N(0, Q)$

with prior conditional values denoted by:

$\alpha_{0}^{\text {Kalman }} \sim N\left(\alpha_{0}^{\text {Kalman }}, P_{0}\right)$

$\beta_{0}^{\text {Kalman }} \sim N\left(\beta_{0}^{\text {Kalman }}, P_{0}\right)$

$\beta_{\text {INV-PROTECT0 }}^{\text {Kalman }} \sim N\left(\beta_{\text {INV-PROTECT 0 }}^{\text {Kalman }}, P_{0}\right)$

\section{Model 6b: Governance 2F}

The conditional betas are estimated using the following observation equation $R_{i t}=\alpha_{t}+\beta_{i t}^{\text {Kalman }} R_{M t}+\beta_{\text {GOVERNANCEit }}{ }^{\text {Kalman }}(G O V E R N A N C E)+\varepsilon_{t}, \quad \varepsilon_{t} \sim N(0, \Omega)$

The corresponding transition equation is defined:

$\alpha_{i t}^{\text {Kalman }}=\alpha_{i t-1}^{\text {Kalman }}+\eta_{\alpha t,} \quad \eta_{\alpha t} \sim N(0, Q)$

$\beta_{i t}^{\text {Kalman }}=\beta_{i t-1}^{\text {Kalman }}+\eta_{\beta t,} \quad \eta_{\beta t} \sim N(0, Q)$

$\beta_{\text {GOVERNANCEit }}^{\text {Kalman }}=\beta_{\text {GOVERNANCEit }-1}^{\text {Kalman }}+\eta_{\text {st },} \quad \eta_{s t} \sim N(0, Q)$

with prior conditional values denoted by:

$\alpha_{0}^{\text {Kalman }} \sim N\left(\alpha_{0}^{\text {Kalman }}, P_{0}\right)$

$\beta_{0}^{\text {Kalman }} \sim N\left(\beta_{0}^{\text {Kalman }}, P_{0}\right)$

$\beta_{\text {GOVERNANCEO }}^{\text {Kalman }} \sim N\left(\beta_{\text {GOVERNANCE } 0}^{\text {Kalman }}, P_{0}\right)$ 


\section{Appendix E. Block owner categories per governance sorted decile}

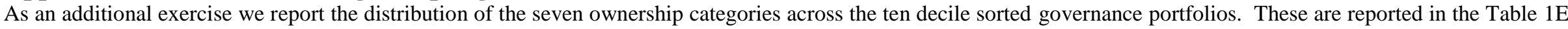

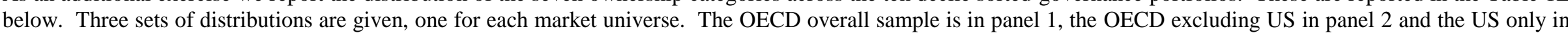

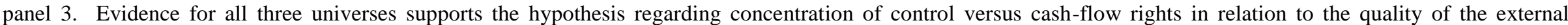

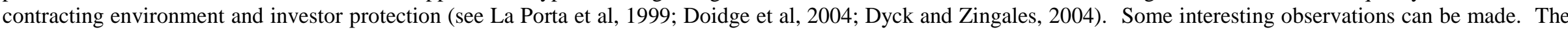

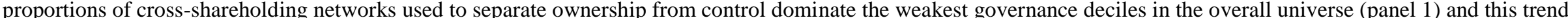

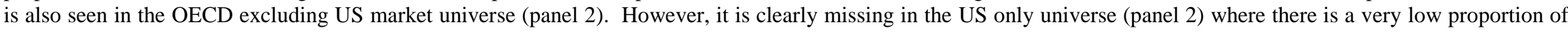

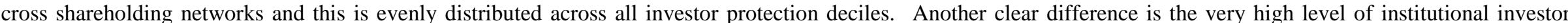

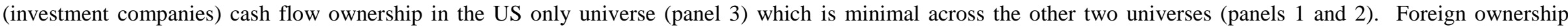

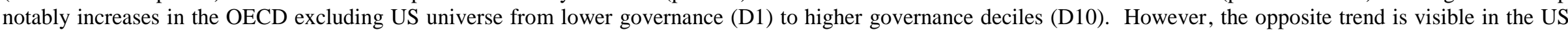

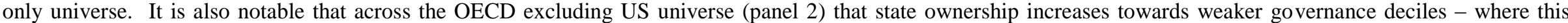
category of owner is almost non-existent in US only universe.

\section{Table 1E. Block owner categories per governance sorted decile}

The second panel provides details of block shareholders per decile-sorted governance portfolio by category. Datastream categorizes block holders into seven types: crossshareholder networks, employee/family, foreign, state, institutional investor, other, and pension funds. Categories of block shareholder are from Datastream.

\begin{tabular}{|c|c|c|c|c|c|c|c|c|c|c|}
\hline \multicolumn{11}{|l|}{ Block owners (\%) } \\
\hline Panel 1: OECD universe & D1 & D2 & D3 & D4 & D5 & D6 & D7 & D8 & D9 & D10 \\
\hline Cross-shareholder networks & 30.90 & 5.66 & 4.48 & 5.18 & 16.28 & 25.91 & 15.85 & 24.29 & 22.08 & 13.53 \\
\hline Employee/ Family & 12.57 & 9.85 & 6.17 & 6.67 & 12.04 & 16.80 & 9.43 & 23.40 & 15.00 & 11.59 \\
\hline Foreign & 12.06 & 3.39 & 2.56 & 6.72 & 13.12 & 11.39 & 5.66 & 11.81 & 10.97 & 11.66 \\
\hline State & 1.16 & 0.20 & 0.09 & 0.63 & 2.40 & 3.82 & 0.53 & 2.67 & 2.81 & 0.99 \\
\hline Investment companies & 11.97 & 21.04 & 20.64 & 19.28 & 11.33 & 8.59 & 6.41 & 7.03 & 8.94 & 9.75 \\
\hline Other & 2.62 & 2.68 & 2.12 & 2.47 & 6.62 & 8.87 & 3.81 & 14.17 & 9.95 & 3.35 \\
\hline Pension Funds & 2.06 & 1.94 & 3.60 & 3.73 & 2.39 & 2.36 & 1.23 & 1.16 & 3.70 & 1.98 \\
\hline \multicolumn{11}{|c|}{ Panel 2: OECD (excl. US) universe } \\
\hline Cross-shareholder networks & 17.09 & 17.92 & 19.88 & 31.33 & 16.31 & 25.91 & 15.87 & 24.29 & 22.10 & 13.53 \\
\hline Employee/ Family & 11.40 & 11.90 & 9.28 & 15.04 & 12.05 & 16.79 & 9.43 & 23.41 & 15.02 & 11.59 \\
\hline Foreign & 6.88 & 10.12 & 7.41 & 17.35 & 13.14 & 11.40 & 5.69 & 11.80 & 10.97 & 11.66 \\
\hline State & 4.92 & 3.48 & 0.99 & 1.52 & 2.40 & 3.82 & 0.54 & 2.66 & 2.81 & 0.99 \\
\hline Investment companies & 9.43 & 5.40 & 8.02 & 9.23 & 11.33 & 8.59 & 6.41 & 7.04 & 8.93 & 9.75 \\
\hline Other & 3.78 & 5.16 & 11.58 & 3.51 & 6.63 & 8.88 & 3.81 & 14.17 & 9.95 & 3.35 \\
\hline Pension Funds & 4.15 & 2.04 & 2.82 & 2.54 & 2.39 & 2.36 & 1.22 & 1.15 & 3.69 & 1.98 \\
\hline \multicolumn{11}{|l|}{ Panel 3: US-only universe } \\
\hline Cross-shareholder networks & 3.67 & 4.84 & 3.76 & 3.52 & 1.85 & 2.00 & 0.28 & 6.69 & 4.47 & 3.84 \\
\hline Employee/ Family & 4.79 & 6.76 & 3.59 & 2.93 & 6.45 & 4.71 & 6.74 & 9.62 & 6.66 & 4.22 \\
\hline Foreign & 6.88 & 1.45 & 3.14 & 2.38 & 6.62 & 1.85 & 1.46 & 3.80 & 2.50 & 3.20 \\
\hline State & 0.30 & 0.00 & 0.00 & 0.48 & 1.43 & 0.00 & 0.71 & 0.13 & 0.08 & 0.42 \\
\hline Investment companies & 21.77 & 19.43 & 25.29 & 22.76 & 18.39 & 20.97 & 23.19 & 20.80 & 20.94 & 20.62 \\
\hline Other & 2.23 & 1.73 & 0.87 & 0.96 & 2.39 & 0.42 & 0.32 & 2.77 & 2.15 & 1.25 \\
\hline Pension Funds & 3.39 & 3.92 & 4.62 & 3.49 & 3.79 & 3.03 & 1.05 & 1.55 & 3.41 & 4.16 \\
\hline
\end{tabular}

